\title{
Evaluation of Daphnia ambigua for Routine Aquatic Toxicity Testing at the Savannah River Site
}

by

W. L. Specht

Westinghouse Savannah River Company

Savannah River Site

Aiken, South Carolina 29808

RECEVED

S. M. Harmon

University of South Carolina

SC USA

MAY 061998

OSTI

DOE Contract No. DE-AC09-89SR18035

This paper was prepared in connection with work done under the above contract number with the U.S.

Department of Energy. By acceptance of this paper, the publisher and/or recipient acknowledges the U.S. Government's right to retain a nonexclusive, royalty-free license in and to any copyright covering this paper, along with the right to reproduce and to authorize others to reproduce all or part of the copyrighted paper. 


\section{DISCLAIMER}

This report was prepared as an account of work sponsored by an agency of the United States Government. Neither the United States Government nor any agency thereof, nor any of their employees, makes any warranty, express or implied, or assumes any legal liability or responsibility for the accuracy, completeness, or usefulness of any information, apparatus, product, or process disclosed, or represents that its use would not infringe privately owned rights. Reference herein to any specific commercial product, process, or service by trade name, trademark, manufacturer, or otherwise does not necessarily constitute or imply its endorsement, recommendation, or favoring by the United States Government or any agency thereof. The views and opinions of authors expressed herein do not necessarily state or reflect those of the United States Government or any agency thereof.

This report has been reproduced directly from the best available copy.

Available to DOE and DOE contractors from the Office of Scientific and Technical Information, P.O. Box 62, Oak Ridge, TN 37831; prices available from (615) 576-8401.

Available to the public from the National Technical Information Service, U.S. Department of Commerce; 5285 Port Royal Road, Springfield, VA 22161. 


\section{DISCLAIMER}

Portions of this document may be illegible electronic image products. Images are produced from the best available original document. 


\title{
EVALUATION OF Daphnia ambigua FOR ROUTINE AQUATIC TOXICITY TESTING AT THE SAVANNAH RIVER SITE (U)
}

\author{
by \\ WINONA L. SPECHT \\ SAVANNAH RIVER TECHNOLOGY CENTER \\ and \\ S. MICHELE HARMON \\ UNIVERSITY OF SOUTH CAROLINA
}

Approved by:

\author{
DBmore=Shedurs \\ D.B. Moore-Shedrow, Department Manager \\ Environmental Sciences and Technology Department \\ Savannah River Technology Center
}

Publication Date: $\quad$ September 1997

WESTINGHOUSE SAVANNAH RIVER COMPANY

SAVANNAH RIVER SITE

AIKEN, SC 29808

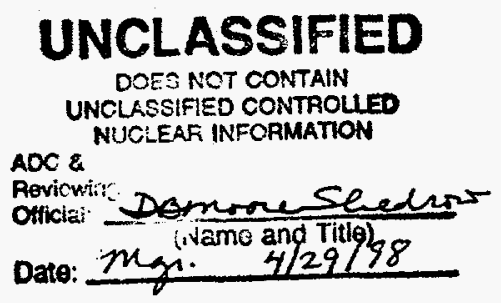

THIS DOCUMENT WAS PREPARED IN CONNECTION WTTH WORK UNDER U.S. DEPARTMENT OF ENERGY CONTRACT DE-AC09-89SR18035. By acceptance of this paper, the publisher and/or recipient acknowledges the U.S. Government's right to retain a nonexclusive, royalty-free license in and to any copyright covering this paper, along with the right to reproduce and to authorize others to reproduce all or any part of the copyrighted paper. 


\section{TABLE OF CONTENTS}

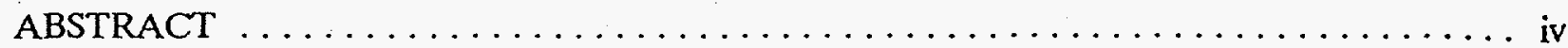

INTRODUCTION $\ldots \ldots \ldots \ldots \ldots \ldots \ldots \ldots \ldots \ldots \ldots \ldots \ldots \ldots \ldots \ldots \ldots$

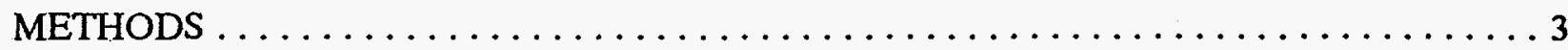

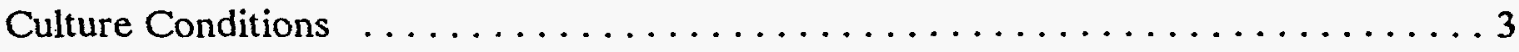

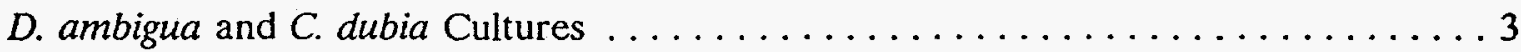

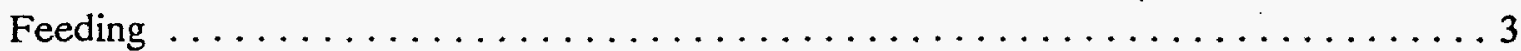

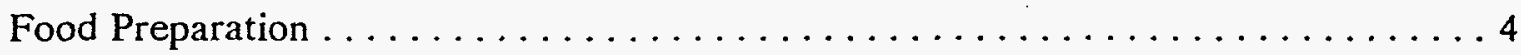

TOXICITY TESTING $\ldots \ldots \ldots \ldots \ldots \ldots \ldots \ldots \ldots \ldots \ldots \ldots \ldots \ldots \ldots$

Phase I - Sensitivity Comparison $\ldots \ldots \ldots \ldots \ldots \ldots \ldots \ldots \ldots \ldots \ldots \ldots \ldots \ldots \ldots \ldots \ldots \ldots \ldots$

Test Compounds and Analytical Methods $\ldots \ldots \ldots \ldots \ldots \ldots \ldots \ldots \ldots \ldots$

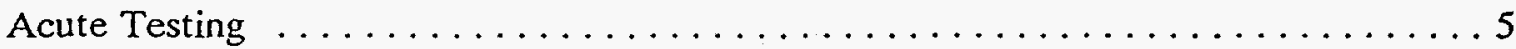

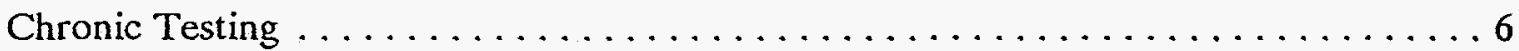

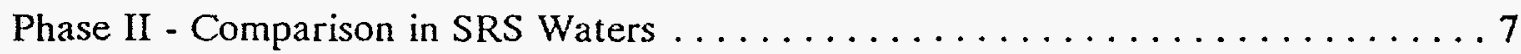

Stream Water Reproductive Success Comparison $\ldots \ldots \ldots \ldots \ldots \ldots \ldots$

Acute Stream Water Comparison $\ldots \ldots \ldots \ldots \ldots \ldots \ldots \ldots \ldots \ldots \ldots$

RESULTS AND DISCUSSION $\ldots \ldots \ldots \ldots \ldots \ldots \ldots \ldots \ldots \ldots \ldots \ldots \ldots$

Phase I - Sensitivity Comparison $\ldots \ldots \ldots \ldots \ldots \ldots \ldots \ldots \ldots \ldots \ldots \ldots \ldots \ldots \ldots$

Phase II - Species Comparison in SRS Waters . . . . . . . . . . . . 14

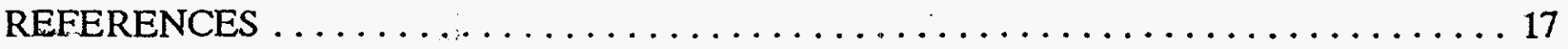




\section{LIST OF TABLES}

Table 1. Summary of analytical measurements conducted on test solutions during 48-hour

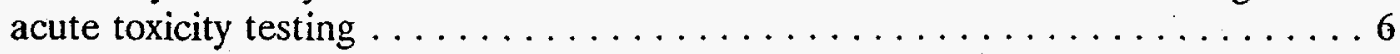

Table 2. Forty-eight hour $\mathrm{LC}_{50}$ values for $D$. ambigua and $C$. dubia exposed to sodium chloride, sodium lauryl sulfate, copper, and chlorpyrifos . . . . . . . . 10

Table 3. Summary of the 3-brood chronic toxicity tests with $C$. dubia and D. ambigua when exposed to sodium chloride and copper sulfate $\ldots \ldots \ldots \ldots \ldots \ldots \ldots \ldots$

Table 4. Results of chronic 3-brood toxicity with Ceriodaphnia dubia in

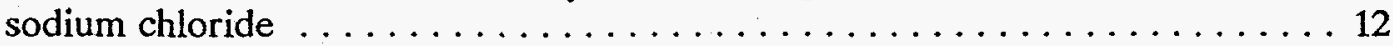

Table 5. Results of chronic 3-brood toxicity test with Daphnia ambigua in

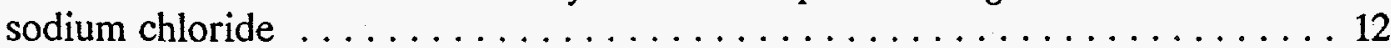

Table 6. Results of chronic 3-brood toxicity with Ceriodaphnia dubia in

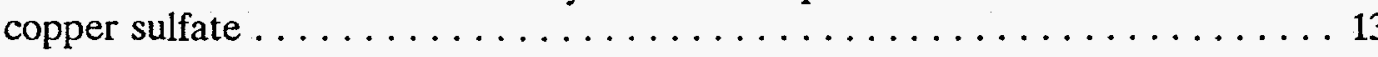

Table 7. Results of chronic 3-brood toxicity test with Daphnia ambigua in copper sulfate . . . . . . . . . . . . . . . . . 13

Table 8. Results of the 3-brood stream water reproductive success study performed with laboratory water and surface water from three streams on SRS . . . . . . . 14

Table 9. Summary of water quality parameters measured on daily renewal solutions for the

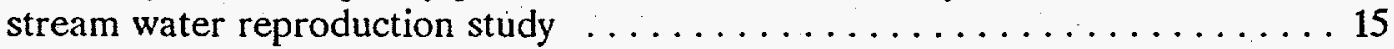

Table 10. Forty-eight hour toxicity test results for $D$. ambigua and $C$. dubia exposed to sodium chloride using water from three SRS streams as a diluent $\ldots \ldots \ldots \ldots \ldots$ 


\begin{abstract}
Short-term whole effluent toxicity testing, which is currently a requirement of the U.S. EPA's National Pollutant Discharge Elimination System (NPDES), commonly uses the cladoceran species Ceriodaphnia dubia. Despite the advantages to using a common test species to model the toxic effects of effluents, it could be argued that toxicity test results would be more meaningful if a wider variety of test organisms were commonly used. One particular argument against $C$. dubia is that tests conducted with this species do not always reflect local, site-specific conditions. The careful selection and use of an indigenous test species would produce a more realistic model of local instream effects and would account for regional differences in water quality.
\end{abstract}

Permitted effluent discharges from Savannah River Site (SRS), a government weapons facility operated by the U.S. Department of Energy, require toxicity testing with $C$. dubia. However, water quality in these receiving streams is markedly different (lower $\mathrm{pH}$ and hardness) from standard laboratory water used for the culturing and testing of $C$. dubia, and it has been shown that this receiving water presents varying degrees of toxicity to $C$. dubia. Based on these results, it is possible that toxic effects observed during an effluent study could be the result of test organism stress from the dilution water and not the effects of SRS effluents. Therefore, this study addressed the substitution of $C$. dubia with an indigenous cladoceran species, Daphnia ambigua for routine regulatory testing at SRS. Given the indigenous nature of this species, combined with the fact that it has been successfully cultured by other investigators, $D$. ambigua was ideal for consideration as a replacement for $C$. dubia, but further study of the overall success and sensitivity of laboratory-reared $D$. ambigua was required.

This investigation determined that $D$. ambigua could be laboratory cultured with only minimal changes to established regulatory protocol and that the life-cycle characteristics of this species were conducive to traditional acute and chronic aquatic toxicity test methods. Acute toxicity tests showed that when comparing $\mathrm{LC}_{50}$ values for $C$. dubia and $D$. ambigua, D. ambigua was less sensitive to some toxicants (sodium chloride, copper sulfate, and sodium lauryl sulfate) while more sensitive to others (chlorpyrifos). Results of chronic tests with copper sulfate and sodium chloride resulted in the same NOEC/LOEC values for both species. When exposed to unaltered SRS stream water, $C$. dubia demonstrated a "toxic" response for two of the three streams tested, while reproduction for D. ambigua was higher in all stream samples. Acute toxicity tests with sodium chloride in stream water, generally followed the sensitivity trend noted in tests conducted with regular laboratory water. 


\section{INTRODUCTION}

Federal legislation explicitly states that the discharge of toxic substances in toxic amounts is to be prohibited; therefore, the detection of toxic effects plays an important role in identifying and controlling toxic discharges to surface waters (USEPA, 1994). Since it is not economically feasible to determine the toxicity of each of the thousands of potentially toxic substances in complex effluents or to conduct exhaustive chemical analyses of effluents, the most direct and cost-effective approach is to conduct short-term whole effluent toxicity tests with aquatic organisms (USEPA, 1993). The objective of these tests is to provide a toxicity model which will estimate the "safe" or "no effect" concentration of the effluent (i.e., the concentration which will permit normal survival and propagation of aquatic life in the receiving waters).

Short-term whole effluent toxicity testing, which is currently a requirement of the U.S. EPA's National Pollutant Discharge Elimination System (NPDES), generally follows several standard protocols (USEPA, 1994; ASTM, 1993a,b) which include a description of the culture and use of the common cladoceran species Ceriodaphnia dubia. C. dubia are favored by EPA because this species is easily cultured in the laboratory and extensive data are available on the concentrationresponse model provided by this species (LaPoint et al., 1995).

Despite the advantages of using this popular test species, it could be argued that toxicity test results would be more meaningful if a wider variety of test organisms were commonly used. The selection of an appropriate test species is necessary for a realistic representation of the concentration-response relationship in an impacted stream. Rand and Petrocelli (1985) have suggested the following criteria for selection of an ideal aquatic toxicity test organism:

- the test species should.represent a broad range of sensitivities;

- the test species should be widely available and abundant;

- the test species should be indigenous to or representative of the ecosystem receiving the impact;

- the test species should be recreationally, commercially, or ecologically important;

- the test species should be amenable to routine maintenance in the laboratory and techniques should be available for culturing;

- there should be adequate background information on a test species so that test data may be more easily interpreted.

While ubiquitous use of $C$. dubia fills most of the above criteria, tests conducted with this species do not always reflect local, site-specific conditions. The careful selection and use of an indigenous test species would produce a more realistic model of local instream effects and would account for regional differences in water quality, such as the very soft waters of the southeastern United States where C. dubia are not abundant.

The NPDES permit for Savannah River Site (SRS) requires toxicity testing using $C$. dubia at numerous outfalls on several receiving streams. However, water quality in these receiving streams is markedly different from standard laboratory water used for the culturing and testing of $C$. dubia. Receiving stream waters on SRS are very soft $\left(<20 \mathrm{mg} / \mathrm{L}\right.$ as $\left.\mathrm{CaCO}_{3}\right)$ and have relatively low $\mathrm{pH}$ values. Studies to determine if unimpacted receiving stream water from three onsite streams would support $C$. dubia have shown that the stream water itself shows varying degrees of toxicity to this species (Specht, 1994). Based on these results, it is possible that 
toxicity observed during a chronic study could be the result of toxicity from the dilution water and not the effects of SRS effluents. Therefore, this study addressed the development of a toxicity test using a local, site-specific aquatic species which was presumed to be more suited for testing on the SRS and other facilities in the southeastern United States.

Daphnia ambigua was considered an ideal candidate as a site-specific test organism for routine NPDES toxicity testing at SRS. It is commonly found in waters of the southeastern United States and is abundant in waters of SRS. Hanazato (1990) has reported the maintenance of $D$. ambigua in laboratory cultures for more than five years, and a study performed by LaPoint et al. (1995) determined that $D$. ambigua can be cultured in very soft waters. However, further study of the overall success and sensitivity of this species was required. The objectives of this study were to investigate the following questions:

1. Can $D$. ambigua be cultured long-term in the laboratory under conditions which do not vary greatly from those already established by the USEPA, and are the life-cycle characteristics of this organism conducive to established toxicity testing methodology?

Feral $D$. ambigua were obtained from local ponds to establish a laboratory population suitable for use in toxicity testing, and at the same time, a laboratory culture of $C$. dubia was initiated. It is essential that good quality test organisms be readily available throughout the year from in-house or commercial sources to meet NPDES requirements (USEPA, 1993). Although it had been shown that $D$. ambigua had been maintained in the laboratory for long periods of time (Hanazato, 1990), it was unknown if this organism could be cultured under the conditions necessary for standard NPDES toxicity testing.

2. How sensitive to toxicants is D. ambigua compared to $C$. dubia?

A comparison of the sensitivity of the two species when exposed to a variety of toxicants was conducted. C. dubia was selected as a standard EPA-recommended test organism because of its sensitivity to a wide range of chemical toxicants. Therefore, when replacing the standard test organism as an indicator species, it is important that the proposed test organism be at least equally sensitive to the same toxicants.

3. Will D. ambigua perform better, in terms of mortality and reproduction, in SRS surface waters than C. dubia?

Performance of the two species when exposed to surface water from three SRS streams was compared. Because the water quality of SRS streams is quite different from that of the culture water of $C$. dubia, the current test organism, a toxic response has been noted when these organisms are exposed to unaltered SRS stream water (Specht, 1994). This portion of the investigation was important in demonstrating whether or not this trend was evident in tests with the indigenous species. 


\section{METHODS}

\section{Culture Conditions}

It was first necessary to determine if $D$. ambigua could be cultured in the laboratory and to determine if methods used for the culture of $C$. dubia were adequate for the successful culture of the proposed test organism. The USEPA protocol for $C$. dubia culture was altered in terms of environmental conditions and feeding requirements until a healthy reproducing population of D. ambigua was established in the laboratory. The final culturing protocol followed a combination of methods outlined by ASTM (1993a), USEPA (1994), and LaPoint et al. (1995) and is described below.

\section{D. ambigua and $C$ dubia Cultures}

A starting population of feral $D$. ambigua were collected from a local pond, sorted from other zooplankton species, and several individuals were selected and isolated. Once these individuals produced two to three broods for the establishment of a culture, they were permanently mounted on microscope slides and taxonomically verified.

Laboratory cultures of $D$. ambigua were maintained in 1.5 liter culture dishes in moderately hard reconstituted water (a solution of reagent-grade chemicals diluted with ultrapure water from a Nanopure ${ }^{\circledR}$ water system) prepared in the laboratory according to specifications by the U.S. EPA (USEPA, 1994). Additional "backup" cultures were maintained in water collected from Fire Pond on SRS. Culture dishes were kept in an environmental chamber with constant temperature $\left(21^{\circ} \mathrm{C} \pm 2\right)$ and a photoperiod of 16 hours light and 8 hours dark. Each culture dish contained 20 to 30 individual daphnids of the same age. Water in culture dishes was renewed at least three times per week, and records were maintained for each dish. The individuals in these dishes produced the neonate daphnids used in toxicity tests. A starter culture of $C$. dubia was obtained from a laboratory supplier (Environmental Consulting and Testing, Superior, WI) and maintained in culture dishes as described above, with the exception of temperature $\left(25^{\circ} \mathrm{C} \pm 2\right.$ for $C$. dubia cultures).

Once the final culture protocol was established, $D$. ambigua were also maintained in "individual cultures" for a period of 7 weeks. In these cultures, sixteen to twenty neonates of the same age were isolated into separate glass vials with 20 milliliters of culture water. These individuals were maintained until they produced at least three broods of young. This exercise provided baseline data on $D$. ambigua survival, reproduction, and culture variability when reared under laboratory conditions.

\section{Feeding}

Both species of daphnids were fed a diet consisting of algae (Selenastrum capricomutum) and a mixture of yeast, alfalfa, and fermented Trout Chow as recommended by the U.S. EPA (USEPA, 1994). Four milliliters of an algal solution (cell density $7.0 \times 10^{7}$ cells $/ \mathrm{mL}$ ) were added to each culture dish when the culture water was renewed (three times per week). An equal amount of the yeast/alfalfa/trout food mixture was added at the same time. Two 
milliliters of each food type were added per day between renewals. For individual cultures, 100 $\mu \mathrm{L} /$ day of each food type was added to each vial.

\section{Food Preparation}

S. capricomutum was grown in the laboratory using Wood's Hole MBL algal media (Stein, 1973) prepared with ultrapure water. Media was mixed and filter sterilized into autoclaved 1-gallon clear Nalgene bottles prior to being inoculated with 1 to 2 milliliters of an axenic starter culture of $S$. capricornutum obtained from a laboratory supplier (Carolina Biological Supply, Burlington, NC). Algal cultures were maintained under continuous light at ambient laboratory temperature; bubbling from a filtered air supply provided continuous mixing. Algal cells were harvested (centrifuged and separated from the media) after two to three weeks when the cell density had reached approximately $8 \times 10^{6}$ cells $/ \mathrm{mL}$. Cell densities were determined by a hemocytometer (Stein, 1973). Once centrifuged, the algal cells formed a pellet which was resuspended in a small volume of ultrapure water. Cell density was then determined in this concentrated solution, and it was diluted to reach a final cell density of $7.0 \times 10^{7}$ cells $/ \mathrm{mL}$ for the final "feeding" solution. The feeding solution was stored under refrigeration for up to one month.

The additional food mixture consisted of a combination of fermented trout food, powdered alfalfa, and yeast. The fermented trout food solution was prepared by adding 5 grams of trout food per liter of ultrapure water. This solution was vigorously aerated at ambient laboratory temperature for 7 days, and water lost to evaporation was replaced. After the digestion period, the solution was allowed to settle for at least 12 hours before the supernatant was separated from the solids. Powdered alfalfa was added to ultrapure water at a rate of 5 grams per liter, then stirred for a minimum of 12 hours using a magnetic stir plate. Solid material was allowed to settle for at least one hour, and the supernatant was combined with an equal volume of the trout food solution and frozen until needed. The yeast solution was prepared by mixing 5 grams of dry baker's yeast (Fleischmann's ${ }^{\circledR}$ ) per liter of ultrapure water. This solution was mixed vigorously by hand then added to the thawed alfalfa and trout food mixtures with no settling period and with no freezing.

\section{TOXICITY TESTING}

Toxicity testing was carried out in two distinct phases. The purpose of the initial phase was to compare both the acute and chronic sensitivity of the two species when exposed to several toxicants in side-by-side testing scenarios. The purpose of the second phase of testing was to gauge the performance of each species in SRS stream water, with and without the addition of a toxicant.

\section{Phase I - Sensitivity Comparison}

The initial phase of testing included: 1.) 48-hour static acute toxicity tests using sodium chloride, copper sulfate, an insecticide (chlorpyrifos), and a surfactant (sodium lauryl sulfate); and 2.) three-brood chronic toxicity tests with sodium chloride and copper sulfate. 
Test Compounds and Analytical Methods

Reagent-grade copper sulfate and sodium chloride were used in both acute and chronic toxicity testing. Copper and sodium in test solutions were measured using a Trace Scan ICP (Thermo Jarrell Ash, Model A-15). For the copper sulfate tests, results were statistically analyzed and reported in terms of the concentration of total copper. Measured sodium concentrations were used to calculate the actual concentration of sodium chloride in test solutions; results were analyzed and reported in terms of sodium chloride concentration. Sodium lauryl sulfate (reagent grade), used in acute tests, was analyzed as a methylene blue active substance following USEPA method 425.1 (USEPA, 1983).

Research-grade chlorpyrifos (Dursban XP, DowElanco, Indianapolis, IN) was used in acute testing. Actual concentrations in test solutions were measured using a Perkin Elmer Q-Mass 910 benchtop GC/MS. Samples were prepared for analysis through a solid-phase microextraction technique (Webster et al., 1996) which used a polymer-coated fused silica fiber to extract the organic compound from the analyte. The fiber, coated with polydimethylsiloxane and attached to a syringe-like apparatus, was exposed to the sample for approximately 15 minutes until a portion of the organic compounds in the sample migrated to the fiber and were sorbed by the polymer coating. Once equilibrium was reached, the fiber was inserted into the injection port of the GC where the analyte was thermally desorbed and the GC/MS procedure was completed as normal.

\section{Acute Testing}

The 48-hour acute static tests were performed following test conditions described in ASTM (1993b). Neonates of each species were exposed to a control treatment and an ascending series of five or six treatment concentrations prepared by spiking dilution water with a concentrated solution of the toxicant. Range-finding tests were conducted initially to aid in the selection of the final test concentrations. Five replicates, each containing ten neonates, were prepared for each concentration; replicates consisted of $250-\mathrm{mL}$ containers with $100 \mathrm{~mL}$ of test solution. Moderately hard reconstituted water (USEPA, 1994) served as the control solution and dilution water for these tests. Test vessels were randomly placed in environmental chambers which controlled photoperiod (16 hours light and 8 hours dark) and maintained a temperature of $25 \pm$ $2^{\circ} \mathrm{C}$ for C. dubia and $21 \pm 2^{\circ} \mathrm{C}$ for $D$. ambigua.

A concentrated solution of chlorpyrifos was prepared by dissolving the compound in analyticalgrade methanol at a rate of $40 \mathrm{mg} / \mathrm{L}$. A concentrated working stock solution was then prepared by spiking dilution water with an aliquot of the methanol/chlorpyrifos mixture. The solvent was present in the highest test concentration at a level of $37.5 \mu \mathrm{L} / \mathrm{L}$, a concentration well below the $500 \mu \mathrm{L} / \mathrm{L}$ maximum recommended by ASTM (1993b) and USEPA (1985). A solvent control was prepared at this concentration $(37.5 \mu \mathrm{L} / \mathrm{L})$ and included with the test. All other test compounds were dissolved directly into laboratory water to produce a concentrated spiking solution.

At test initiation, basic water chemistry parameters (dissolved oxygen, temperature, $\mathrm{pH}$, conductivity, alkalinity, and hardness) were measured in the control and in the highest test concentration. For all other test concentrations, dissolved oxygen, $\mathrm{pH}$, conductivity, and 
temperature were measured. Dissolved oxygen, $\mathrm{pH}$, and temperature were also checked in surrogate test vessels at 24 and 48 hours.

Mortality served as the endpoint for these tests, and results were expressed in terms of the 48hour $\mathrm{LC}_{50}$ (the toxicant concentration lethal to $50 \%$ of the test organisms). These $\mathrm{LC}_{50}$ values were calculated using the Trimmed Spearman-Karber Method, and this statistical analysis was conducted using the CT-TOX Multi-method Computer Program (CTDEP, 1989). The LC 50 values and their corresponding $95 \%$ confidence limits served as an indicator of the relative sensitivities of these two species.

Samples of the test solutions were preserved and analyzed, using the methodology described above, to determine actual toxicant concentrations in test solutions. Because of the differences in toxicant behavior (e.g., the volatile nature of chlorpyrifos), some test solutions were analyzed more rigorously than others. The analytical scenarios are summarized in Table 1.

Table 1. Summary of analytical measurements conducted on test solutions during 48-hour acute toxicity testing.

\begin{tabular}{|l|l|}
\hline Toxicant & Sampling Interval During Acute Testing \\
\hline Sodium chloride & Test initiation \\
\hline Copper sulfate & Test initiation; 48 hours \\
\hline Sodium lauryl sulfate & Test initiation \\
\hline Chlorpyrifos & Test initiation; 24 hours $;$ 48 hours \\
\hline
\end{tabular}

Samples were taken from either actual test vessels or from surrogate vessels which contained an equal volume and an equal number of test organisms as the real test vessels. Actual values were calculated based on the geometric mean of all samples for a particular test concentration.

\section{Chronic Testing}

Chronic three-brood toxicity tests were conducted using sodium chloride and copper sulfate for comparison of the two species at chronic toxicity levels. These tests were conducted following guidelines presented in ASTM (1993a) using laboratory-prepared water as a control and diluent. Neonates (less than 24 hours old) of each species were exposed to a control treatment and an ascending series of treatment concentrations prepared by spiking dilution water with a concentrated solution of the toxicant. The selection of test concentrations was based on abbreviated range-finding tests. Twenty replicates, each containing one neonate, was prepared for each concentration; replicates consisted of $30-\mathrm{mL}$ containers with $20 \mathrm{~mL}$ of test solution. Moderately hard reconstituted water (USEPA, 1994) served as the control solution and dilution water for these tests. Test solutions were renewed daily from stock solutions which were mixed on the first day of testing and stored at $4^{\circ} \mathrm{C}$ for the duration of the test. Test organisms were fed at a rate of $200 \mu \mathrm{L}$ feeding solution/replicate/day. Test solutions were renewed daily, and the duration of chronic toxicity tests depended upon the species. Chronic toxicity tests were conducted until at least $60 \%$ of the control organisms had 3 broods of young. Typically, this took 7 days for $C$. dubia and 10 days for $D$. ambigua. Tests were conducted in environmental chambers which controlled photoperiod (16 hours light and 8 hours dark) and maintained a temperature of $25 \pm 2^{\circ} \mathrm{C}$ for C. dubia and $21 \pm 2^{\circ} \mathrm{C}$ for $D$. ambigua. 
Basic water quality parameters were measured daily in both the renewal solutions and in 24hour old solutions which were stored in the environmental chamber in surrogate test vessels. In the renewal solutions, dissolved oxygen, temperature, $\mathrm{pH}$, conductivity, alkalinity, and hardness were measured in the control and in the highest test concentration. For all other test concentrations, dissolved oxygen, conductivity, $\mathrm{pH}$, and temperature were measured. Dissolved oxygen, $\mathrm{pH}$, and temperature were measured in the surrogate test vessels after 24 hours.

In order to determine the actual toxicant concentration in each test, samples of each stock solution were preserved for analysis at test initiation, the midpoint, and at the end of the test. Copper and sodium were analyzed by Trace Scan ICP as described earlier.

Mortality and reproduction served as test endpoints, and statistical analyses followed guidelines established by the USEPA (1994). Mortality in each test concentration was statistically compared to mortality in the control group by Fisher's Exact Test. If the mortality of a particular group was considered significantly different from the control, the group was dropped from further comparisons; those remaining groups were then analyzed for significant reproductive effects when compared to the control group. The reproductive response used in this analysis was the total number of young produced until either the adult's death or the end of the experiment, whichever came first. The data for each test was determined to be either parametric or nonparametric using the Chi-square test for normality and Bartlett's Test for homogeneity of variance. Test data which passed both of these tests was considered parametric, and the final statistical comparison was conducted by ANOVA and a Dunnett's t-Test. Nonparametric data was analyzed by Steel's Many-One Rank Test. These statistical tests are explained in Zar (1984) and were carried out through the TOXSTAT (Version 3.4) statistical software package (Gulley, 1994).

Phase II - Comparison in SRS Waters

Since the main purpose of this study was to evaluate the appropriateness of an indigenous test organism, it was valuable to evaluate the effects of SRS surface water on each of the two test species, both with and without the influence of a toxicant. Therefore, surface water was collected from three streams on SRS (Upper Three Runs, Pen Branch, and Fourmile Branch) at locations upstream from any outfall and used for testing.

\section{Stream Water Reproductive Success Comparison}

Initially, neonates of each species were exposed to water from each stream in a scenario similar to the one described above for chronic toxicity testing. Twenty replicates, each containing one neonate, was prepared for each water type; replicates consisted of 30-mL containers with $20 \mathrm{~mL}$ of test solution. Moderately hard reconstituted water (USEPA, 1994) served as the control solution and, since this was also the culture water, a basis of comparison for reproductive success if this had been an actual NPDES test. Solutions were renewed daily, and test organisms were fed at a rate of $200 \mu \mathrm{L}$ feeding solution/replicate/day. These tests were continued until at least $60 \%$ of the control organisms had 3 broods of young.

Mortality and reproduction served as endpoints for these tests. The statistical hypothesis testing described in the preceding section and the Kruskal-Wallis Multiple Comparison Test (Zar, 1984) 
were used to compare survival and reproduction of the control organisms (those in the laboratory culture water) to that of the test groups (those in the stream waters).

\section{Acute Stream Water Comparison}

A series of three 48-hour static acute tests was performed in which sodium chloride was added to water from each of the streams, and both species were tested side-by-side. Since the purpose of this set of tests was to compare the responses of the two test organisms in SRS stream water that contained a toxicant (not to repeat the measure of sensitivity), these tests were somewhat less rigorous than the acute tests described above. Only two replicates, of ten organisms each, were exposed to each test concentration, and only the concentrated spiking solutions were analyzed for actual toxicant concentrations. All other methods were the same as those explained in the preceding section. As with the other acute tests, mortality served as the endpoint for these tests, and 48-hour $\mathrm{LC}_{50}$ values were calculated using the Trimmed Spearman-Karber Method (CTDEP, 1989). 


\section{RESULTS AND DISCUSSION}

Prior to any toxicity comparisons, there were two general factors related to this proposed test organism which had to be resolved. First, it was important to ascertain if this species could be cultured on a long-term basis following criteria similar to that already established for C. dubia and, therefore, generally accepted by regulatory agencies. Secondly, it had to be decided if the life cycle characteristics of the proposed test organism were appropriate for traditional acute and chronic toxicity testing.

After some trial and error, it was determined that $D$. ambigua could be cultured using established $C$. dubia protocol (USEPA, 1993; 1994) with only minimal changes. A culture temperature of $21^{\circ} \mathrm{C}$ produced a healthier population than those cultured at the $25^{\circ} \mathrm{C}$ recommended for $C$. dubia. In addition, cell density in the algal feeding solution was increased to $7.0 \times 10^{7}$ cells $/ \mathrm{mL}$ from the $3.0-3.5 \times 10^{7}$ cells $/ \mathrm{mL}$ established by the U.S. EPA. This new feeding solution was used successfully for both species.

D. ambigua demonstrated the ability to be cultured for a long period of time, a characteristic particularly important when using organisms which are not commonly carried by commercial laboratory suppliers and are unavailable from natural populations during certain times of the year. A reproducing population of this species was maintained from generation-to-generation over the entire 16-month period of this investigation.

This initial culturing exercise also provided an indication of the appropriateness of this species as a test organism in terms of life cycle and reproductive success under laboratory conditions. D. ambigua mass cultures regularly produced adequate numbers of neonates for use in toxicity tests. When cultured individually, it was determined that $D$. ambigua would produce 3 broods of young within ten to eleven days, and therefore, could be used in standard 3-brood toxicity tests with a three to four day extension of the test period established in accepted regulatory protocol (USEPA, 1994). Individual cultures also showed a higher overall variance in D. ambigua reproductive data (compared to $C$. dubia) indicating that a higher number of replicates (20 as opposed to the recommended 10) would be a conservative choice for chronic testing.

Another overall disadvantage of the proposed test species was the organism's tendency to float in test solutions. This required careful handling during test solution renewal and was somewhat more time consuming than working with $C$. dubia. Furthermore, this led to the use of glass test vessels as opposed to disposable plastic which enhanced the tendency of floating organisms to stick to the sides.

\section{Phase I - Sensitivity Comparison}

Effluents generally contain a wide variety of toxicants, and test compounds were selected to reflect this variety. Toxicants chosen for this investigation included a metal (copper), an inorganic salt (sodium chloride), a surfactant (sodium lauryl sulfate), and an organic pesticide (chlorpyrifos). While this study did not account for possible synergistic or antagonistic effects of these toxicants, it did provide a simple model for the expected effects of common toxicant classes upon each test species in actual NPDES testing. 
Results of the 48-hour acute toxicity tests are summarized in Table 2 (see Appendix 1 for details). In the side-by-side tests with sodium chloride, copper sulfate, and sodium lauryl sulfate, D. ambigua were less sensitive (i.e., had a higher $\mathrm{LC}_{50}$ ) than $C$. dubia. The opposite, however, was true for the insecticide, chlorpyrifos, where the $\mathrm{LC}_{50}$ for $C$. dubia was somewhat higher than that for $D$. ambigua $(0.056 \mu \mathrm{g} / \mathrm{L}$ and $0.035 \mu \mathrm{g} / \mathrm{L}$, respectively). For each of the toxicants, the 95\% confidence intervals for the two species did not overlap, suggesting a reliable difference in toxicant sensitivity at the time of testing.

Table 2. Forty-eight hour $\mathrm{LC}_{50}$ values for $D$. ambigua and $C$. dubia exposed to sodium chloride, sodium lauryl sulfate, copper, and chlorpyrifos. Values in parenthesis are $95 \%$ confidence limits.

\begin{tabular}{|c|c|c|}
\hline \multirow[t]{2}{*}{ Toxicant } & \multicolumn{2}{|c|}{ 48-hour $\mathrm{LC}_{50}$} \\
\hline & C. dubia & D. ambigua \\
\hline Sodium chloride (mg/L) & $\begin{array}{c}1.59 \\
(1.52-1.67)\end{array}$ & $\begin{array}{c}2.00 \\
(1.81-2.20)\end{array}$ \\
\hline Copper $(\mu \mathrm{g} / \mathrm{L})$ & $\begin{array}{c}4.16 \\
(3.70-4.69)\end{array}$ & $\begin{array}{c}6.53 \\
(6.17-6.92)\end{array}$ \\
\hline Sodium lauryl sulfate $(\mathrm{mg} / \mathrm{L})$ & $\begin{array}{c}1.26 \\
(1.14-1.39)\end{array}$ & $\begin{array}{c}2.44 \\
(2.23-2.67)\end{array}$ \\
\hline Chlorpyrifos $(\mu \mathrm{g} / \mathrm{L})$ & $\begin{array}{c}0.056 \\
(0.054-0.059)\end{array}$ & $\begin{array}{c}0.035 \\
(0.032-0.037)\end{array}$ \\
\hline
\end{tabular}

The chronic 3-brood toxicity test with sodium chloride demonstrated that both species were relatively equal in chronic sensitivity to these toxicants. The No Observed Effect Concentration (NOEC) and Lowest Observed Effect Concentration (LOEC) for C. dubia in sodium chloride were 0.44 and $0.85 \mathrm{~g} / \mathrm{L}$, respectively (Table 3). The $C$. dubia NOEC/LOEC were based upon a combination of both the mortality and reproduction endpoints. NOEC/LOEC values for $D$. ambigua were identical to those of $C$. dubia; however, they were based solely on the mortality endpoint (Tables 4 and 5). In other words, those test concentrations without significant mortality did not show any significant reproductive effects, but mortality was significant at lower concentrations than for $C$. dubia.

Chronic toxicity testing with copper also demonstrated that the chronic sensitivity of the two species was about the same (Tables 3, 6, and 7). Both species had NOEC/LOEC values of 19 and $27 \mu \mathrm{g} / \mathrm{L}$, respectively, and unlike the sodium chloride test, these values were based on a combination of mortality and reproduction for both $C$. dubia and $D$. ambigua. See Appendix 2 for a more detailed presentation of chronic toxicity test data.

Table 3. Summary of the 3-brood chronic toxicity tests with $C$. dubia and $D$. ambigua when exposed to sodium chloride and copper sulfate.

\begin{tabular}{|l|l|l|l|l|}
\hline \multirow{2}{*}{ Toxicant } & \multicolumn{2}{c|}{ C. dubia } & \multicolumn{2}{c|}{ D. ambigua } \\
\cline { 2 - 5 } & \multicolumn{1}{|c|}{ NOEC } & \multicolumn{1}{c|}{ LOEC } & \multicolumn{1}{c|}{ NOEC } & \multicolumn{1}{c|}{ LOEC } \\
\hline Sodium chloride & $0.44 \mathrm{~g} / \mathrm{L}$ & $0.85 \mathrm{~g} / \mathrm{L}$ & $0.44 \mathrm{~g} / \mathrm{L}$ & $0.85 \mathrm{~g} / \mathrm{L}$ \\
\hline Copper & $19 \mu \mathrm{g} / \mathrm{L}$ & $27 \mu \mathrm{g} / \mathrm{L}$ & $19 \mu \mathrm{g} / \mathrm{L}$ & $27 \mu \mathrm{g} / \mathrm{L}$ \\
\hline
\end{tabular}


Table 4. Results of chronic 3-brood toxicity with Ceriodaphnia dubia in sodium chloride. Shaded rows represent the NOEC/LOEC concentrations.

\begin{tabular}{|c|c|c|c|c|c|c|c|c|c|c|c|}
\hline \multirow[t]{2}{*}{$\begin{array}{c}\text { Test Concentration } \\
\text { (g NaCl/L) }\end{array}$} & \multicolumn{8}{|c|}{ Daily Survival (\%) } & \multicolumn{3}{|c|}{$\begin{array}{c}\text { Number of offspring } \\
\text { per female }\end{array}$} \\
\hline & 1 & 2 & 3 & 4 & 5 & 6 & 7 & Sig & $\mathbf{N}$ & Mean & Sig. \\
\hline Control & 100 & 100 & 100 & 100 & 100 & 100 & 100 & - & 20 & 23.6 & - \\
\hline 0.21 & 100 & 100 & 100 & 100 & 100 & 100 & 100 & - & 20 & 22.0 & - \\
\hline 6 & 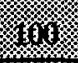 & When & 130 & 8 & 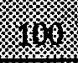 & 30 & 10 & 纹 & 櫂 & 2 & $x$ \\
\hline 6 & 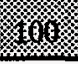 & 40 & 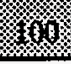 & 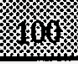 & 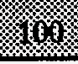 & ror & (100) & 柆. & 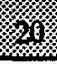 & 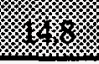 & x. \\
\hline 1.3 & 100 & 100 & 100 & 100 & 100 & 95 & 95 & - & 20 & 12.3 & Yes $^{a}$ \\
\hline 1.7 & 100 & 100 & 95 & 90 & 90 & 85 & 85 & - & 20 & 0.5 & Yes $^{\mathrm{a}}$ \\
\hline 2.2 & 100 & 10 & 10 & $\mathbf{0}$ & $\mathbf{0}$ & $\mathbf{0}$ & $\mathbf{0}$ & Yes $^{b}$ & 20 & $\mathbf{0}$ & $\mathbf{b}$ \\
\hline
\end{tabular}

${ }^{9}$ Reproduction significantly reduced $(\alpha=0.05)$ when compared to the control group using Steel's Many-One Rank Test.

'Survival significantly reduced $(\alpha=0.05)$ when compared to the control group using Fisher's Exact Test. These groups are not considered during the statistical comparison of reproduction.

Table 5. Results of chronic 3-brood toxicity test with Daphnia ambigua in sodium chloride. Shaded rows represent the NOEC/LOEC concentrations.

\begin{tabular}{|c|c|c|c|c|c|c|c|c|c|c|c|c|c|c|}
\hline \multirow{2}{*}{$\begin{array}{c}\text { Test } \\
\text { Concentration } \\
\text { (g NaCl/L) }\end{array}$} & \multicolumn{11}{|c|}{ Daily Survival (\%) } & \multicolumn{3}{|c|}{$\begin{array}{c}\text { Number of offspring } \\
\text { per female }\end{array}$} \\
\hline & 1 & 2 & 3 & 4 & 5 & 6 & 7 & 8 & 9 & 10 & Sig. & $\mathbf{N}$ & Mean & Sig. \\
\hline Control & 100 & 100 & 100 & 100 & 100 & 100 & 100 & 90 & 90 & 90 & - & 20 & 15.1 & - \\
\hline 0.21 & 100 & 100 & 100 & 100 & 100 & 100 & 100 & 95 & 90 & 85 & - & 20 & 15.1 & - \\
\hline 6 & 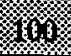 & 80 & x/x & 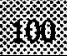 & 纱 & (10\% & $\tan$ & 桑㙏 & 62 & (6) & צ. & 20 & 靖: & x. \\
\hline 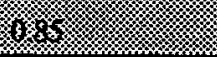 & 60 & 200 & 10 & 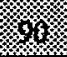 & 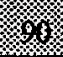 & Kx & 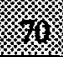 & 66 & 63. & s9 & x. & 20 & $\sqrt{6}$ & . \\
\hline 1.3 & 100 & 100 & 75 & 60 & 30 & 30 & 30 & 30 & 30 & 30 & Yes $^{\mathrm{a}}$ & 20 & 0.25 & a \\
\hline 1.7 & 100 & 100 & 100 & $\mathbf{0}$ & $\mathbf{0}$ & $\mathbf{0}$ & 0 & 0 & 0 & 0 & Yes $^{\mathrm{a}}$ & 20 & 0 & a \\
\hline 2.2 & 100 & 75 & 10 & 10 & 10 & 10 & 10 & 10 & 10 & 10 & Yes $^{\mathrm{a}}$ & 20 & 0 & a \\
\hline
\end{tabular}

a Survival significantly reduced $(\alpha=0.05)$ when compared to the control group using Fisher's Exact Test. These groups are not considered during the statistical comparison of reproduction. 
Table 6. Results of chronic 3-brood toxicity with Ceriodaphnia dubia in copper sulfate. Shaded rows represent the NOEC/LOEC concentrations.

\begin{tabular}{|c|c|c|c|c|c|c|c|c|c|c|c|}
\hline \multirow[t]{2}{*}{$\begin{array}{c}\text { Test Concentration } \\
(\mu \mathrm{g} \mathrm{Cu} / \mathrm{L})\end{array}$} & \multicolumn{8}{|c|}{ Daily Survival (\%) } & \multicolumn{3}{|c|}{$\begin{array}{c}\text { Number of offspring } \\
\text { per female }\end{array}$} \\
\hline & 1 & 2 & 3 & 4 & 5 & 6 & 7 & Sig & $\mathbf{N}$ & Mean & Sig. \\
\hline Control & 100 & 100 & 100 & 100 & 100 & 100 & 100 & - & 20 & 28.4 & - \\
\hline 终的 & 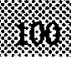 & 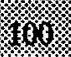 & 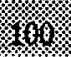 & 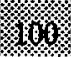 & 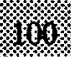 & 維60 & 2 & : & 20 & $26 \%:$ & $x$ \\
\hline 站 & (10) & (x) & 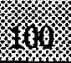 & 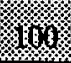 & 100 & \% & 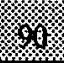 & s. & 83 & $x$ & x. \\
\hline 33 & 100 & 100 & 100 & 100 & 100 & 60 & 60 & Yes $^{b}$ & 20 & 17.0 & b \\
\hline 39 & 100 & 100 & 100 & 100 & 100 & 50 & 50 & Yes $^{b}$ & 20 & 11.8 & b \\
\hline 49 & 100 & 100 & 100 & 95 & 95 & 65 & 65 & Yes $^{b}$ & 20 & 0.4 & b \\
\hline 53 & 100 & 100 & 100 & 100 & 100 & 100 & 100 & - & 20 & 2.4 & Yes $^{a}$ \\
\hline
\end{tabular}

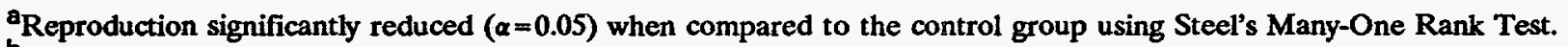
burvival significantly reduced $(\alpha=0.05)$ when compared to the control group using Fisher's Exact Test. These groups are not considered during the statistical comparison of reproduction.

Table 7. Results of chronic 3-brood toxicity test with Daphnia ambigua in copper sulfate. Shaded rows represent the NOEC/LOEC concentrations.

\begin{tabular}{|c|c|c|c|c|c|c|c|c|c|c|c|c|c|c|}
\hline \multirow{2}{*}{$\begin{array}{c}\text { Test } \\
\text { Concentration } \\
(\mu \mathrm{g} \mathrm{Cu} / \mathrm{L})\end{array}$} & \multicolumn{11}{|c|}{ Daily Survival (\%) } & \multicolumn{3}{|c|}{$\begin{array}{c}\text { Number of offspring } \\
\text { per female }\end{array}$} \\
\hline & 1 & 2 & 3 & 4 & 5 & 6 & 7 & 8 & 9 & 10 & Sig. & $\mathbf{N}$ & Mean & Sig. \\
\hline Control & 100 & 100 & 100 & 100 & 100 & 100 & 100 & 100 & 100 & 95 & - & 20 & 19.7 & - \\
\hline 㱍 & 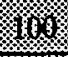 & 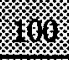 & 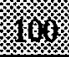 & (n) & 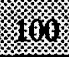 & \% & 叕 & 6 & (1) & 10 & x & \% & 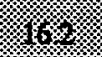 & $x$ \\
\hline x & xix & 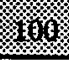 & 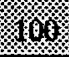 & (6) & 6 & 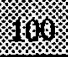 & (x) & 叕6 & s. & $x$ & 誃 & s. & 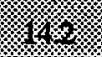 & K \\
\hline 33 & 100 & 100 & 100 & 100 & 100 & 100 & 100 & 100 & 100 & 100 & - & 20 & 7.5 & $\operatorname{Yes}^{a}$ \\
\hline 39 & 100 & 100 & 100 & 100 & 100 & 65 & 65 & 65 & 65 & 65 & Yes $^{b}$ & 20 & 3.5 & $\mathbf{b}$ \\
\hline 49 & 100 & 100 & 100 & 90 & 90 & 55 & 55 & 55 & 55 & 55 & Yes $^{b}$ & 20 & 2.6 & b \\
\hline 53 & 100 & 100 & 100 & 100 & 90 & 55 & 45 & 45 & 45 & 45 & Yes $^{b}$ & 20 & 0.2 & b \\
\hline
\end{tabular}

a Reproduction significantly reduced $(\alpha=0.05)$ when compared to the control group using ANOVA and Dunnett's t-Test. burvival significantly reduced $(\alpha=0.05)$ when compared to the control group using Fisher's Exact Test. These groups are not considered during the statistical comparison of reproduction. 
Various NPDES permits for SRS require the use of receiving stream water as a diluent during routine toxicity testing; therefore, it was considered beneficial to demonstrate the reproductive success and sensitivity to toxicants of each species when exposed to stream water from several sources on SRS. Also, the use of actual onsite surface water presented a more realistic model of site-specific conditions and subsequent organism response. The results of Phase II are presented in this section, and a more detailed presentation of the test data is given in Appendix 3.

When exposed to the three SRS stream waters (Pen Branch, Four Mile Branch, and Upper Three Runs) in the chronic 3-brood study, C. dubia showed a significant reduction in reproduction in two of the three streams tested, when compared to reproductive rates in the laboratory control (Table 8). In contrast, $D$. ambigua reproductive rates increased in the stream waters when compared to the laboratory control group. Mortality was not a significant factor for either species during this study.

This exercise demonstrated the reproductive success which could be expected from each species in SRS surface water and showed whether or not significant differences existed merely from exposure to the surface water without the addition of a toxicant. The response of $C$. dubia to the stream water could be attributed to the differences in site-specific water quality versus that of the traditional laboratory culture water (Table 9). Surface water in southeastern streams such as Four Mile Branch and Upper Three Runs are characterized by low hardness and pH, possibly accounting for the "toxic" response of $C$. dubia when exposed to this water. Water from Pen Branch, which has a somewhat higher $\mathrm{pH}$ and hardness, had no apparent negative effect on $C$. dubia during this 7-day period. Since moderately hard reconstituted water is the culture water recommended for $C$. dubia by the USEPA (1994), it is used in most commercial laboratories. The $C$. dubia reproductive effects demonstrated by this test are indicative of what may happen in actual NPDES tests which require the use of SRS surface water as a control and diluent. Stated simply, chronic effects noted in effluent tests from this site may be due to the dilution water itself, not because of any particular toxicant.

Table 8. Results of the 3-brood stream water reproductive success study performed with laboratory water and surface water from three streams on SRS.

\begin{tabular}{|l|l|l|l|l|}
\hline \multirow{2}{*}{ Water Type } & \multicolumn{2}{c|}{ Percent Survival } & \multicolumn{2}{c|}{$\begin{array}{c}\text { Mean Number of Young per } \\
\text { Female }(\mathrm{N}=20)\end{array}$} \\
\cline { 2 - 5 } & \multicolumn{1}{c|}{ C. dubia } & D. ambigua & \multicolumn{1}{c|}{ C. dubia } & D. ambigua \\
\hline Control (laboratory water) & 100 & 100 & 32.2 & 18.3 \\
\hline Pen Branch & 100 & 100 & 32.4 & 24.8 \\
\hline Four Mile Branch & 100 & 100 & $9.8^{\mathrm{a}}$ & 23.6 \\
\hline Upper Three Runs & 90 & 100 & $24.3^{\mathrm{a}}$ & 24.5 \\
\hline
\end{tabular}

${ }^{d}$ Reproduction significantly reduced $(\alpha=0.05)$ when compared to the control group using Steel's Many-One Rank Test. 
Table 9. Summary of water quality parameters measured on daily renewal solutions for the stream water reproduction study. Values are expressed as means, ranges are presented in parentheses, $N=10$.

\begin{tabular}{|l|c|c|c|c|}
\hline \multirow{2}{*}{ Parameter } & \multicolumn{4}{|c|}{ Water Type } \\
\cline { 2 - 5 } & $\begin{array}{c}\text { Laboratory } \\
\text { Reconstituted Water }\end{array}$ & Pen Branch & Four Mile Branch & Upper Three Runs \\
\hline $\mathrm{pH}$ & $\begin{array}{c}8.22 \\
(8.15-8.30)\end{array}$ & $\begin{array}{c}7.64 \\
(7.56-7.72)\end{array}$ & $\begin{array}{c}5.63 \\
(5.47-5.80)\end{array}$ & $\begin{array}{c}6.53 \\
(6.33-6.76)\end{array}$ \\
\hline $\begin{array}{l}\text { Hardness } \\
\left(\mathrm{mg} / \mathrm{L} \text { as } \mathrm{CaCO}_{3}\right)\end{array}$ & $\begin{array}{c}67.1 \\
(58-72)\end{array}$ & $\begin{array}{c}18.6 \\
(16-22)\end{array}$ & $\begin{array}{c}7.4 \\
(6.0-8.0)\end{array}$ & $\begin{array}{c}7.4 \\
(6.0-10.0)\end{array}$ \\
\hline $\begin{array}{l}\text { Alkalinity } \\
\left(\mathrm{mg} / \mathrm{L} \text { as } \mathrm{CaCO}_{3}\right)\end{array}$ & $\begin{array}{c}59.2 \\
(56-62)\end{array}$ & $\begin{array}{c}25.4 \\
(24.0-26.0)\end{array}$ & $\begin{array}{c}5.5 \\
(4.0-6.0)\end{array}$ & $\begin{array}{c}3.8 \\
(3.0-4.0)\end{array}$ \\
\hline $\begin{array}{l}\text { Conductivity } \\
(\mu \mathrm{s} / \mathrm{cm})\end{array}$ & $\begin{array}{c}245.6 \\
(239-251)\end{array}$ & $\begin{array}{c}54.1 \\
(53.1-54.7)\end{array}$ & $\begin{array}{c}25.5 \\
(24.9-25.7)\end{array}$ & $\begin{array}{c}13.3 \\
(13.1-13.5)\end{array}$ \\
\hline $\begin{array}{l}8 \text { Dissolved Oxygen } \\
\text { (mg/L) }\end{array}$ & $(8.54-8.75)$ & $\begin{array}{c}8.36 \\
(8.24-8.67)\end{array}$ & $\begin{array}{c}8.36 \\
(8.24-8.54)\end{array}$ & $\begin{array}{c}8.26 \\
(8.16-8.42)\end{array}$ \\
\hline
\end{tabular}

Furthermore, results of this study are consistent with a similar study, Specht (1994), which took water from these same three streams and documented water quality and $C$. dubia reproductive success over a period of 11 months. Specht (1994) found that survival and/or reproduction was impaired when $C$. dubia was cultured in water from these three streams over an extended period of time.

D. ambigua, on the other hand, adapted much more easily to the change in water chemistry from the laboratory culture water to the SRS stream water. When the data from the $D$. ambigua test was statistically analyzed (Kruskal-Wallis Multiple Comparison Test; Zar, 1984), reproduction in those groups exposed to stream water was significantly greater than that of the control group.

Table 10 summarizes the results of 48-hour acute tests with sodium chloride in each of the three stream waters. The results of the Four Mile Branch and Upper Three Runs tests mirrored those of the original sodium chloride sensitivity comparison conducted in laboratory water; $D$. ambigua were less sensitive to the toxicant than $C$. dubia. There was a general decrease in $\mathrm{LC}_{50}$ values for both species when compared to laboratory water, but this is to be expected due to the lower hardness of the stream water. In water from Pen Branch (the stream with a somewhat higher hardness and $\mathrm{pH}$ ), the $\mathrm{LC}_{50}$ for $C$. dubia was slightly higher than that for $D$. ambigua (1.54 and 1.40 , respectively), but overlapping confidence limits make this difference negligible. It is difficult to determine whether the difference in sodium chloride $\mathrm{LC}_{50}$ values for the two species, particularly in Upper Three Runs and Four Mile Branch, is due to an effect from the dilution water or just general differences in species sensitivity. 
Table 10. Forty-eight hour toxicity test results for $D$. ambigua and $C$. dubia exposed to sodium chloride using water from three SRS streams as a diluent. $\mathrm{LC}_{50}$ concentrations are expressed in terms of $\mathrm{g} / \mathrm{L}$. Values in parenthesis are $95 \%$ confidence limits.

\begin{tabular}{|l|c|c|}
\hline \multirow{2}{*}{ SRS Stream Water Diluent } & \multicolumn{2}{|c|}{ 48-hour LC $_{50}$} \\
\cline { 2 - 3 } & C. dubia & D. ambigua \\
\hline Upper Three Runs & 0.15 & 0.58 \\
& $(0.13-0.17)$ & $(0.53-0.64)$ \\
\hline Pen Branch & 1.54 & 1.40 \\
& $(1.47-1.61)$ & $(1.31-1.50)$ \\
\hline Four Mile Branch & 0.37 & $0.63^{\mathrm{a}}$ \\
& $(0.33-0.43)$ & $(0.45-0.89)$ \\
\hline Laboratory Water & 1.59 & 2.00 \\
(copied from Table 2 for comparison) & $(1.52-1.67)$ & $(1.81-2.20)$ \\
\hline
\end{tabular}

${ }^{d} \mathrm{LC}_{50}$ and confidence limits calculated by the Binomial Method due to the nature of the data (i.e., no partial mortalities in test concentrations; see Appendix 3). 


\section{SUMMARY}

This investigation determined that $D$. ambigua can be cultured following basically the same accepted guidelines for $C$. dubia, and the life cycle characteristics of the proposed test organism make it an ideal candidate for NPDES testing. Disadvantages of this species include some difficulty in handling and a greater reproductive variance over $C$. dubia; however, these problems are relatively easy to overcome and are not particularly cost prohibitive.

Acute testing showed that $D$. ambigua were less sensitive to sodium chloride, copper, and sodium lauryl sulfate compared to $C$. dubia, but were also more sensitive to the insecticide, chlorpyrifos. Chronic testing with sodium chloride and copper showed toxicant sensitivities which were relatively equal between the two species. This is not surprising since $C$. dubia chronic tests are conducted at a higher temperature, resulting in greater toxicant uptake, while D. ambigua tests are conducted for a longer period of time (10 days versus 7 days). This apparently results in a "balance" of chronic toxicant sensitivity between the two species.

When exposed to unaltered surface water from three SRS streams (Upper Three Runs, Pen Branch, and Four Mile Branch), C. dubia demonstrated negative reproductive effects in water from two of these streams, Upper Three Runs and Four Mile Branch. At the same time, reproduction for $D$. ambigua actually increased significantly in all three streams when compared to the culture water control. When a toxicant (sodium chloride) was tested using these stream waters, there was an overall decrease in $\mathrm{LC}_{50}$ values for both species compared to tests with laboratory water (presumably because of the lower dilution water hardness). As with the general sensitivity tests (those performed in laboratory water), $D$. ambigua was somewhat less sensitive to the toxicant when tested in two of the three streams, but $\mathrm{LC}_{50}$ values were similar in the test with water collected from Pen Branch.

In conclusion, this study indicated that $D$. ambigua would be a reasonable replacement for $C$. dubia for site-specific testing at SRS. While testing with $D$. ambigua may result in a loss of the overall acute sensitivity (compared to C. dubia) to some toxicants, there was also an indication of increased sensitivity to others (e.g., chlorpyrifos). In chronic tests, which are the actual tests used to determine NPDES compliance at SRS, the two species showed equal sensitivity. This potential "trade off" may provide a more realistic model of actual instream effects at SRS. Also, when testing in receiving stream water, the use of $D$. ambigua may eliminate the potential of observed effects caused by vast differences in dilution water characteristics versus those of the culture water. Using this species will avoid this uncertainty and still provide a dependable level of protection for indigenous aquatic fauna. 


\section{REFERENCES}

ASTM (American Society for Testing and Materials). 1993a. Standard Guide for Conducting Three-Brood, Renewal Toxicity Tests with Ceriodaphnia dubia. ASTM Standards on Aquatic Toxicology and Hazard Evaluation. Designation E-1295-89. ASTM. Philadelphia, PA.

ASTM. 1993b. Standard Guide for Conducting Acute Toxicity Tests with Fishes, Macroinvertebrates, and Amphibians. ASTM Standards on Aquatic Toxicology and Hazard Evaluation. Designation E-729-88a. ASTM. Philadelphia, PA.

Clements, W.H. and P.M. Kiffney. 1996. Validation of Whole Effluent Toxicity Tests: Integrated Studies Using Field Assessments, Microcosms, and Mesocosms. In: Grothe, D.R., K.L. Dickson, and D.K. Reed-Judkins, eds. Whole Effluent Toxicity Testing: An Evaluation of Methods and Prediction of Receiving System Impacts. A publication of the Society of Environmental Toxicology and Chemistry. SETAC Press, Pensacola, FL. pp. 229-244

CTDEP (Connecticut Department of Environmental Protection). 1989. CT-TOX Multimethod Computer Program. IBM PC Version 1.0. Statistical Software package developed by the Bureau of Water Management, Connecticut DEP, Water Toxics Laboratory. Hartford, CT.

Federal Register. 1996. Stakeholder's Meeting on Whole Effluent Toxicity (WET) Implementation Issues. US Environmental Protection Agency. August 7, 1996. 61 FR 41149.

Gulley, D. 1994. TOXSTAT. Version 3.4. Statistical software package developed by the University of Wyoming and Western EcoSystems Technology, Inc. Chyenne, WY.

Hanazato, T. 1990. Induction of helmet development by a Chaoborus factor in Daphnia ambigua during juvenile stages. Journal of Plankton Research. 12(6):1287-1294.

LaPoint, T.W., L. Esman, C. Fornstrom, J. Gottschlak, and A. Paul. 1995. Toxicity Testing of Indigenous Species of Zooplankton. Final Draft Report submitted to the South Carolina Universities Research and Education Foundation (SCUREF) by The Institute of Wildlife and Environmental Toxicology (TIWET). Clemson University. Pendelton, SC.

Rand, G.M. and S.R. Petrocelli. 1985. Fundamentals of Aquatic Toxicology: Methods and Applications. Hemisphere Publishing Corporation. Washington, DC. 666 pp.

Specht, W.L. 1994. Reproductive Success and Mortality Rates of Ceriodaphnia dubia Maintained in Water from Upper Three Runs, Pen Branch, and Fourmile Branch. SRC-TR-950005. Westinghouse Savannah River Company. Aiken, SC.

Stein, J. R. 1973. Handbook of Phycological Methods. Cambridge Press. New York, NY.

USEPA (US Environmental Protection Agency). 1983. Methods for Chemical Analysis of Water and Wastes. EPA-600-4-79-020. Environmental Protection Agency. Office of Research and Development. Cincinnati, $\mathrm{OH}$. 
USEPA. 1985. Hazard Evaluation Division Standard Evaluation Procedure: Acute Toxicity Test for Freshwater Invertebrates. EPA-540-9-85-005. U.S. Environmental Protection Agency. Office of Pesticide Programs. Washington, DC.

USEPA. 1993. Methods for Measuring the Acute Toxicity of Effluents and Receiving Waters to Freshwater and Marine Organisms. Fourth Edition. EPA-600-4-90-027F. U.S. Environmental Protection Agency. Office of Research and Development. Cincinnati, $\mathrm{OH}$.

USEPA. 1994. Short-Term Methods for Estimating the Chronic Toxicity of Effluents and Receiving Waters to Freshwater Organisms. Third Edition. EPA-600-4-91-002. U.S. Environmental Protection Agency. Office of Research and Development. Cincinnati, $\mathrm{OH}$.

Webster, G.R.B., Sarna, L.P., and Graham, K.N. 1996. Solid phase microextraction. In: Ostrander, G.K., ed. 1996. Techniques in Aquatic Toxicology. Lewis Publishers. Boca Raton, FL. pp 459-477.

Zar, J.H. 1984. Biostatistical Analysis. Prentice Hall, Inc. Englewood Cliffs, NJ. 718 pp. 


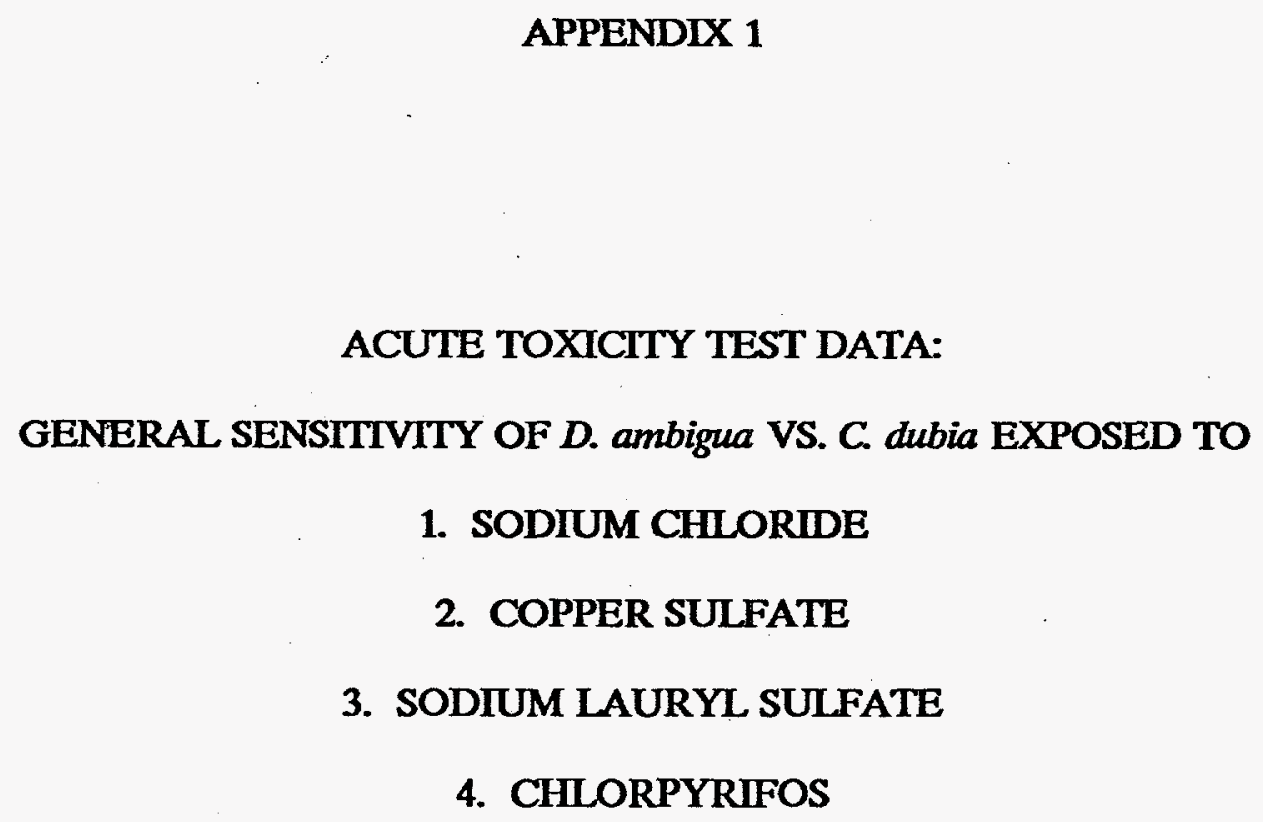


APPENDIX 1 A

ACUTE TOXICITY TEST DATA:

D. ambigua AND C dubia EXPOSED TO SODIUM CHLORIDE 
Nominal and actual concentrations of sodium chloride in solutions used for acute toxicity testing. Actual concentrations of sodium were measured on initial test solutions and are applicable to the testing for both species. Values were determined by Trace Scan ICP.

\begin{tabular}{|c|c|c|c|}
\hline $\begin{array}{c}\text { Nominal NaC } \\
\text { Concentration } \\
(\mathrm{g} / \mathrm{L})\end{array}$ & $\begin{array}{c}\text { Measured Na } \\
\text { Concentration } \\
(\mathrm{g} / \mathrm{L})\end{array}$ & $\begin{array}{c}\text { Measured Na } \\
\text { minus } \\
\text { Background Na } \\
\text { Concentration } \\
(\mathrm{g} / \mathrm{L})\end{array}$ & $\begin{array}{c}\text { Actual NaC } \\
\text { Concentration } \\
(\mathrm{g} / \mathrm{L})\end{array}$ \\
\hline 0.5 & 0.213 & 0.188 & 0.479 \\
\hline 1 & 0.370 & 0.345 & 0.879 \\
\hline 1.5 & 0.526 & 0.501 & 1.27 \\
\hline 2 & 0.728 & 0.703 & 1.79 \\
\hline 2.5 & 0.913 & 0.888 & 2.26 \\
\hline
\end{tabular}

${ }^{1}$ Background Na concentration $=0.0248 \mathrm{~g} / \mathrm{L}$.

${ }^{2}$ Concentration of $\mathrm{NaCl}$ was calculated using the following formula: $[\mathrm{NaCl}]=([\mathrm{Na}] / 22.9) * 58.35$ 


\section{APPENDIX $1 \mathrm{~A}$}

Forty-eight hour mortality observations on $C$. dubia in the sodium chloride toxicity test.

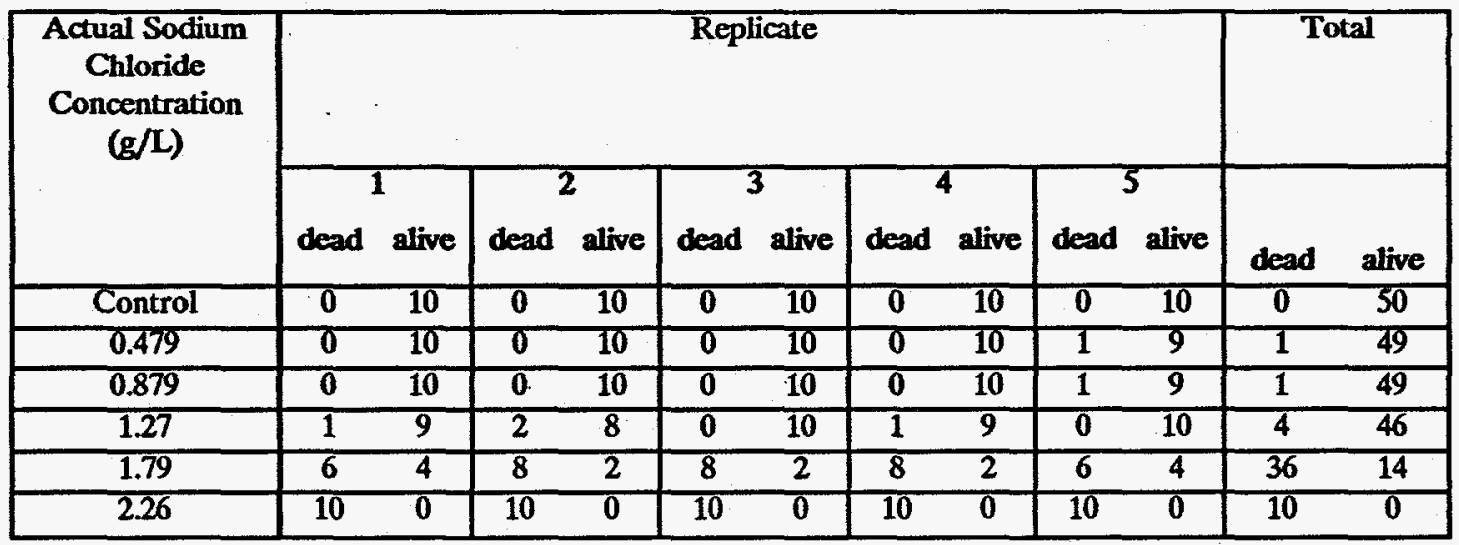

48-hour $\mathrm{LC}_{50}=1.59 \mathrm{~g} / \mathrm{L}(95 \%$ confidence limits $=1.52-1.67 \mathrm{~g} / \mathrm{L})$.

Forty-eight hour mortality observations on $D$. ambigua in the sodium chloride toxicity test.

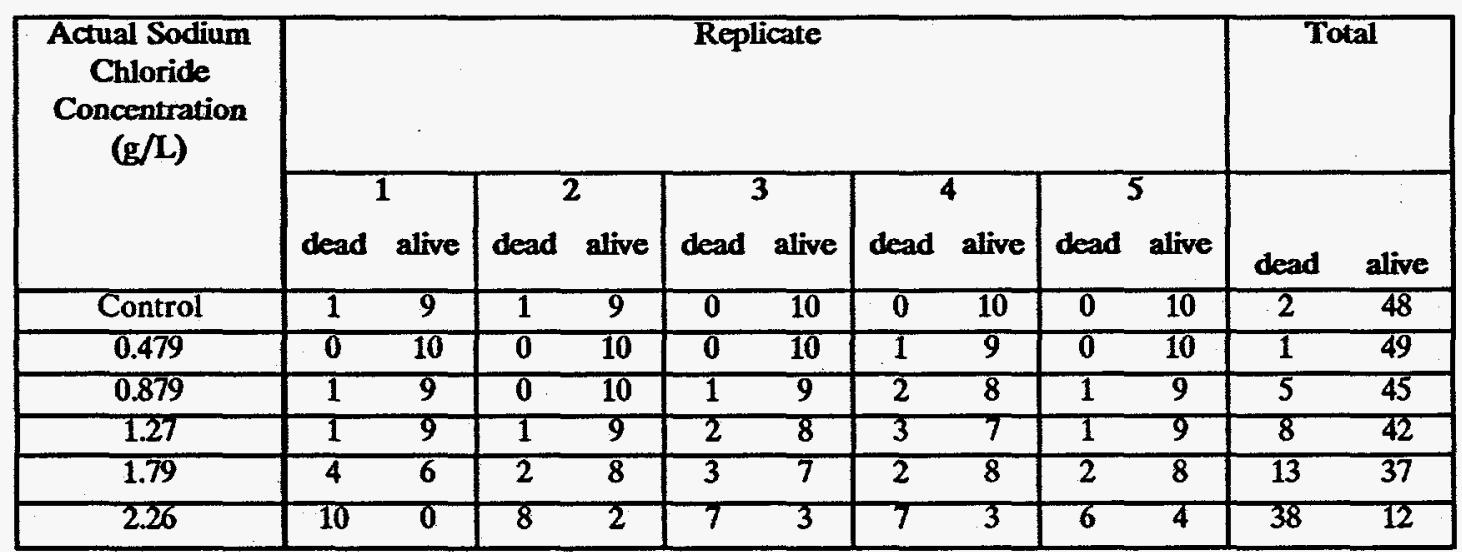

48-hour $\mathrm{LC}_{50}=2.00 \mathrm{~g} / \mathrm{L}(95 \%$ confidence limits $=1.81-2.20 \mathrm{~g} / \mathrm{L})$. 
Summary of statistical analysis for the $C$. dubia 48-hour acute test with sodium chloride.

\section{CT-TOX MULTI-METHOD PROGRAM}

Binomial, Moving average, Probit, and Spearman-Karber Methods

TEST SUMMARY

DATE: 5-29-97

DURATION: 48 hours

SAMPLE: Sodium chloride $(\mathrm{g} / \mathrm{L})$

SPECIES: Ceriodaphnia dubia

\begin{tabular}{|l|c|c|c|c|}
\hline \multirow{2}{*}{ METHOD } & \multirow{2}{*}{ LC50 } & \multicolumn{3}{c|}{ CONFIDENCE LIMITS } \\
\cline { 3 - 5 } & & LOWER & UPPER & SPAN \\
\hline Binomial & 1.606 & 1.270 & 1.790 & 0.520 \\
\hline MAA & 1.477 & 1.377 & 1.596 & 0.219 \\
\hline Probit & 1.541 & $* * * *$ & $* * * *$ & $* * * *$ \\
\hline Spearman-Karber & 1.591 & 1.516 & 1.669 & 0.153 \\
\hline
\end{tabular}

**** = Limit does not exist.

\section{TRIMMED SPEARMAN-KARBER SUMMARY}

Trim:

$2.00 \%$

LC50:

1.591

95\% Lower confidence: $\quad 1.516$

95\% Upper confidence: $\quad 1.669$

\section{BINOMIAL METHOD}

\begin{tabular}{|c|c|c|c|l|}
\hline $\begin{array}{c}\text { Concentration } \\
(\mathrm{g} / \mathrm{L})\end{array}$ & $\begin{array}{c}\text { Number } \\
\text { Exposed }\end{array}$ & $\begin{array}{c}\text { Number } \\
\text { Dead }\end{array}$ & $\begin{array}{c}\text { Percent } \\
\text { Dead }\end{array}$ & $\begin{array}{c}\text { Binomial } \\
\text { Probability (\%) }\end{array}$ \\
\hline 0.48 & 50 & 1 & 2 & $0.450 \mathrm{D}-11$ \\
\hline 0.88 & 50 & 1 & 2 & $0.4530 \mathrm{D}-11$ \\
\hline 1.27 & 50 & 4 & 8 & $0.2231 \mathrm{D}-07$ \\
\hline 1.79 & 50 & 36 & 72 & $0.1301 \mathrm{D}+00$ \\
\hline 2.26 & 50 & 50 & 100 & $0.8882 \mathrm{D}-13$ \\
\hline
\end{tabular}

The binomial test shows that 1.27 and 1.79 can be statistically sound conservative 95 percent confidence limits since the actual confidence level associated with these limits is 99.8699 percent. An approximate LC50 for this data set is $\mathbf{1 . 6 0 6 .}$ 
RESULTS USING MOVING AVERAGE

Span G LC50 95\% Confidence limit

$\begin{array}{lllll}4 & .0173 & 1.48 & 1.38 & 1.60\end{array}$

\section{RESULTS CALCULATED BY PROBIT METHOD}

$\underset{8}{\operatorname{ITERATIONS}} \mathrm{G} \underset{* * * * * *}{\mathrm{H}} \quad$ GOODNESS OF FIT

A probability of 0 means less than 0.001

Slope $=8.66$

95\% Confidence limits: -100.32 And 117.63

$\mathrm{LC} 50=1.54$

95\% Confidence limits: 0 and + infinity

$\mathrm{LC} 1=.83$

95\% Confidence limits: 0 and + infinity 
Summary of statistical analysis for the $D$. ambigua 48 -hour acute test with sodium chloride.

\section{CT-TOX MULTI-METHOD PROGRAM}

Binomial, Moving average, Probit, and Spearman-Karber Methods

\section{TEST SUMMARY}

DATE: 5-29-97

DURATION: 48 hours

SAMPLE: sodium chloride SPECIES: Daphnia ambigua

\begin{tabular}{|l|c|c|c|c|}
\hline \multirow{2}{*}{ METHOD } & \multirow{2}{*}{ LC50 } & \multicolumn{3}{|c|}{ CONFIDENCE LIMITS } \\
\cline { 3 - 5 } & & LOWER & UPPER & SPAN \\
\hline Binomial & 2.001 & 1.790 & 2.260 & 0.470 \\
\hline MAA & 1.991 & 1.842 & 2.213 & 0.370 \\
\hline Probit & 1.938 & $* * * *$ & $* * * *$ & $* * * *$ \\
\hline Spearman-Karber & 2.000 & 1.814 & 2.204 & 0.390 \\
\hline
\end{tabular}

${ }^{* * * *}=$ Limit does not exist.

\section{TRIMMED SPEARMAN-KARBER SUMMARY}

Trim: $24 \%$

LC50:

95\% Lower confidence: $\quad 1.814$

95\% Upper confidence: $\quad 2.204$

\section{BINOMIAL METHOD}

\begin{tabular}{|c|c|c|c|l|}
\hline $\begin{array}{c}\text { Concentration } \\
(\mathrm{g} / \mathrm{L})\end{array}$ & $\begin{array}{c}\text { Number } \\
\text { Exposed }\end{array}$ & $\begin{array}{c}\text { Number } \\
\text { Dead }\end{array}$ & $\begin{array}{c}\text { Percent } \\
\text { Dead }\end{array}$ & $\begin{array}{c}\text { Binomial } \\
\text { Probability (\%) }\end{array}$ \\
\hline 0.48 & 50 & 1 & 2 & $.4530 \mathrm{D}-11$ \\
\hline 0.88 & 50 & 5 & 10 & $.2105 \mathrm{D}-06$ \\
\hline 1.28 & 50 & 8 & 16 & $.5818 \mathrm{D}-04$ \\
\hline 1.79 & 50 & 13 & 26 & $.4681 \mathrm{D}-01$ \\
\hline 2.26 & 50 & 38 & 76 & $.1529 \mathrm{D}-01$ \\
\hline
\end{tabular}

The binomial test shows that 1.79 and 2.26 can be statistically sound conservative 95 percent confidence limits since the actual confidence level associated with these limits is 99.9379 percent. An approximate LC50 for this data set is 2.001 . 
RESULTS USING MOVING AVERAGE

Span G LC50 95\% Confidence limit

$\begin{array}{lllll}2 & .0951 & 1.99 & 1.84 & 2.21\end{array}$

RESULTS CALCULATED BY PROBIT METHOD

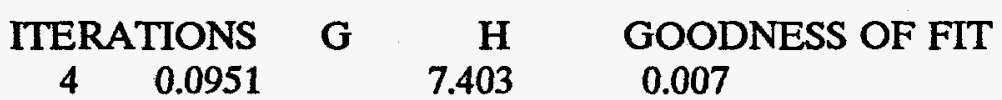

Since the probability is less than 0.05 ,

Results calculated using the probit method probably should not be used.

SLOPE $=6.82$

95\% CONFIDENCE LIMITS: -35.01 AND 48.64

$\mathrm{LC} 50=1.94$

95\% CONFIDËNCE LIMITS: 0 AND + INFINITY

$\mathrm{LC} 1=.88$

95\% CONFIDENCE LIMITS: 0 AND + INFINITY 
TEST: $\quad$ Sodium chloride test with $C$. dubia

Start Date: $\quad 5 / 27 / 97$

Initial Water Chemistry

\begin{tabular}{|c|c|c|c|c|c|c|}
\hline $\begin{array}{c}\text { Concentration } \\
(\mathrm{g} / \mathrm{L}) \\
\end{array}$ & $\begin{array}{c}\mathrm{DO} \\
(\mathrm{mg} / \mathrm{L})\end{array}$ & pH & $\begin{array}{c}\text { Temperature } \\
\left({ }^{\circ} \mathrm{C}\right) \\
\end{array}$ & $\begin{array}{c}\text { Conductivity } \\
(\mathrm{ms} / \mathrm{cm})\end{array}$ & $\begin{array}{c}\text { Alkalinity } \\
\left(\mathrm{mg} / \mathrm{L} \text { as } \mathrm{CaCO}_{3}\right)\end{array}$ & $\begin{array}{c}\text { Hardness } \\
(\mathrm{mg} / \mathrm{L} \text { as } \mathrm{CaCO}) \\
\end{array}$ \\
\hline Control & 7.73 & 8.26 & 24.8 & 0.224 & 62 & 64 \\
\hline 0.479 & 8.55 & 8.25 & 24.0 & 1.140 & & \\
\hline 0.879 & 9.03 & 8.20 & 24.1 & 20.800 & & \\
\hline 1.27 & 7.97 & 8.16 & 24.1 & 2.940 & & \\
\hline 1.79 & 8.31 & 8.15 & 24.1 & 3.860 & & \\
\hline 2.26 & 8.22 & 8.20 & 24.3 & 4.750 & 62 & 66 \\
\hline
\end{tabular}

24-Hour Readings

\begin{tabular}{cccc}
\hline $\begin{array}{c}\text { Concentration } \\
(\mathrm{g} / \mathrm{L})\end{array}$ & $\begin{array}{c}\text { DO } \\
(\mathbf{m g} / \mathrm{L})\end{array}$ & $\mathrm{pH}$ & $\begin{array}{c}\text { Temperature } \\
\left({ }^{\circ} \mathrm{C}\right)\end{array}$ \\
\hline Control & 8.18 & 8.46 & 24.2 \\
0.479 & 8.33 & 8.45 & 24.5 \\
0.879 & 8.06 & 8.41 & 24.9 \\
1.27 & 8.08 & 8.39 & 24.5 \\
1.79 & 8.25 & 8.40 & 24.2 \\
2.26 & 8.15 & 8.39 & 24.8 \\
\hline
\end{tabular}

48-Hour Readings

\begin{tabular}{cccc}
\hline $\begin{array}{c}\text { Concentration } \\
(\mathrm{g} / \mathrm{L})\end{array}$ & $\begin{array}{c}\text { DO } \\
(\mathbf{m g} / \mathbf{L})\end{array}$ & $\mathbf{p H}$ & $\begin{array}{c}\text { Temperature } \\
\left({ }^{\circ} \mathbf{C}\right)\end{array}$ \\
\hline Control & 8.31 & 8.45 & 24.0 \\
0.479 & 8.16 & 8.46 & 24.2 \\
0.879 & 8.28 & 8.42 & 24.3 \\
1.27 & 8.10 & 8.38 & 24.4 \\
1.79 & 7.86 & 8.41 & 24.0 \\
2.26 & 8.21 & 8.44 & 24.1 \\
\hline
\end{tabular}


TEST: $\quad$ Sodium chloride test with $D$. ambigua

Start Date: $\quad$ 5/27/97

Initial Water Chemistry

\begin{tabular}{ccccccc}
\hline $\begin{array}{c}\text { Concentration } \\
(\mathrm{g} / \mathrm{L})\end{array}$ & $\begin{array}{c}\mathrm{DO} \\
(\mathrm{mg} / \mathrm{L})\end{array}$ & $\mathbf{p H}$ & $\begin{array}{c}\text { Temperature } \\
\left({ }^{\circ} \mathrm{C}\right)\end{array}$ & $\begin{array}{c}\text { Conductivity } \\
(\mathrm{ms} / \mathrm{cm})\end{array}$ & $\begin{array}{c}\text { Alkalinity } \\
\left(\mathrm{mg} / \mathrm{L} \text { as } \mathrm{CaCO}_{3}\right)\end{array}$ & $\begin{array}{c}\text { Hardness } \\
\left(\mathrm{mg} / \mathrm{L} \text { as } \mathrm{CaCO}_{3}\right)\end{array}$ \\
\hline Control & 7.97 & 8.24 & 21.1 & 0.240 & 62 & 64 \\
0.479 & 8.23 & 8.25 & 20.8 & 1.153 & & \\
0.879 & 8.34 & 8.19 & 21.1 & 2.080 & & \\
1.27 & 8.01 & 8.20 & 21.3 & 2.950 & & \\
1.79 & 7.86 & 8.21 & 21.4 & 3.650 & & 66 \\
2.26 & 8.11 & 8.20 & 20.9 & 4.480 & 62 & \\
\hline
\end{tabular}

24-Hour Readings

\begin{tabular}{cccc}
\hline $\begin{array}{c}\text { Concentration } \\
(\mathrm{g} / \mathrm{L})\end{array}$ & $\begin{array}{c}\text { DO } \\
(\mathbf{m g} / \mathrm{L})\end{array}$ & $\mathbf{p H}$ & $\begin{array}{c}\text { Temperature } \\
\left({ }^{\circ} \mathrm{C}\right)\end{array}$ \\
\hline Control & $\mathbf{8 . 7 0}$ & $\mathbf{8 . 2 4}$ & 21.0 \\
0.479 & 9.06 & 8.27 & 20.2 \\
0.879 & 8.54 & 8.24 & 19.7 \\
1.27 & 8.74 & 8.21 & 19.7 \\
1.79 & 8.72 & 8.21 & 20.7 \\
2.26 & 8.61 & 8.21 & 20.9 \\
\hline
\end{tabular}

48-Hour Readings

\begin{tabular}{cccc}
\hline $\begin{array}{c}\text { Concentration } \\
(\mathrm{g} / \mathrm{L})\end{array}$ & $\begin{array}{c}\text { DO } \\
(\mathrm{mg} / \mathrm{L})\end{array}$ & $\mathrm{pH}$ & $\begin{array}{c}\text { Temperature } \\
\left({ }^{\circ} \mathrm{C}\right)\end{array}$ \\
\hline Control & 8.88 & 8.34 & 20.2 \\
0.479 & 8.79 & 8.29 & 20.0 \\
0.879 & 8.66 & 8.26 & 20.1 \\
1.27 & 9.16 & 8.23 & 20.3 \\
1.79 & 9.25 & 8.21 & 20.0 \\
2.26 & 9.16 & 8.20 & 20.1 \\
\hline
\end{tabular}


APPENDIX 1 B

ACUTE TOXICITY TEST DATA:

D. ambigua AND C. dubia EXPOSED TO COPPER SULFATE 


\section{APPENDIX 1 B - ANALYTICAL CHEMISTRY DATA}

Nominal and actual concentrations of copper in solutions used for acute toxicity testing. Actual concentrations of copper were measured on initial and final test solutions for each test species. Values were determined by Trace Scan ICP.

\begin{tabular}{|c|c|c|c|c|}
\hline Test Species & $\begin{array}{c}\text { Nominal Cu } \\
\text { Concentration } \\
(\mu \mathrm{g} / \mathrm{L})\end{array}$ & $\begin{array}{c}\text { Measured Cu } \\
\text { Concentration } \\
\text { in Initial Test } \\
\text { Solutions } \\
(\mu \mathrm{g} / \mathrm{L})\end{array}$ & $\begin{array}{c}\text { Measured Cu } \\
\text { Concentration } \\
\text { in Final Test } \\
\text { Solutions } \\
(\mu \mathrm{g} / \mathrm{L})\end{array}$ & $\begin{array}{c}\text { Mean of } \\
\text { Initial and } \\
\text { Final Cu } \\
\text { Concentrations } \\
(\mu \mathrm{g} / \mathrm{L})\end{array}$ \\
\hline \multirow{4}{*}{ C. dubia } & 1 & 1.9 & 2.1 & 2.00 \\
\cline { 2 - 5 } & 2 & 3 & 3.1 & 3.05 \\
\cline { 2 - 6 } & 4 & 5.6 & 5.9 & 5.75 \\
\cline { 2 - 6 } & 6 & 8.3 & 8.4 & 8.35 \\
\cline { 2 - 6 } & 10 & 13.3 & 12.8 & 13.1 \\
\hline D. ambigua & 17 & 22.4 & 22.5 & 22.4 \\
\cline { 2 - 6 } & 1 & 1.9 & 1.9 & 1.90 \\
\cline { 2 - 6 } & 2 & 3 & 2.8 & 2.90 \\
\cline { 2 - 6 } & 6 & 5.6 & 5.6 & 5.60 \\
\cline { 2 - 6 } & 10 & 8.3 & 8.6 & 13.3 \\
\cline { 2 - 6 } & 17 & 13.3 & 13.3 & 21.8 \\
\hline
\end{tabular}

${ }^{1}$ Background $\mathrm{Cu}$ concentration was less than the detection limit $(1.0 \mu \mathrm{g} / \mathrm{L})$. 


\section{APPENDIX 1 B}

Forty-eight hour mortality observations on $C$. dubia in the copper sulfate toxicity test.

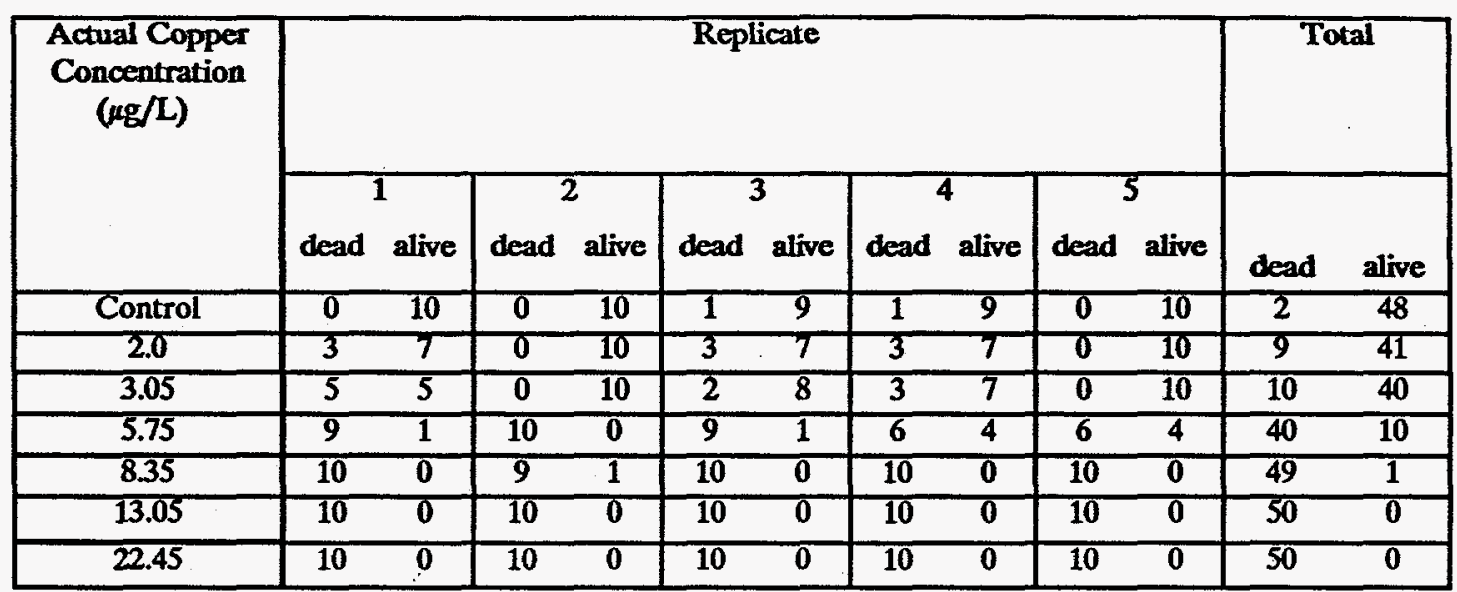

48-hour $\mathrm{LC}_{50}=4.16 \mu \mathrm{g} / \mathrm{L}(95 \%$ confidence limits $=3.70-4.69 \mu \mathrm{g} / \mathrm{L})$.

Forty-eight hour mortality observations on D. ambigua in the copper sulfate toxicity test.

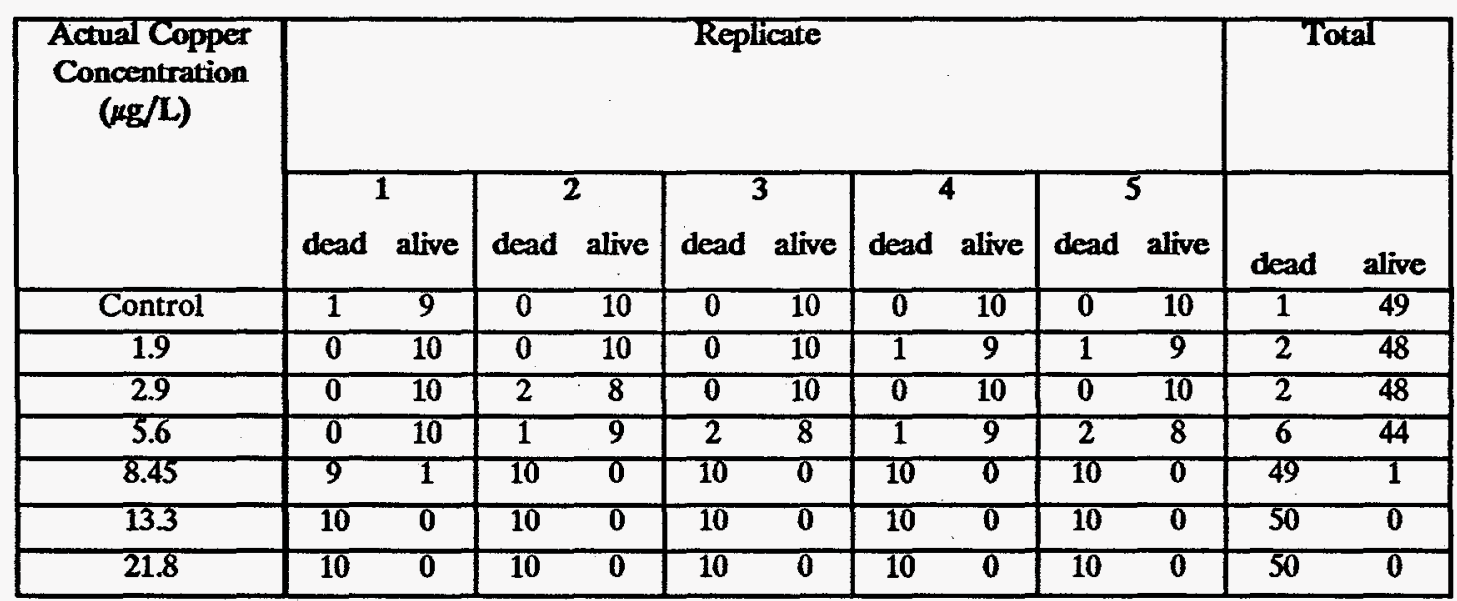

48-hour $\mathrm{LC}_{50}=6.53 \mu \mathrm{g} / \mathrm{L}(95 \%$ confidence limits $=6.17-6.93 \mu \mathrm{g} / \mathrm{L})$. 
Summary of statistical analysis for the C. dubia 48-hour acute test with copper.

\section{CT-TOX MULTI-METHOD PROGRAM}

Binomial, Moving average, Probit, and Spearman-Karber Methods

TEST SUMMARY

DATE: 6-16-97

DURATION: 48 hours

SAMPLE: copper

SPECIES: Ceriodaphnia dubia

\begin{tabular}{|l|c|c|c|c|}
\hline \multirow{2}{*}{ METHOD } & \multirow{2}{*}{ LC50 } & \multicolumn{3}{|c|}{ CONFIDENCE LIMTTS } \\
\cline { 3 - 5 } & & LOWER & UPPER & SPAN \\
\hline Binomial & 4.188 & 3.050 & 4.750 & 2.700 \\
\hline MAA & $* * * *$ & $* * * *$ & $* * * *$ & $* * * *$ \\
\hline Probit & $* * * *$ & $* * * *$ & $* * * *$ & $* * * *$ \\
\hline Spearman-Karber & 4.163 & 3.699 & 4.865 & 0.986 \\
\hline
\end{tabular}

${ }^{* * * *}=$ Limit does not exist.

TRIMMED SPEARMAN-KARBER SUMMARY

Trim:

$18.00 \%$

LC50:

4.163

95\% Lower confidence:

3.699

95\% Upper confidence:

4.685

BINOMIAL METHOD

\begin{tabular}{|c|c|c|c|l|}
\hline $\begin{array}{c}\text { Concentration } \\
(\mu \mathrm{g} / \mathrm{L})\end{array}$ & $\begin{array}{c}\text { Number } \\
\text { Exposed }\end{array}$ & $\begin{array}{c}\text { Number } \\
\text { Dead }\end{array}$ & $\begin{array}{c}\text { Percent } \\
\text { Dead }\end{array}$ & $\begin{array}{c}\text { Binomial } \\
\text { Probability }(\%)\end{array}$ \\
\hline 2.00 & 50 & 9 & 18 & $.2807 \mathrm{D}-03$ \\
\hline 3.05 & 50 & 10 & 20 & $.1193 \mathrm{D}-02$ \\
\hline 5.75 & 50 & 40 & 80 & $.1193 \mathrm{D}-02$ \\
\hline 8.35 & 50 & 49 & 98 & $.4530 \mathrm{D}-11$ \\
\hline 13.05 & 50 & 50 & 100 & $.8882 \mathrm{D}-13$ \\
\hline 22.45 & 50 & 50 & 100 & $.8882 \mathrm{D}-13$ \\
\hline
\end{tabular}

The binomial test shows that 3.05 and 5.75 can be statistically sound conservative 95 percent confidence limits since the actual confidence level associated with these limits is 99.9976 percent.

AN APPROXIMATE LC50 FOR THIS DATA SET IS 4.188

C. dubia Copper acute 


\section{MOVING AVERAGE METHOD}

The moving average method cannot be used with this data set because no span which produces average angles bracketing 45 degrees also uses two percent dead between 0 and 100 percent.

\section{PROBIT METHOD}

No convergence in 25 iterations. Probit method probably cannot be use with this set of data. 
Summary of statistical analysis for the D. ambigua 48-hour acute test with copper.

\section{CT-TOX MULTI-METHOD PROGRAM \\ Binomial, Moving average, Probit, and Spearman-Karber Methods}

TEST SUMMARY

DATE: 6-16-97

DURATION: 48 hours

SAMPLE: Copper sulfate

SPECIES: Daphnia ambigua

\begin{tabular}{|l|c|c|c|c|}
\hline \multirow{2}{*}{ METHOD } & \multirow{2}{*}{ LC50 } & \multicolumn{3}{|c|}{ CONFIDENCE LIMITS } \\
\cline { 3 - 5 } & & LOWER & UPPER & SPAN \\
\hline Binomial & 6.618 & 5.600 & 8.450 & 2.850 \\
\hline MAA & 5.545 & 4.920 & 6.202 & 1.282 \\
\hline Probit & 6.000 & $* * * *$ & $* * * *$ & $* * * *$ \\
\hline Spearman-Karber & 6.538 & 6.172 & 6.925 & 0.753 \\
\hline
\end{tabular}

**** $=$ Limit does not exist.

TRIMMED SPEARMAN-KARBER SUMMARY

Trim:

$4 \%$

LC50:

6.538

95\% Lower confidence: $\quad 6.172$

95\% Upper confidence: $\quad 6.925$

BINOMIAL METHOD

\begin{tabular}{|c|c|c|c|l|}
\hline $\begin{array}{c}\text { Concentration } \\
(\mu \mathrm{g} / \mathrm{L})\end{array}$ & $\begin{array}{c}\text { Number } \\
\text { Exposed }\end{array}$ & $\begin{array}{c}\text { Number } \\
\text { Dead }\end{array}$ & $\begin{array}{c}\text { Percent } \\
\text { Dead }\end{array}$ & $\begin{array}{c}\text { Binomial } \\
\text { Probability }(\%)\end{array}$ \\
\hline 1.9 & 50 & 2 & 4 & $.1133 \mathrm{D}-09$ \\
\hline 2.9 & 50 & 2 & 4 & $.1133 \mathrm{D}-09$ \\
\hline 5.6 & 50 & 6 & 12 & $.1622 \mathrm{D}-05$ \\
\hline 8.45 & 50 & 49 & 98 & $.4530 \mathrm{D}-11$ \\
\hline 13.3 & 50 & 50 & 100 & $.8882 \mathrm{D}-13$ \\
\hline 21.8 & 50 & 50 & 100 & $.8882 \mathrm{D}-13$ \\
\hline
\end{tabular}

The binomial test shows that 5.60 and 8.45 can be statistically sound conservative 95 percent confidence limits since the actual confidence level associated with these limits is 100.000 percent. An approximate LC50 for this data set is 6.618 . 
RESULTS USING MOVING AVERAGE

Span G LC50 95\% Confidence limit

$\begin{array}{lllll}5 & .0233 & 5.54 & 4.92 & 6.20\end{array}$

RESULTS CALCULATED BY PROBIT METHOD

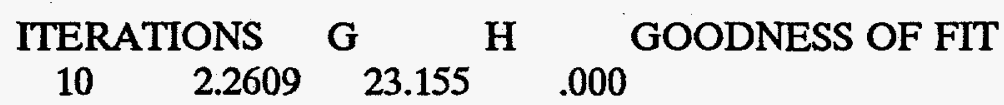

A probability of 0 means less than 0.001

SLOPE $=6.08$

95\% CONFIDENCE LIMITS: $\quad-3.06$ AND $\quad 15.23$

$\mathrm{LC} 50=6.00$

95\% CONFIDENCE LIMITS: 0 AND + INFINITY

$\mathrm{LC1}=2.49$

95\% CONFIDENCE LIMITS: 0 AND 5.04 
TEST:

Start Date:

Copper sulfate with $C$. dubia

6/14/97

Initial Water Chemistry

\begin{tabular}{|c|c|c|c|c|c|c|}
\hline $\begin{array}{c}\text { Concentration } \\
\text { (ug/L) }\end{array}$ & $\begin{array}{c}\text { DO } \\
(\mathrm{mg} / \mathrm{L})\end{array}$ & $\mathbf{p H}$ & $\begin{array}{c}\text { Temperature } \\
\left({ }^{\circ} \mathrm{C}\right) \\
\end{array}$ & $\begin{array}{c}\text { Conductivity } \\
(\mathrm{ms} / \mathrm{cm})\end{array}$ & $\begin{array}{c}\text { Alkalinity } \\
\left(\mathrm{mg} / \mathrm{L} \text { as } \mathrm{CaCO}_{3}\right)\end{array}$ & $\begin{array}{c}\text { Hardness } \\
\left(\mathrm{mg} / \mathrm{L} \text { as } \mathrm{CaCO}_{3}\right)\end{array}$ \\
\hline Control & 7.70 & 8.28 & 24.8 & 0.263 & 60 & 66 \\
\hline 2 & 7.88 & 8.28 & 25.6 & 0.265 & & \\
\hline 3.05 & 7.87 & 8.28 & 24.7 & 0.268 & & \\
\hline 5.75 & 7.84 & 8.23 & 25.6 & 0.270 & & \\
\hline 8.35 & 7.50 & 8.21 & 24.4 & 0.270 & & \\
\hline 13.05 & 8.11 & 8.16 & 24.6 & 0.270 & & \\
\hline 22.45 & 8.24 & 8.16 & 24.3 & 0.27 & 60 & 70 \\
\hline
\end{tabular}

24-Hour Readings

\begin{tabular}{cccc}
\hline $\begin{array}{c}\text { Concentration } \\
\text { (ug/L) }\end{array}$ & $\begin{array}{c}\text { DO } \\
(\mathbf{m g} / \mathrm{L})\end{array}$ & pH & $\begin{array}{c}\text { Temperature } \\
\left({ }^{\circ} \mathrm{C}\right)\end{array}$ \\
\hline Control & 8.08 & 8.37 & 24.1 \\
2 & 7.74 & 8.39 & 25.7 \\
3.05 & 7.73 & 8.41 & 25.2 \\
5.75 & 7.91 & 8.42 & 25.0 \\
8.35 & 7.96 & 8.48 & 24.9 \\
13.05 & 8.14 & 8.45 & 24.9 \\
22.45 & 7.99 & 8.42 & 24.8 \\
\hline
\end{tabular}

48-Hour Readings

\begin{tabular}{cccc}
\hline $\begin{array}{c}\text { Concentration } \\
\text { (ug/L) }\end{array}$ & $\begin{array}{c}\text { DO } \\
(\mathbf{m g} / \mathrm{L})\end{array}$ & pH & $\begin{array}{c}\text { Temperature } \\
\left({ }^{\circ} \mathrm{C}\right)\end{array}$ \\
\hline Control & 7.66 & 8.51 & 24.3 \\
2 & 7.53 & 8.43 & 25.2 \\
3.05 & 7.74 & 8.46 & 25.3 \\
5.75 & 7.72 & 8.47 & 25.2 \\
8.35 & 7.42 & 8.60 & 25.3 \\
13.05 & 8.02 & 8.55 & 24.2 \\
22.45 & 7.91 & 8.51 & 24.3 \\
\hline
\end{tabular}


TEST:

Copper sulfate with $D$. ambigua

Start Date: 6/14/97

Initial Water Chemistry

\begin{tabular}{|c|c|c|c|c|c|c|}
\hline $\begin{array}{c}\text { Concentration } \\
\text { (ug/L) }\end{array}$ & $\begin{array}{c}\mathrm{DO} \\
(\mathrm{mg} / \mathrm{L}) \\
\end{array}$ & pH & $\begin{array}{c}\text { Temperature } \\
\left({ }^{\circ} \mathrm{C}\right) \\
\end{array}$ & $\begin{array}{c}\text { Conductivity } \\
(\mathrm{ms} / \mathrm{cm})\end{array}$ & $\begin{array}{c}\text { Alkalinity } \\
\left(\mathrm{mg} / \mathrm{L} \text { as } \mathrm{CaCO}_{3}\right)\end{array}$ & $\begin{array}{c}\text { Hardness } \\
\left(\mathrm{mg} / \mathrm{L} \text { as } \mathrm{CaCO}_{3}\right)\end{array}$ \\
\hline Control & 8.52 & 8.17 & 21.1 & 0.263 & 60 & 68 \\
\hline 1.9 & 8.31 & 8.19 & 21.1 & 0.266 & & \\
\hline 2.9 & 8.42 & 8.22 & 21.9 & 0.268 & & \\
\hline 5.6 & 8.39 & 8.21 & 22.0 & 0.269 & & \\
\hline 8.45 & 8.48 & 8.17 & 21.9 & 0.270 & & \\
\hline 13.3 & 8.27 & 8.16 & 21.8 & 0.270 & & \\
\hline 21.8 & 8.40 & 8.14 & 21.9 & 0.270 & 60 & 72 \\
\hline
\end{tabular}

\section{4-Hour Readings}

\begin{tabular}{cccc}
\hline $\begin{array}{c}\text { Concentration } \\
\text { (ug/L) }\end{array}$ & $\begin{array}{c}\text { DO } \\
(\mathbf{m g} / \mathrm{L})\end{array}$ & $\mathbf{p H}$ & $\begin{array}{c}\text { Temperature } \\
\left({ }^{\circ} \mathrm{C}\right)\end{array}$ \\
\hline Control & 9.05 & 8.35 & 20.9 \\
1.9 & 8.58 & 8.31 & 20.5 \\
2.9 & 8.84 & 8.32 & 21.4 \\
5.6 & 9.04 & 8.30 & 21.2 \\
8.45 & 8.95 & 8.31 & 21.3 \\
13.3 & 8.78 & 8.30 & 21.1 \\
21.8 & 8.90 & 8.31 & 21.1 \\
\hline
\end{tabular}

48-Hour Readings

\begin{tabular}{cccc}
\hline $\begin{array}{c}\text { Concentration } \\
\text { (ug/L) }\end{array}$ & $\begin{array}{c}\text { DO } \\
(\mathbf{m g} / \mathrm{L})\end{array}$ & $\mathbf{p H}$ & $\begin{array}{c}\text { Temperature } \\
\left({ }^{\circ} \mathrm{C}\right)\end{array}$ \\
\hline Control & 8.84 & 8.41 & 21.0 \\
1.9 & 7.82 & 8.35 & 21.2 \\
2.9 & 8.55 & 8.37 & 21.3 \\
5.6 & 8.74 & 8.37 & 21.1 \\
8.45 & 8.90 & 8.36 & 20.7 \\
13.3 & 8.71 & 8.32 & 21.3 \\
21.8 & 8.79 & 8.32 & 21.2 \\
\hline
\end{tabular}


APPENDIX $1 \mathrm{C}$

ACUTE TOXICITY TEST DATA:

D. ambigua AND C. dubia EXPOSED TO SODIUM LAURYL SULFATE 


\section{APPENDIX 1 C - ANALYTICAL CHEMISTRY DATA}

Nominal and actual concentrations of sodium lauryl sulfate in solutions used for acute toxicity testing. Actual concentrations were measured on initial test solutions and are applicable to the testing for both species. Values were determined by the MBAS method (USEPA, 1983).

\begin{tabular}{|c|c|}
\hline $\begin{array}{c}\text { Nominal SLS } \\
\text { Concentration } \\
(\mathrm{mg} / \mathrm{L})\end{array}$ & $\begin{array}{c}\text { Actual SLS } \\
\text { Concentration } \\
(\mathrm{mg} / \mathrm{L})\end{array}$ \\
\hline Background & $<$ detection limit \\
\hline 1 & 0.953 \\
\hline 2 & 1.92 \\
\hline 3 & 2.9 \\
\hline 4 & 4.08 \\
\hline 6 & 6.15 \\
\hline
\end{tabular}




\section{APPENDIX $1 \mathrm{C}$}

Forty-eight hour mortality observations on $C$. dubia in the sodium lauryl sulfate toxicity test.

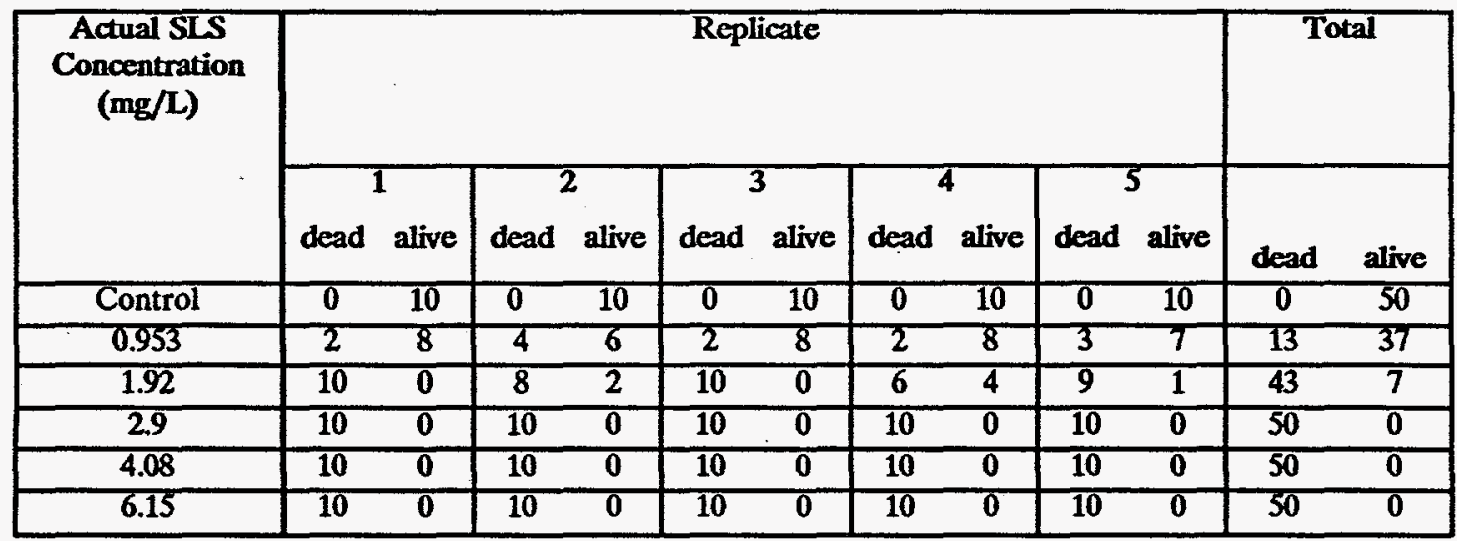

48-hour $\mathrm{LC}_{50}=1.26 \mathrm{mg} / \mathrm{L} \cdot(95 \%$ confidence limits $=1.14-1.39 \mathrm{mg} / \mathrm{L})$.

Forty-eight hour mortality observations on $D$. ambigua in the sodium lauryl sulfate toxicity test.

\begin{tabular}{|c|c|c|c|c|c|c|c|}
\hline \multirow{2}{*}{$\begin{array}{l}\text { Actual SLS } \\
\text { Concentration } \\
(\mathrm{mg} / \mathrm{L})\end{array}$} & \multicolumn{5}{|c|}{ Replicate } & \multicolumn{2}{|c|}{ Total } \\
\hline & $\begin{array}{c}1 \\
\text { dead alive }\end{array}$ & $\begin{array}{c}2 \\
\text { dead alive }\end{array}$ & $\begin{array}{c}3 \\
\text { dead alive }\end{array}$ & $\begin{array}{c}4 \\
\text { dead alive }\end{array}$ & $\begin{array}{c}5 \\
\text { dead alive }\end{array}$ & dead & alive \\
\hline Control & 10 & 10 & 10 & 10 & 10 & 0 & 50 \\
\hline 0.953 & 10 & 10 & 10 & 10 & 10 & 0 & 50 \\
\hline 1.92 & 2 & 10 & 6 & 4 & 9 & 11 & 39 \\
\hline 2.9 & 7 & 3 & 6 & 6 & 3 & 33 & 17 \\
\hline 4.08 & 9 & 10 & 9 & 9 & 10 & 47 & 3 \\
\hline 6.15 & 10 & 9 & 10 & 10 & 10 & 49 & 1 \\
\hline
\end{tabular}

48-hour $\mathrm{LC}_{50}=2.44 \mathrm{mg} / \mathrm{L}(95 \%$ confidence limits $=2.23-2.67 \mathrm{mg} / \mathrm{L})$. 
Summary of statistical analysis for the $C$. dubia 48-hour acute test with sodium lauryl sulfate.

\section{CT-TOX MULTI-METHOD PROGRAM}

Binomial, Moving average, Probit, and Spearman-Karber Methods

\section{TEST SUMMARY}

DATE: $7-2-97$

DURATION: 48 hours

SAMPLE: SLS

SPECIES: Ceriodaphnia dubia

\begin{tabular}{|l|c|c|c|c|}
\hline \multirow{2}{*}{ METHOD } & \multirow{2}{*}{ LC50 } & \multicolumn{3}{c|}{ CONFIDENCE LIMITS } \\
\cline { 3 - 5 } & & LOWER & UPPER & SPAN \\
\hline Binomial & 1.245 & 0.950 & 1.920 & 0.970 \\
\hline MAA & $* * * *$ & $* * * *$ & $* * * *$ & $* * * *$ \\
\hline Probit & $* * * *$ & $* * * *$ & $* * * *$ & $* * * *$ \\
\hline Spearman-Karber & 1.259 & 1.140 & 1.389 & 0.249 \\
\hline
\end{tabular}

**** = Limit does not exist.

TRIMMED SPEARMAN-KARBER SUMMARY

Trim: $\quad 26 \%$

LC50: $\quad 1.259$

95\% Lower confidence: $\quad 1.140$

95\% Upper confidence: $\quad 1.389$

BINOMIAL METHOD

\begin{tabular}{|c|c|c|c|l|}
\hline $\begin{array}{c}\text { Concentration } \\
(\mu \mathrm{g} / \mathrm{L})\end{array}$ & $\begin{array}{c}\text { Number } \\
\text { Exposed }\end{array}$ & $\begin{array}{c}\text { Number } \\
\text { Dead }\end{array}$ & $\begin{array}{c}\text { Percent } \\
\text { Dead }\end{array}$ & $\begin{array}{c}\text { Binomial } \\
\text { Probability }(\%)\end{array}$ \\
\hline 0.95 & 50 & 13 & 26 & $.4681 \mathrm{D}-01$ \\
\hline 1.92 & 50 & 43 & 86 & $.1049 \mathrm{D}-04$ \\
\hline 2.90 & 50 & 50 & 100 & $.8882 \mathrm{D}-13$ \\
\hline 4.08 & 50 & 50 & 100 & $.8882 \mathrm{D}-13$ \\
\hline 6.15 & 50 & 50 & 100 & $.8882 \mathrm{D}-13$ \\
\hline
\end{tabular}

The binomial test shows that 0.95 and 1.92 can be statistically sound conservative 95 percent confidence limits since the actual confidence level associated with these limits is 99.9532 percent.

An approximate LC50 for this data set is $\mathbf{1 . 2 4 5}$. 
MOVING AVERAGE METHOD

The moving average method cannot be used with this data set because no span which produces average angles bracketing 45 degrees also uses two percent dead between 0 and 100 percent.

\section{RESULTS CALCULATED BY PROBIT METHOD}

No convergence in 25 iterations. Probit method probably can not be use with this set of data. 
Summary of statistical analysis for the D. ambigua 48-hour acute test with sodium lauryl sulfate.

\section{CT-TOX MULTI-METHOD PROGRAM}

Binomial, Moving average, Probit, and Spearman-Karber Methods

TEST SUMMARY

DATE: 7-2-97

DURATION: 48 hours

SAMPLE: sodium lauryl sulfate SPECIES: Daphnia ambigua

\begin{tabular}{|l|c|c|c|c|}
\hline \multirow{2}{*}{ METHOD } & \multirow{2}{*}{ LC50 } & \multicolumn{3}{|c|}{ CONFIDENCE LIMITS } \\
\cline { 3 - 5 } & & LOWER & UPPER & SPAN \\
\hline Binomial & 2.506 & 1.920 & 2.900 & 0.980 \\
\hline MAA & 2.376 & 2.128 & 2.621 & 0.493 \\
\hline Probit & 2.513 & 2.300 & 2.723 & 0.423 \\
\hline Spearman-Karber & 2.436 & 2.226 & 2.665 & 0.440 \\
\hline
\end{tabular}

**** $=$ Limit does not exist.

TRIMMED SPEARMAN-KARBER SUMMARY

Trim: $\quad 2 \%$

LC50: $\quad 2.436$

95\% Lower confidence: $\quad 2.226$

95\% Upper confidence: $\quad 2.665$

BINOMIAL METHOD

\begin{tabular}{|c|c|c|c|l|}
\hline $\begin{array}{c}\text { Concentration } \\
(\mathrm{mg} / \mathrm{L})\end{array}$ & $\begin{array}{c}\text { Number } \\
\text { Exposed }\end{array}$ & $\begin{array}{c}\text { Number } \\
\text { Dead }\end{array}$ & $\begin{array}{c}\text { Percent } \\
\text { Dead }\end{array}$ & $\begin{array}{c}\text { Binomial } \\
\text { Probability (\%) }\end{array}$ \\
\hline 0.95 & 50 & 0 & 0 & $.8882 \mathrm{D}-13$ \\
\hline 1.92 & 50 & 11 & 22 & $.4511 \mathrm{D}-02$ \\
\hline 2.90 & 50 & 33 & 66 & $.1642 \mathrm{D}+01$ \\
\hline 4.08 & 50 & 47 & 94 & $.1854 \mathrm{D}-08$ \\
\hline 6.15 & 50 & 49 & 98 & $.4530 \mathrm{D}-11$ \\
\hline
\end{tabular}

The binomial test shows that 1.92 and 2.90 can be statistically sound conservative 95 percent confidence limits since the actual confidence level associated with these limits is 98.3535 percent. An approximate LC50 for this data set is 2.506 . 


\section{RESULTS USING MOVING AVERAGE \\ Span G LC50 95\% Confidence limit \\ $\begin{array}{lllll}4 & .0292 & 2.38 & 2.13 & 2.62\end{array}$}

\section{RESULTS CALCULATED BY PROBIT METHOD}

\begin{tabular}{crrrr}
\multicolumn{2}{c}{ ITERATIONS } & G & H & GOODNESS OF FIT \\
5 & .0540 & 1.000 & .505 &
\end{tabular}

SLOPE $=6.50$

95\% CONFIDENCE LIMITS: 4.99 AND 8.01

$\mathrm{LC} 50=2.51$

95\% CONFIDENCE LIMITS: 2.30 AND 2.72

$\mathbf{L C} 1=1.10$

95\% CONFIDENCE LIMIT: $\quad .83$ AND 1.32 
TEST: $\quad$ Sodium lauryl sulfate with $C$. dubia

Start Date: $\quad$ 6/30/97

Initial Water Chemistry

\begin{tabular}{ccccccc}
\hline $\begin{array}{c}\text { Concentration } \\
(\mathrm{mg} / \mathrm{L})\end{array}$ & $\begin{array}{c}\text { DO } \\
(\mathbf{m g} / \mathrm{L})\end{array}$ & $\mathrm{pH}$ & $\begin{array}{c}\text { Temperature } \\
\left({ }^{\circ} \mathrm{C}\right)\end{array}$ & $\begin{array}{c}\text { Conductivity } \\
(\mathrm{ms} / \mathrm{cm})\end{array}$ & $\begin{array}{c}\text { Alkalinity } \\
\left(\mathrm{mg} / \mathrm{L} \text { as } \mathrm{CaCO}_{3}\right)\end{array}$ & $\begin{array}{c}\text { Hardness } \\
\left(\mathrm{mg} / \mathrm{L} \mathrm{as} \mathrm{CaCO}_{3}\right)\end{array}$ \\
\hline Control & 7.91 & 8.28 & 24.5 & 0.286 & 65 & 72 \\
0.953 & 7.84 & 8.21 & 24.2 & 0.286 & & \\
1.92 & 8.23 & 8.31 & 24.3 & 0.285 & & \\
2.9 & 8.02 & 8.31 & 24.4 & 0.281 & & \\
4.08 & 8.41 & 8.25 & 24.2 & 0.289 & 60 & 80 \\
6.15 & 8.40 & 8.16 & 24.6 & 0.294 & 60 & \\
\hline
\end{tabular}

24-Hour Readings

\begin{tabular}{cccc}
\hline $\begin{array}{c}\text { Concentration } \\
(\mathrm{mg} / \mathrm{L})\end{array}$ & $\begin{array}{c}\text { DO } \\
(\mathrm{mg} / \mathrm{L})\end{array}$ & $\mathbf{p H}$ & $\begin{array}{c}\text { Temperature } \\
\left({ }^{\circ} \mathrm{C}\right)\end{array}$ \\
\hline Control & 9.00 & 8.66 & 24.8 \\
0.953 & 8.28 & 8.49 & 24.1 \\
1.92 & 8.62 & 8.49 & 24.0 \\
2.9 & 7.97 & 8.46 & 24.1 \\
4.08 & 8.45 & 8.60 & 24.3 \\
6.15 & 8.05 & 8.60 & 24.3 \\
\hline
\end{tabular}

48-Hour Readings

\begin{tabular}{cccc}
\hline $\begin{array}{c}\text { Concentration } \\
(\mathrm{mg} / \mathrm{L})\end{array}$ & $\begin{array}{c}\text { DO } \\
(\mathbf{m g} / \mathrm{L})\end{array}$ & pH & $\begin{array}{c}\text { Temperature } \\
\left({ }^{\circ} \mathrm{C}\right)\end{array}$ \\
\hline Control & 8.65 & 8.36 & 24.8 \\
0.953 & 8.76 & 8.37 & 24.8 \\
1.92 & 8.65 & 8.33 & 25.0 \\
2.9 & 8.65 & 8.36 & 25.1 \\
4.08 & 8.32 & 8.38 & 24.9 \\
6.15 & 8.25 & 8.31 & 24.7 \\
\hline
\end{tabular}


TEST: $\quad$ Sodium lauryl sulfate with $D$. ambigua

Start Date: $\quad 3 / 30 / 97$

Initial Water Chemistry

\begin{tabular}{ccccccc}
\hline $\begin{array}{c}\text { Concentration } \\
(\mathbf{m g} / \mathrm{L})\end{array}$ & $\begin{array}{c}\mathbf{D O} \\
(\mathbf{m g} / \mathrm{L})\end{array}$ & $\mathbf{p H}$ & $\begin{array}{c}\text { Temperature } \\
\left({ }^{\circ} \mathbf{C}\right)\end{array}$ & $\begin{array}{c}\text { Conductivity } \\
(\mathbf{m s} / \mathbf{c m})\end{array}$ & $\begin{array}{c}\text { Alkalinity } \\
\left(\mathbf{m g} / \mathbf{L} \text { as } \mathrm{CaCO}_{3}\right)\end{array}$ & $\begin{array}{c}\text { Hardness } \\
\left(\mathbf{m g} / \mathbf{L} \text { as } \mathbf{C a C O}_{3}\right)\end{array}$ \\
\hline Control & 7.46 & 8.25 & 21.2 & 0.267 & 64 & 66 \\
0.953 & 7.81 & 8.23 & 21.3 & 0.267 & & \\
1.92 & 7.53 & 8.28 & 21.4 & 0.268 & & \\
2.9 & 7.61 & 8.21 & 21.4 & 0.274 & & \\
4.08 & 8.32 & 8.11 & 21.4 & 0.275 & & \\
6.15 & 8.73 & 8.05 & 21.4 & 0.289 & 60 & \\
\hline
\end{tabular}

\section{4-Hour Readings}

\begin{tabular}{cccc}
\hline $\begin{array}{c}\text { Concentration } \\
(\mathbf{m g} / \mathbf{L})\end{array}$ & $\begin{array}{c}\text { DO } \\
(\mathbf{m g} / \mathbf{L})\end{array}$ & $\mathbf{p H}$ & $\begin{array}{c}\text { Temperature } \\
\left({ }^{\circ} \mathrm{C}\right)\end{array}$ \\
\hline Control & 8.23 & 8.34 & 20.8 \\
0.953 & 9.14 & 8.34 & 20.8 \\
1.92 & 9.11 & 8.33 & 20.9 \\
2.9 & 9.11 & 8.32 & 20.8 \\
4.08 & 8.87 & 8.30 & 21.3 \\
6.15 & 9.00 & 8.34 & 20.9 \\
\hline
\end{tabular}

48-Hour Readings

\begin{tabular}{cccc}
\hline $\begin{array}{c}\text { Concentration } \\
(\mathbf{m g} / \mathrm{L})\end{array}$ & $\begin{array}{c}\text { DO } \\
(\mathbf{m g} / \mathrm{L})\end{array}$ & $\mathbf{p H}$ & $\begin{array}{c}\text { Temperature } \\
\left({ }^{\circ} \mathrm{C}\right)\end{array}$ \\
\hline Control & 8.75 & 8.35 & 21.2 \\
0.953 & 8.85 & 8.35 & 21.3 \\
1.92 & 8.87 & 8.34 & 21.5 \\
2.9 & 8.64 & 8.33 & 21.1 \\
4.08 & 9.01 & 8.30 & 21.1 \\
6.15 & 8.96 & 8.30 & 21.0 \\
\hline
\end{tabular}




\section{APPENDIX 1 D}

ACUTE TOXICITY TEST DATA:

D. ambigua AND C. dubia EXPOSED TO CHLORPYRIFOS 


\section{APPENDIX 1 D - ANALYTICAL CHEMISTRY DATA}

Nominal and actual concentrations of chlorpyrifos in solutions used for acute toxicity testing. Values were determined by solid-phase microextraction and GC/MS.

\begin{tabular}{|c|c|c|c|c|c|}
\hline $\begin{array}{c}\text { Test } \\
\text { Species }\end{array}$ & $\begin{array}{c}\text { Nominal } \\
\text { Chlorpyrifos } \\
\text { Concentration } \\
(\mu \mathrm{g} / \mathrm{L})\end{array}$ & $\begin{array}{c}\text { Measured } \\
\text { Chlorpyrifos } \\
\text { Concentration } \\
\text { in Initial Test } \\
\text { Solutions } \\
(\mu \mathrm{g} / \mathrm{L})\end{array}$ & $\begin{array}{c}\text { Measured } \\
\text { Chlorpyrifos } \\
\text { Concentration } \\
\text { in Mid-point } \\
\text { Test Solutions } \\
(\mu \mathrm{g} / \mathrm{L})\end{array}$ & $\begin{array}{c}\text { Measured } \\
\text { Chlorpyrifos } \\
\text { Concentration } \\
\text { in Final Test } \\
\text { Solutions } \\
(\mu \mathrm{g} / \mathrm{L})\end{array}$ & $\begin{array}{c}\text { Geometric } \\
\text { Mean of } \\
\text { Chlorpyrifos } \\
\text { Concentrations } \\
(\mu \mathrm{g} / \mathrm{L})\end{array}$ \\
\hline C. dubia & 0.075 & 0.0558 & 0.0202 & 0.0236 & 0.030 \\
\cline { 2 - 6 } & 0.1 & 0.1288 & 0.0333 & 0.0206 & 0.044 \\
\cline { 2 - 6 } & 0.2 & 0.2182 & 0.0222 & 0.0729 & 0.071 \\
\cline { 2 - 6 } & 0.5 & 0.5847 & 0.0433 & 0.0218 & 0.082 \\
\hline \multirow{5yyyyy}{*}{ D. ambigua } & 0.9 & 0.8304 & 0.0843 & 0.0917 & 0.185 \\
\cline { 2 - 6 } & 0.0125 & 0.0185 & 0.0173 & 0.0116 & 0.015 \\
\cline { 2 - 6 } & 0.025 & 0.0288 & 0.0428 & 0.0312 & 0.033 \\
\cline { 2 - 6 } & 0.05 & 0.0566 & 0.0436 & 0.0176 & 0.035 \\
\cline { 2 - 6 } & 0.075 & 0.1024 & 0.0662 & 0.0355 & 0.062 \\
\hline
\end{tabular}

Chlorpyrifos concentrations decreased notably in 24 and 48-hour readings, probably due to the volatile nature of the compound, thus the decrease was more evident in the $C$. dubia test which was conducted at $\times$ a higher temperature than the $D$. ambigua test $\left(25^{\circ} \mathrm{C}\right.$ vs. $\left.21^{\circ} \mathrm{C}\right)$. Therefore, the $\mathrm{LC}_{50}$ s for each species were relatively close, even though nominal test concentrations and nominal $\mathrm{LC}_{50}$ values were quite different. Actual concentrations were determined by taking the geometric mean of the three analytical values. 


\section{APPENDIX 1 D}

Forty-eight hour mortality observations on $C$. dubia in the chlorpyrifos toxicity test.

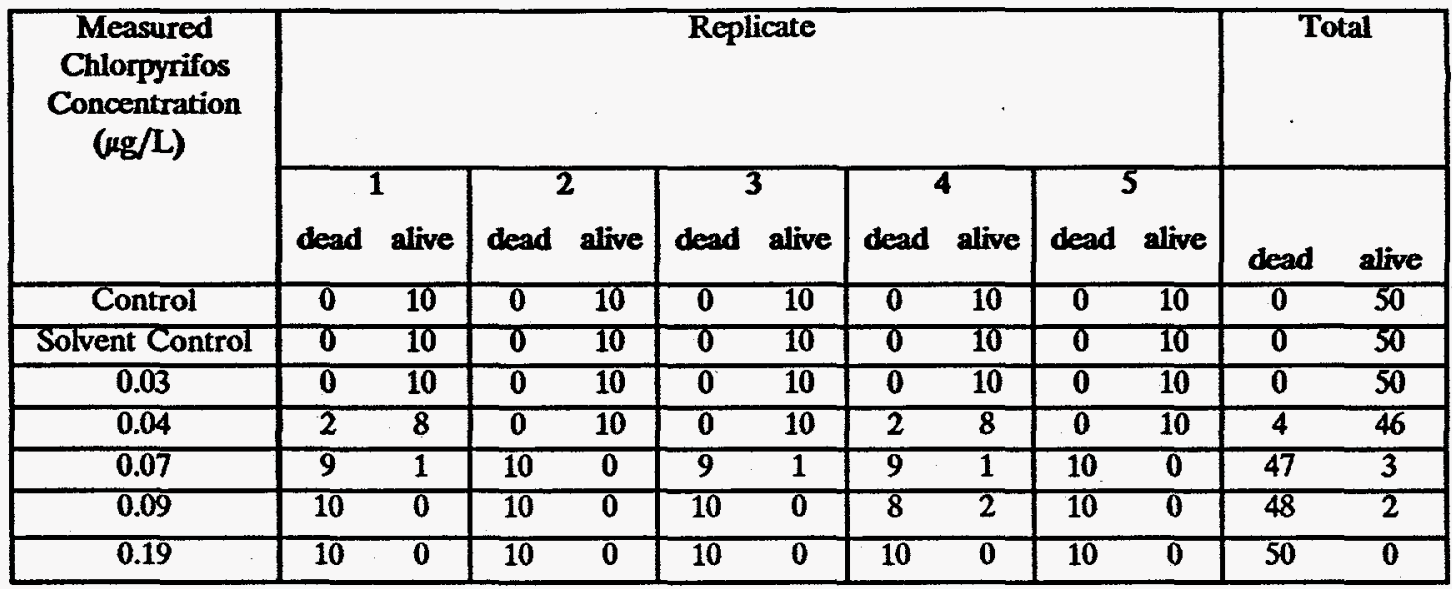

48-hour $\mathrm{LC}_{50}=0.056 \mu \mathrm{g} / \mathrm{L}(95 \%$ confidence limits $=0.054-0.059 \mu \mathrm{g} / \mathrm{L})$.

Forty-eight hour mortality observations on $D$. ambigua in the chlorpyrifos toxicity test.

\begin{tabular}{|c|c|c|c|c|c|c|c|c|c|c|c|c|}
\hline \multirow{3}{*}{$\begin{array}{l}\text { Chlorpyrifos } \\
\text { Concentration } \\
(\mu \mathrm{g} / \mathrm{L})\end{array}$} & \multicolumn{10}{|c|}{ Replicate } & \multicolumn{2}{|c|}{ Total } \\
\hline & \multicolumn{2}{|c|}{$\mathbf{T}$} & \multicolumn{2}{|c|}{2} & \multicolumn{2}{|c|}{3} & \multicolumn{2}{|c|}{4} & \multicolumn{2}{|c|}{5} & \multirow{2}{*}{ dead } & \multirow{2}{*}{ alive } \\
\hline & dear & alive & deac & alive & dead & alive & dear & alive & dead & alive & & \\
\hline Control & $\overline{0}$ & 10 & 0 & 10 & $\mathbf{0}$ & 10 & 0 & 10 & $T$ & 9 & 1 & 49 \\
\hline Solvent control & 0 & 10 & $\overline{0}$ & 10 & $\overline{0}$ & 10 & $\overline{0}$ & 10 & $\overline{0}$ & 10 & $\overline{0}$ & 50 \\
\hline 0.02 & 0 & 10 & $\overline{0}$ & 10 & $\overline{0}$ & 10 & $\overline{0}$ & 10 & $\overline{0}$ & 10 & $\overline{0}$ & 50 \\
\hline 0.03 & 2 & 8 & $\overline{3}$ & 7 & 1 & 9 & 1 & 9 & 2 & 8 & 9 & 41 \\
\hline 0.04 & 7 & 3 & 9 & 1 & 7 & 3 & 7 & 3 & 9 & 1 & 39 & 11 \\
\hline 0.06 & 8 & 2 & 10 & $\mathbf{0}$ & 10 & $\mathbf{0}$ & $\overline{10}$ & 0 & 9 & $\overline{1}$ & 47 & 3 \\
\hline $0.0 \overline{8}$ & 10 & 0 & 10 & $\mathbf{0}$ & 10 & $\overline{0}$ & 10 & 0 & 10 & 0 & 50 & $\mathbf{0}$ \\
\hline
\end{tabular}

48-hour $\mathrm{LC}_{50}=0.035 \mu \mathrm{g} / \mathrm{L}(95 \%$ confidence limits $=0.032-0.037 \mu \mathrm{g} / \mathrm{L})$. 
Summary of statistical analysis for the $C$. dubia 48-hour acute test with chlorpyrifos.

\section{CT-TOX MULTI-METHOD PROGRAM}

Binomial, Moving average, Probit, and Spearman-Karber Methods

TEST SUMMARY

DATE: 9-6-97

DURATION: 48 hours

SAMPLE: chlorpyrifos

SPECIES: Ceriodaphnia dubia

\begin{tabular}{|l|c|c|c|c|}
\hline \multirow{2}{*}{ METHOD } & \multirow{2}{*}{ LC50 } & \multicolumn{3}{c|}{ CONFIDENCE LIMITS } \\
\cline { 3 - 5 } & & LOWER & UPPER & SPAN \\
\hline Binomial & 0.055 & 0.044 & 0.071 & 0.027 \\
\hline MAA & $* * * *$ & $* * * *$ & $* * * *$ & $* * * *$ \\
\hline Probit & $* * * *$ & $* * * *$ & $* * * *$ & $* * * *$ \\
\hline Spearman-Karber & 0.056 & 0.054 & 0.059 & 0.006 \\
\hline
\end{tabular}

**** $=$ Limit does not exist.

TRIMMED SPEARMAN-KARBER SUMMARY

Trim:

$0 \%$

LC50:

0.055

95\% Lower confidence: $\quad 0.054$

95\% Upper confidence: $\quad 0.059$

BINOMIAL METHOD

\begin{tabular}{|c|c|c|c|l|}
\hline $\begin{array}{c}\text { Concentration } \\
(\mu \mathrm{g} / \mathrm{L})\end{array}$ & $\begin{array}{c}\text { Number } \\
\text { Exposed }\end{array}$ & $\begin{array}{c}\text { Number } \\
\text { Dead }\end{array}$ & $\begin{array}{c}\text { Percent } \\
\text { Dead }\end{array}$ & $\begin{array}{c}\text { Binomial } \\
\text { Probability }(\%)\end{array}$ \\
\hline 0.03 & 50 & 0 & 0 & $.8882 \mathrm{D}-13$ \\
\hline 0.04 & 50 & 4 & 8 & $.2231 \mathrm{D}-07$ \\
\hline 0.07 & 50 & 47 & 94 & $.1854 \mathrm{D}-08$ \\
\hline 0.09 & 50 & 48 & 96 & $.1133 \mathrm{D}-09$ \\
\hline 0.19 & 50 & 50 & 100 & $.8882 \mathrm{D}-13$ \\
\hline
\end{tabular}

The binomial test shows that 0.04 and 0.07 can be statistically sound conservative 95 percent confidence limits since the actual confidence level associated with these limits is $\mathbf{1 0 0}$ percent.

An approximate LC50 for this data set is $\mathbf{0 . 0 5 5}$. 


\section{RESULTS USING MOVING AVERAGE}

The moving average method cannot be used with this data set because no span which produces average angles bracketing 45 degrees also uses two percent dead between 0 and 100 percent.

\section{RESULTS CALCULATED BY PROBIT METHOD}

No convergence in 25 iterations. Probit method probably can not be use with this set of data. 
Summary of statistical analysis for the $D$. ambigua 48-hour acute test with chlorpyrifos.

\section{CT-TOX MULTI-METHOD PROGRAM}

Binomial, Moving average, Probit, and Spearman-Karber Methods

\section{TEST SUMMARY}

DATE: 9-10-97

DURATION: 48 hours

SAMPLE: chlorpyrifos

SPECIES: Daphnia ambigua

\begin{tabular}{|l|c|c|c|c|}
\hline \multirow{2}{*}{ METHOD } & \multirow{2}{*}{ LC50 } & \multicolumn{3}{c|}{ CONFIDENCE LIMITS } \\
\cline { 3 - 5 } & & LOWER & UPPER & SPAN \\
\hline Binomial & 0.034 & 0.033 & 0.035 & 0.002 \\
\hline MAA & 0.035 & 0.032 & 0.037 & 0.005 \\
\hline Probit & 0.035 & $* * * *$ & $* * * *$ & $* * * *$ \\
\hline Spearman-Karber & 0.035 & 0.032 & 0.037 & 0.005 \\
\hline
\end{tabular}

**** $=$ Limit does not exist.

\section{TRIMMED SPEARMAN-KARBER SUMMARY}

Trim: $\quad$ * $\quad 0 \%$

LC50: $\quad 0.035$

95\% Lower confidence: $\quad 0.032$

95\% Upper confidence: $\quad 0.037$

BINOMIAL METHOD

\begin{tabular}{|c|c|c|c|l|}
\hline $\begin{array}{c}\text { Concentration } \\
(\mu \mathrm{g} / \mathrm{L})\end{array}$ & $\begin{array}{c}\text { Number } \\
\text { Exposed }\end{array}$ & $\begin{array}{c}\text { Number } \\
\text { Dead }\end{array}$ & $\begin{array}{c}\text { Percent } \\
\text { Dead }\end{array}$ & $\begin{array}{c}\text { Binomial } \\
\text { Probability (\%) }\end{array}$ \\
\hline 0.02 & 50 & 0 & 0 & $.8882 \mathrm{D}-13$ \\
\hline 0.03 & 50 & 9 & 18 & $.2807 \mathrm{D}-03$ \\
\hline 0.04 & 50 & 39 & 78 & $.4511 \mathrm{D}-02$ \\
\hline 0.06 & 50 & 47 & 94 & $.1854 \mathrm{D}-08$ \\
\hline 0.08 & 50 & 50 & 100 & $.8882 \mathrm{D}-13$ \\
\hline
\end{tabular}

The binomial test shows that 0.03 and 0.04 can be statistically sound conservative 95 percent confidence limits since the actual confidence level associated with these limits is 99.9952 percent. An approximate LC50 for this data set is 0.034 . 
RESULTS USING MOVING AVERAGE

SPAN G LC50 $\quad 95 \%$ CONFIDENCE LIMIT

$4 \quad .0179$

.03

$.03 \quad .04$

\section{RESULTS CALCULATED BY PROBIT METHOD \\ ITERATIONS G H GOODNESS OF FIT \\ $\begin{array}{llll}5 & 2.0081 & 9.865 & .000\end{array}$}

A PROBABILITY OF 0 MEANS LESS THAN 0.001

SLOPE $=7.54$

95\% CONFIDENCE LIMITS: $\quad-3.14$ AND 18.22

$\mathrm{LC} 50=.04$

95\% CONFIDENCE LIMITS: 0 AND + INFINITY

$\mathrm{LC} 1=.02$

95\% CONFIDËNCE LIMITS: 0 AND $\quad .03$ 
TEST:

Start Date:
Chlorpyrifos with $C$. dubia

9/4/97

Initial Water Chemistry

\begin{tabular}{ccccccc}
\hline $\begin{array}{c}\text { Concentration } \\
(\mathbf{u g} / \mathrm{L})\end{array}$ & $\begin{array}{c}\mathbf{D O} \\
(\mathrm{mg} / \mathrm{L})\end{array}$ & $\mathbf{p H}$ & $\begin{array}{c}\text { Temperature } \\
\left({ }^{\circ} \mathrm{C}\right)\end{array}$ & $\begin{array}{c}\text { Conductivity } \\
(\mathrm{ms} / \mathrm{cm})\end{array}$ & $\begin{array}{c}\text { Alkalinity } \\
\left(\mathrm{mg} / \mathrm{L} \text { as } \mathrm{CaCO}_{3}\right)\end{array}$ & $\begin{array}{c}\text { Hardness } \\
\left(\mathrm{mg} / \mathrm{L} \mathrm{as} \mathbf{C a C O}_{3}\right)\end{array}$ \\
\hline Control & 7.80 & 8.47 & 24.1 & 0.256 & 54 & 56 \\
0.03 & 8.15 & 8.18 & 24.2 & 0.256 & & \\
0.044 & 7.90 & 8.18 & 24.1 & 0.256 & & \\
0.071 & 7.95 & 8.21 & 24.4 & 0.265 & & \\
0.082 & 7.97 & 8.21 & 24.2 & 0.267 & & 58 \\
0.185 & 8.07 & 8.20 & 24.4 & 0.267 & 56 & 58 \\
\hline
\end{tabular}

24-Hour Readings

\begin{tabular}{cccc}
\hline $\begin{array}{c}\text { Concentration } \\
\text { (ug/L) }\end{array}$ & $\begin{array}{c}\text { DO } \\
(\mathrm{mg} / \mathrm{L})\end{array}$ & $\mathbf{p H}$ & $\begin{array}{c}\text { Temperature } \\
\left({ }^{\circ} \mathrm{C}\right)\end{array}$ \\
\hline Control & 7.89 & 8.15 & 24.4 \\
0.03 & 7.46 & 8.26 & 24.5 \\
0.044 & 7.66 & 8.25 & 24.5 \\
0.071 & 7.72 & 8.21 & 24.5 \\
0.082 & 7.88 & 8.18 & 24.3 \\
0.185 & 7.95 & 8.20 & 24.1 \\
\hline
\end{tabular}

\section{8-Hour Readings}

\begin{tabular}{cccc}
\hline $\begin{array}{c}\text { Concentration } \\
\text { (ug/L) }\end{array}$ & $\begin{array}{c}\text { DO } \\
(\mathbf{m g} / \mathrm{L})\end{array}$ & $\mathbf{p H}$ & $\begin{array}{c}\text { Temperature } \\
\left({ }^{\circ} \mathrm{C}\right)\end{array}$ \\
\hline Control & $\mathbf{7 . 6 6}$ & 8.21 & 24.8 \\
0.03 & 7.43 & 8.27 & 25.0 \\
0.044 & 7.35 & 8.22 & 25.1 \\
0.071 & 7.65 & 8.24 & 25.1 \\
0.082 & 7.62 & 8.22 & 24.8 \\
0.185 & 7.54 & 8.18 & 24.7 \\
\hline
\end{tabular}


TEST:

Start Date:

Chlorpyrifos with $D$. ambigua

9/8/97

Initial Water Chemistry

\begin{tabular}{ccccccc}
\hline $\begin{array}{c}\text { Concentration } \\
(\mathrm{ug} / \mathrm{L})\end{array}$ & $\begin{array}{c}\mathrm{DO} \\
(\mathbf{m g} / \mathrm{L})\end{array}$ & $\mathbf{p H}$ & $\begin{array}{c}\text { Temperature } \\
\left({ }^{\circ} \mathrm{C}\right)\end{array}$ & $\begin{array}{c}\text { Conductivity } \\
(\mathbf{m s} / \mathbf{c m})\end{array}$ & $\begin{array}{c}\text { Alkalinity } \\
\left(\mathbf{m g} / \mathbf{L} \text { as } \mathrm{CaCO}_{3}\right)\end{array}$ & $\begin{array}{c}\text { Hardness } \\
\left(\mathbf{m g} / \mathbf{L} \text { as } \mathrm{CaCO}_{3}\right)\end{array}$ \\
\hline Control & 7.99 & 8.39 & 21.8 & 0.249 & 56 & 62 \\
0.015 & 8.12 & 8.26 & 21.8 & 0.250 & & \\
0.033 & 8.19 & 8.22 & 21.3 & 0.251 & & \\
0.035 & 8.44 & 8.22 & 21.8 & 0.251 & & 62 \\
0.062 & 8.38 & 8.22 & 22.0 & 0.251 & & \\
0.08 & 8.35 & 8.23 & 21.6 & 0.252 & 58 & \\
\hline
\end{tabular}

24-Hour Readings

\begin{tabular}{cccc}
\hline $\begin{array}{c}\text { Concentration } \\
\text { (ug/L) }\end{array}$ & $\begin{array}{c}\text { DO } \\
(\mathbf{m g} / \mathbf{L})\end{array}$ & $\mathbf{p H}$ & $\begin{array}{c}\text { Temperature } \\
\left({ }^{\circ} \mathrm{C}\right)\end{array}$ \\
\hline Control & 8.69 & 8.26 & 21.4 \\
0.015 & 8.66 & 8.28 & 21.2 \\
0.033 & 8.66 & 8.27 & 21.2 \\
0.035 & 8.67 & 8.25 & 21.3 \\
0.062 & 8.77 & 8.26 & 21.1 \\
0.08 & 8.74 & 8.25 & 21.2 \\
\hline
\end{tabular}

48-Hour Readings

\begin{tabular}{cccc}
\hline $\begin{array}{c}\text { Concentration } \\
(\text { ug/L) }\end{array}$ & $\begin{array}{c}\text { DO } \\
(\mathbf{m g} / \mathrm{L})\end{array}$ & $\begin{array}{c}\text { pH } \\
\text { Control }\end{array}$ & $\begin{array}{c}\text { Temperature } \\
\left({ }^{\circ} \mathrm{C}\right)\end{array}$ \\
\hline 0.015 & 8.76 & 8.27 & 21.0 \\
0.033 & 8.56 & 8.25 & 21.1 \\
0.035 & 8.55 & 8.30 & 21.3 \\
0.062 & 8.55 & 8.22 & 21.2 \\
0.08 & 8.43 & 8.24 & 21.0 \\
\hline
\end{tabular}


APPENDIX 2

CHRONIC TOXICITY TEST DATA:

GENERAL SENSITIVITY OF D. ambigua VS. C. dubia EXPOSED TO

1. SODIUM CHLORIDE

2. COPPER SULFATE 
APPENDIX 2 A

CHRONIC TOXICITY TEST DATA:

C. dubia EXPOSED TO SODIUM CHLORIDE 


\section{APPENDIX 2 - ANALYTICAL CHEMISTRY DATA - SODIUM CHLORIDE}

Nominal and actual concentrations of sodium chloride in solutions used for chronic toxicity testing. Actual concentrations of sodium were measured on three samples taken during the chronic test period. Values were determined by Trace Scan ICP.

\begin{tabular}{|c|c|c|c|c|}
\hline $\begin{array}{c}\text { Sample } \\
\text { Time }\end{array}$ & $\begin{array}{c}\text { Nominal } \mathrm{NaCl} \\
\text { Concentration } \\
(\mathrm{g} / \mathrm{L})\end{array}$ & $\begin{array}{c}\text { Measured Na } \\
\text { Concentration } \\
(\mathrm{g} / \mathrm{L})\end{array}$ & $\begin{array}{l}\text { Measured Na } \\
\text { minus } \\
\text { Background } \mathrm{Na} \\
\text { Concentration } 1 \\
(\mathrm{~g} / \mathrm{L})\end{array}$ & $\begin{array}{l}\text { Actual NaCl } \\
\text { Concentration }^{2} \\
(\mathrm{~g} / \mathrm{L})\end{array}$ \\
\hline \multirow{6}{*}{ Initial } & 0.25 & 0.108 & 0.0826 & 0.210 \\
\hline & 0.5 & 0.202 & 0.1766 & 0.450 \\
\hline & 1.0 & 0.365 & 0.3396 & 0.865 \\
\hline & 1.5 & 0.536 & 0.5106 & 1.30 \\
\hline & 2.0 & 0.714 & 0.6886 & 1.75 \\
\hline & 2.5 & 0.885 & 0.8596 & 2.19 \\
\hline \multirow[t]{6}{*}{ Mid-point } & 0.25 & 0.108 & 0.0826 & 0.210 \\
\hline & 0.5 & 0.194 & 0.1686 & 0.430 \\
\hline & 1.0 & 0.353 & 0.3276 & 0.835 \\
\hline & 1.5 & 0.531 & 0.5056 & 1.29 \\
\hline & 2.0 & 0.710 & 0.6846 & 1.74 \\
\hline & 2.5 & 0.865 & 0.8396 & 2.14 \\
\hline \multirow[t]{6}{*}{ Final } & 0.25 & 0.110 & 0.0846 & 0.215 \\
\hline & 0.5 & 0.200 & 0.1746 & 0.445 \\
\hline & 1.0 & 0.356 & 0.3306 & 0.842 \\
\hline & 1.5 & 0.535 & 0.5096 & 1.30 \\
\hline & 2.0 & 0.689 & 0.6636 & 1.69 \\
\hline & 2.5 & 0.862 & 0.8366 & 2.13 \\
\hline
\end{tabular}

${ }^{1}$ Background Na concentration $=0.0254 \mathrm{~g} / \mathrm{L}$.

${ }^{2}$ Concentration of $\mathrm{NaCl}$ was calculated using the following formula:

$[\mathrm{NaCl}]=([\mathrm{Na}] / 22.9) * 58.35$

Geometric Means of the sodium chloride concentrations.

\begin{tabular}{|c|c|c|c|c|}
\hline $\begin{array}{c}\text { Nominal NaCl } \\
\text { Concentration } \\
(\mathrm{g} / \mathrm{L})\end{array}$ & $\begin{array}{c}\text { Measured NaC } \\
\text { Concentration } \\
\text { in Initial Test } \\
\text { Solutions } \\
(\mathrm{g} / \mathrm{L})\end{array}$ & $\begin{array}{c}\text { Measured NaCl } \\
\text { Concentration in } \\
\text { Mid-way Point } \\
\text { Solutions } \\
(\mathrm{g} / \mathrm{L})\end{array}$ & $\begin{array}{c}\text { Measured NaC } \\
\text { Concentration } \\
\text { in Final Test } \\
\text { Solutions } \\
(\mathrm{g} / \mathrm{L})\end{array}$ & $\begin{array}{c}\text { Geometric Mean } \\
\text { of NaCl } \\
\text { Concentrations } \\
(\mathrm{g} / \mathrm{L})\end{array}$ \\
\hline 0.25 & 0.210 & 0.210 & 0.215 & 0.212 \\
\hline 0.50 & 0.450 & 0.430 & 0.445 & 0.441 \\
\hline 1.0 & 0.865 & 0.835 & 0.842 & 0.847 \\
\hline 1.5 & 1.30 & 1.29 & 1.30 & 1.29 \\
\hline 2.0 & 1.75 & 1.74 & 1.69 & 1.73 \\
\hline 2.5 & 2.19 & 2.14 & 2.13 & 2.15 \\
\hline
\end{tabular}




\section{3-BROOD CHRONIC TOXICITY TEST WITH CERIODAPHNIA Survival and Reproduction Data}

Toxicant: $\quad$ sodium chloride

Test Initiation Date: $\quad$ 7/25/1997

\begin{tabular}{|c|c|c|c|c|c|}
\hline \multicolumn{6}{|c|}{ Reproduction at the contol concentration } \\
\hline Rep. & Day $3 / 4$ & Day 5 & Day 6 & Day 7 & Total \\
\hline 1 & 0 & 4 & 9 & 14 & 27 \\
\hline 2 & 0 & 4 & 8 & 10 & 22 \\
\hline 3 & 4 & 9. & 0 & 12 & 25 \\
\hline 4 & 0 & 4 & 7 & 11 & 22 \\
\hline 5 & 0 & 5 & 8 & 11 & 24 \\
\hline 6 & 0 & 4 & 9 & 11 & 24 \\
\hline 7 & 0 & 5 & 8 & 12 & 25 \\
\hline 8 & 0 & 5 & 9 & 12 & 26 \\
\hline 9 & 0 & 6 & 9 & 12 & 27 \\
\hline 10 & 4 & 6 & 1 & 7 & 18 \\
\hline 11 & 4 & 4 & 8 & 10 & 26 \\
\hline 12 & 0 & 4 & 7 & 12 & 23 \\
\hline 13 & 0 & 6) & 9 & 13 & 28 \\
\hline 14 & 0 & 4 & 9 & 5 & 18 \\
\hline 15 & 0 & 5 & 8 & 12 & 25 \\
\hline 16 & 0 & 4 & 5 & 10 & 19 \\
\hline 17 & 0 & 4 & 8 & 11 & 23 \\
\hline 18 & $\mathbf{0}$ & 5 & 7 & 10 & 22 \\
\hline 19 & 0 & 4 & 8 & 13 & 25 \\
\hline 20 & 0 & 4) & 8 & 10 & 22 \\
\hline \multicolumn{5}{|c|}{ Mean number of young } & 23.55 \\
\hline
\end{tabular}

\begin{tabular}{|c|c|c|c|c|c|}
\hline \multicolumn{6}{|c|}{ Reproduction at the $0.21 \mathrm{~g} / \mathrm{L}$ concentration } \\
\hline Rep. & Day 3/4 & Day 5 & Day 6 & Day 7 & Total \\
\hline 1] & 5 & 0 & 5 & 11 & 21 \\
\hline 2 & 4 & 0 & 11 & 12 & 27 \\
\hline 3 & 5 & 0 & 8 & 9 & 22 \\
\hline 4 & 4 & 0 & 10 & 13 & 27 \\
\hline 5 & 4 & 7 & 0 & 13 & 24 \\
\hline 6 & 3 & $\mathbf{0}$ & 11 & 0 & 14 \\
\hline 7 & 5 & $\mathbf{0}$ & 11 & 10 & 26 \\
\hline 8 & 4 & 8 & 0 & 11 & 23 \\
\hline 9 & 3 & $\mathbf{0}$ & 7 & 12 & 22 \\
\hline 10 & 4 & 10 & 0 & 11 & 25 \\
\hline 11 & 5 & 0 & 12 & 12 & 29 \\
\hline 12 & 4 & 0 & 6 & 11 & 21 \\
\hline 13 & 4) & 0 & 11 & 0 & 15 \\
\hline 14 & 4 & 5 & 0 & 12 & 21 \\
\hline 15 & 4 & 7 & 0 & 12 & 23 \\
\hline 16 & 4 & 0 & 6 & 11 & 21 \\
\hline 17 & 4 & 0 & 7 & 9 & 20 \\
\hline 18 & 1 & 5 & 6 & 11 & 23 \\
\hline 19 & 4 & 0 & 11 & 0 & 15 \\
\hline 20 & 4 & 0 & 5 & 11 & 20 \\
\hline \multicolumn{5}{|c|}{ Mean number of young per female } & 21.95 \\
\hline
\end{tabular}

\begin{tabular}{|c|c|c|c|c|c|}
\hline \multicolumn{6}{|c|}{ Reproduction at the $0.44 \mathrm{~g} / \mathrm{L}$ concentration } \\
\hline Rep. & Day 3/4 & Day 5 & Day 6 & Day 7 & Total \\
\hline 1 & 4 & of & 7 & 12 & 23 \\
\hline 2 & 3 & 0 & 8 & 9 & 20 \\
\hline 3 & 4 & 6 & 0 & 13 & 23 \\
\hline 4 & 0 & 5 & 8 & 13 & 26 \\
\hline 5 & 4 & 0 & 6 & 13. & 23 \\
\hline 6 & 5 & 0 & 9 & 13 & 27 \\
\hline 7 & o & 5 & 8 & 0 & 13 \\
\hline 8 & 3 & 8 & 0 & 13 & 24 \\
\hline 9 & 4 & 0 & 9 & 13 & 26 \\
\hline 10 & 3 & 0 & 7 & 13 & 23 \\
\hline 11 & 4 & 0 & 5 & 8 & 17 \\
\hline 12 & 3 & 0 & 7 & 6 & 16 \\
\hline 13 & 4 & 4 & 6 & 0 & 14 \\
\hline 14 & 4 & o) & 8 & 9 & 21 \\
\hline 15. & 4 & 7 & 0 & 13 & 24 \\
\hline 16 & 4 & 7 & 0 & 13 & 24 \\
\hline 17 & 5 & 0 & 8 & 12 & 25 \\
\hline 18 & 5) & 0 & 7 & 12 & 24 \\
\hline 19 & 4 & 0 & 7 & 12 & 23 \\
\hline 20 & 4 & 0 & 7 & 9 & 20 \\
\hline \multicolumn{5}{|c|}{ Mean number of young per female } & 21.8 \\
\hline
\end{tabular}

\begin{tabular}{|c|c|c|c|c|c|}
\hline \multicolumn{6}{|c|}{ Reproduction at the $0.85 \mathrm{~g} / \mathrm{L}$ concentration } \\
\hline Rep. & Day 3/4 & Day 5 & Day 6 & Day 7 & Total \\
\hline 1 & 4) & 0 & 7 & 11 & 22 \\
\hline 2 & 3 & 0 & 5 & 8 & 16 \\
\hline 3 & 0 & 4 & 6 & 1 & 11 \\
\hline 4 & 0 & 3 & 8 & 0 & 11 \\
\hline 5 & 4 & o) & 7 & 12 & 23 \\
\hline 6 & 3 & 0 & 8 & 10 & 21 \\
\hline 7 & 0 & 4 & 6 & 0 & 10 \\
\hline 8 & 4 & 0 & 6 & 5 & 15 \\
\hline 9 & 2 & 2 & 6 & 이 & 10 \\
\hline 10 & 3 & of & 6 & 0 & 9 \\
\hline 11 & o & 4) & 8 & 0 & 12 \\
\hline 12 & 이 & s) & 6 & 0 & 11 \\
\hline 13 & 3 & of & 7 & 10 & 20 \\
\hline 14) & 2 & 0) & 7 & 8 & 17 \\
\hline 15) & 3 & 0 & 7. & 9) & 19 \\
\hline 16 & 3 & 0 & 8 & 9 & 20 \\
\hline 17. & 2 & 0 & 8 & 0 & 10 \\
\hline 18 & o) & 5) & 5 & 0 & 10 \\
\hline 19 & 2 & 0 & 7 & 9 & 18 \\
\hline 20 & 0 & 4 & 7 & 0 & 11 \\
\hline \multicolumn{5}{|c|}{ Mean number of young per female } & 14.8 \\
\hline
\end{tabular}

$X$ denotes death of test organism 


\section{3-BROOD CHRONIC TOXICITY TEST WITH CERIODAPHNIA \\ Survival and Reproduction Data}

Toxicant: sodium chloride

Test Initiation Date: $\quad 7 / 25 / 1997$

\begin{tabular}{|c|c|c|c|c|c|}
\hline \multicolumn{6}{|c|}{ Reproduction at the $1.3 \mathrm{~g} / \mathrm{L}$ concentration } \\
\hline Rep. & Day $3 / 4$ & Day 5 & Day 6 & Day 7 & Total \\
\hline 1 & 3 & 0 & 0 & 10 & 13 \\
\hline 2 & 2 & 0 & 0 & 10 & 12 \\
\hline 3 & 2 & 0 & 0 & 8 & 10 \\
\hline 4 & 2 & 0 & 0 & 8 & 10 \\
\hline 5 & o] & 2 & $\mathrm{x}$ & $\mathrm{x}$ & 2 \\
\hline 6 & o) & 3 & 0 & 0 & 3 \\
\hline 7 & 3 & 0 & 7 & 7 & 17 \\
\hline 8 & 3 & 0 & 0 & 7 & 10 \\
\hline 9 & 4 & 0 & 0 & 7 & 11 \\
\hline 10 & 4 & 0 & 8 & 9 & 21 \\
\hline 11 & 1 & 0 & 4 & 8 & 13 \\
\hline 12 & 3 & 0 & 4 & 9 & 16 \\
\hline 13 & 3 & 0 & 4 & 9) & 16 \\
\hline 14 & o) & 2 & 4 & 11 & 17 \\
\hline 15 & 0 & 4 & 4 & 10 & 18 \\
\hline 16 & 3) & 0 & 1 & 11 & 15 \\
\hline 17 & 3) & 4 & 0 & 6 & 13 \\
\hline 18 & 2] & 0 & 6 & 9 & 17 \\
\hline 19 & 2 & 0 & 2 & 9] & 13 \\
\hline 20 & 0 & 3 & 6 & 0 & 9 \\
\hline \multicolumn{5}{|c|}{ Mean number of young per female } & 12.8 \\
\hline
\end{tabular}

\begin{tabular}{|c|c|c|c|c|c|}
\hline \multicolumn{6}{|c|}{ Reproduction at the $1.7 \mathrm{~g} / \mathrm{L}$ concentration } \\
\hline Rep. & Day $3 / 4$ & Day 5 & Day 6 & Day 7 & Total \\
\hline 1 & 0 & 0 & 0 & & 0 \\
\hline 2 & 0 & 0 & 0 & & 0 \\
\hline 3 & 0 & 0 & 2 & & 2 \\
\hline 4 & 0 & 0 & 2 & & 2 \\
\hline 5 & 0 & 0 & 0 & & 0 \\
\hline 6 & 0 & 0 & 2 & & 2 \\
\hline 7 & 0 & 0 & 2 & & 2 \\
\hline 8 & 0 & 0 & 2 & & 2 \\
\hline 9 & 0 & 0 & 0 & & 0 \\
\hline 10 & 0 & 0 & 0 & & 0 \\
\hline 11 & 0 & 0 & 0 & & 0 \\
\hline 12 & 0 & 0 & 0 & & 0 \\
\hline 13 & 0 & 0 & 0 & & 0 \\
\hline 14 & 0 & 0 & $\mathrm{x}$ & $\mathrm{X}$ & 0 \\
\hline 15 & $x$ & $\mathrm{x}$ & $x$ & $\mathrm{x}$ & 0 \\
\hline 16 & $x$ & $\mathrm{x}$ & $x$ & $\mathrm{x}$ & 0 \\
\hline 17 & 0 & 0 & 0 & & 0 \\
\hline 18 & 0 & 0 & 0 & & 0 \\
\hline 19 & 0 & 0 & 0 & & 0 \\
\hline 20 & 0 & 0 & 0 & & 0 \\
\hline \multicolumn{5}{|c|}{ Mean number of young per female } & 0.5 \\
\hline
\end{tabular}

\begin{tabular}{|c|c|c|c|c|c|}
\hline \multicolumn{6}{|c|}{ Reproduction at the $2.2 \mathrm{~g} / \mathrm{L}$ concentration } \\
\hline Rep. & Day $3 / 4$ & Day 5 & Day 6 & Day 7 & Total \\
\hline 1 & $\mathbf{x}$ & $\mathrm{x}$ & $\mathrm{x}$ & $\mathrm{x}$ & 0 \\
\hline 2 & $\mathbf{x}$ & $\mathrm{x}$ & $\mathrm{x}$ & $\mathrm{x}$ & 0 \\
\hline 3 & $\mathrm{x}$ & $\mathrm{x}$ & $\mathrm{x}$ & $\mathrm{x}$ & 0 \\
\hline 4 & $\mathrm{x}$ & $\mathrm{x}$ & $\mathrm{x}$ & $\mathrm{x}$ & 0 \\
\hline 5 & $\mathrm{x}$ & $\mathrm{x}$ & $\mathrm{x}$ & $\mathrm{X}$ & 0 \\
\hline 6 & $\mathrm{X}$ & $\mathrm{x}$ & $\mathrm{x}$ & $\mathrm{X}$ & 0 \\
\hline 7 & $\mathrm{X}$ & $\mathrm{x}$ & $\mathrm{X}$ & $\mathrm{X}$ & 0 \\
\hline 8 & $\mathrm{x}$ & $x$ & $\mathrm{x}$ & $\mathrm{x}$ & 0 \\
\hline 9 & $x$ & $\mathrm{x}$ & $\mathrm{x}$ & $\mathrm{x}$ & 0 \\
\hline 10 & $\mathrm{x}$ & $\mathrm{x}$ & $\mathrm{X}$ & $X$ & 0 \\
\hline 11 & $\mathrm{x}$ & $\mathrm{x}$ & $\mathrm{x}$ & $\mathrm{X}$ & 0 \\
\hline 12 & $\mathrm{x}$ & $\mathrm{X}$ & $\mathrm{x}$ & $x$ & 0 \\
\hline 13 & $\mathrm{x}$ & $\mathrm{X}$ & $x$ & $\mathbf{X}$ & 0 \\
\hline 14 & $\mathrm{x}$ & $x$ & $x$ & $\mathbf{X}$ & 0 \\
\hline 15 & $\mathrm{X}$ & $\mathrm{x}$ & $x$ & $x$ & 0 \\
\hline 16 & $\mathrm{x}$ & $\mathrm{X}$ & $x$ & $X$ & 0 \\
\hline 17 & $\mathrm{x}$ & $\mathrm{X}$ & $\mathrm{x}$ & $\mathrm{X}$ & 0 \\
\hline 18 & $\mathrm{x}$ & $\mathrm{x}$ & $x$ & $\mathrm{x}$ & 0 \\
\hline 19 & $\mathrm{x}$ & $\mathrm{X}$ & $x$ & $X$ & 0 \\
\hline 20 & $\mathrm{x}$ & $\mathrm{x}$ & $\mathrm{X}$ & $x$ & 0 \\
\hline Mean numb & er of young & er female & & & 0 \\
\hline
\end{tabular}

\section{$X$ denotes death of test organism}




\section{APPENDIX 2 A}

Summary of statistical data from the chronic $C$. dubia test with sodium chloride

\begin{tabular}{|c|c|c|c|c|c|c|c|c|}
\hline \multirow{2}{*}{ Group } & \multirow{2}{*}{ Identification } & \multirow{2}{*}{$\mathbf{N}$} & \multicolumn{6}{|c|}{ Reproduction } \\
\hline & & & Min & Max & Mean & Variance & SD & CV \% \\
\hline 1 & Control & 20 & 18 & 28 & 23.55 & 8.261 & 2.874 & 12.20 \\
\hline 2 & $0.21 \mathrm{ppt}$ & 20 & 14 & 29 & 21.95 & 16.050 & 4.006 & 18.25 \\
\hline 3 & $0.44 \mathrm{ppt}$ & 20 & 13 & 27 & 21.80 & 15.853 & 3.982 & 18.26 \\
\hline 4 & $0.85 \mathrm{ppt}$ & 20 & 9 & 23 & 14.80 & 23.011 & 4.797 & 32.41 \\
\hline 5 & $1.3 \mathrm{ppt}$ & 20 & 2 & 21 & 12.80 & 22.484 & 4.742 & 37.04 \\
\hline 6 & $1.7 \mathrm{ppt}$ & 20 & 0 & 2 & 0.50 & 0.789 & 0.889 & 177.70 \\
\hline 7 & $2.2 \mathrm{ppt}$ & 20 & \multicolumn{6}{|c|}{ no reproduction due to mortality of all test organisms } \\
\hline
\end{tabular}




\section{APPENDIX 2 A}

Summary of statistical analyses performed on data from the chronic $C$. dubia test with sodium chloride.

\section{SUMMARY OF FISHER'S EXACT TESTS ON MORTALITY DATA}

\begin{tabular}{clccc}
\hline Group & Identification & $\begin{array}{c}\text { Number } \\
\text { Exposed }\end{array}$ & $\begin{array}{c}\text { Number } \\
\text { Dead }\end{array}$ & $\begin{array}{c}\text { Sigificant } \\
(\mathrm{p}=0.05)\end{array}$ \\
\hline 1 & Control & 20 & 0 & \\
2 & $0.21 \mathrm{ppt}$ & 20 & 0 & \\
3 & $0.44 \mathrm{ppt}$ & 20 & 0 & \\
4 & $0.85 \mathrm{ppt}$ & 20 & 0 & \\
5 & $1.3 \mathrm{ppt}$ & 20 & 1 & $*$ \\
6 & $1.7 \mathrm{ppt}$ & 20 & 3 & \\
7 & $2.2 \mathrm{ppt}$ & 20 & 20 & \\
\hline
\end{tabular}




\section{APPENDIX 2 A}

Summary of statistical analyses performed on data from the chronic $C$. dubia test with sodium chloride.

CHI-SQUARE TEST FOR NORMALITY: ACTUAL AND EXPECTED FREQUENCIES

\begin{tabular}{llllll}
\hline INTERVAL & $<-1.5$ & -1.5 to $<-0.5$ & -0.5 to 0.5 & $>0.5$ to 1.5 & $>1.5$ \\
\hline EXPECTED & 8.040 & 29.040 & 45.840 & 29.040 & 8.040 \\
OBSERVED & 10 & 35 & 33 & 32 & 10 \\
\hline
\end{tabular}

Calculated Chi-Square goodness of fit test statistic $=\quad 6.0771$

Table Chi-Square value $($ alpha $=0.01)=13.277$

Data PASS normality test. Continue analysis.

\section{BARTLETT'S TEST FOR HOMOGENEITY OF VARIANCE}

Calculated B1 statistic $=\quad 43.64$

Table Chi-square, value $=15.09($ alpha $=0.01, \mathrm{df}=5)$

Table Chi-square value $=11.07$ (alpha $=0.05, \mathrm{df}=5$ )

Data FAIL B1 homogeneity test at 0.01 level. Try another transformation.

\begin{tabular}{ccccccc} 
STEEL'S MANY-ONE RANK TEST & - & Ho:Control<Treatment & \\
\hline Group & Identification & Mean & $\begin{array}{c}\text { Rank } \\
\text { Sum }\end{array}$ & $\begin{array}{c}\text { Critical } \\
\text { Value }\end{array}$ & df & Significant \\
\hline 1 & Control & 23.55 & & & 20 & \\
2 & $0.21 \mathrm{ppt}$ & 21.95 & 357.00 & 327.00 & 20 & \\
3 & $0.44 \mathrm{ppt}$ & 21.80 & 362.00 & 327.00 & 20 & \\
4 & $0.85 \mathrm{ppt}$ & 14.80 & 235.50 & 327.00 & 20 & $*$ \\
5 & $1.3 \mathrm{ppt}$ & 12.80 & 214.00 & 327.00 & 20 & $*$ \\
6 & $1.7 \mathrm{ppt}$ & 0.50 & 210.00 & 327.00 & 20 & $*$ \\
\hline
\end{tabular}

Critical values use $k=5$, are 1 talled, and alpha $=0.05$ 
Summary of water quality parameters measured on daily renewal solutions for the $C$. dubia sodium chloride chronic test. Values are expressed as means, ranges are presented in parentheses, $N=7$.

\begin{tabular}{|c|c|c|c|c|c|c|}
\hline $\begin{array}{c}\text { Concentration } \\
(\mathrm{\mu g} / \mathrm{L})\end{array}$ & $\begin{array}{c}\text { Dissolved } \\
\text { Oxygen } \\
(\mathrm{mg} / \mathrm{L})\end{array}$ & $\mathrm{pH}$ & $\begin{array}{c}\text { Temperature } \\
\left({ }^{\circ} \mathrm{C}\right)\end{array}$ & $\begin{array}{c}\text { Conductivity } \\
(\mathrm{ms} / \mathrm{cm})\end{array}$ & $\begin{array}{c}\text { Hardness } \\
(\mathrm{mg} / \mathrm{L} \text { as CaCO})\end{array}$ & $\begin{array}{c}\text { Allkalinity } \\
\left(\mathrm{mg} / \mathrm{L} \text { as } \mathrm{CaCO}_{3}\right)\end{array}$ \\
\hline Control & $\begin{array}{c}8.38 \\
(7.68-8.69)\end{array}$ & $\begin{array}{c}8.22 \\
(8.12-8.30)\end{array}$ & $\begin{array}{c}24.6 \\
(24.1-25.6)\end{array}$ & $\begin{array}{c}0.255 \\
(0.252-0.258)\end{array}$ & $\begin{array}{c}57 \\
(54-60)\end{array}$ & $\begin{array}{c}65 \\
(58-76)\end{array}$ \\
\hline 19 & $\begin{array}{c}8.30 \\
(7.96-8.79)\end{array}$ & $\begin{array}{c}8.17 \\
(8.05-8.32)\end{array}$ & $\begin{array}{c}24.5 \\
(24.2-24.7)\end{array}$ & $\begin{array}{c}0.736 \\
(0.723-0.749)\end{array}$ & & \\
\hline 27 & $\begin{array}{c}8.26 \\
(8.06-8.39)\end{array}$ & $\begin{array}{c}8.15 \\
(8.07-8.20)\end{array}$ & $\begin{array}{c}24.5 \\
(24.1-24.9)\end{array}$ & $\begin{array}{c}1.199 \\
(1.118-1.214)\end{array}$ & & \\
\hline 33 & $\begin{array}{c}8.24 \\
(7.78-8.56)\end{array}$ & $\begin{array}{c}8.16 \\
(8.05-8.25)\end{array}$ & $\begin{array}{c}24.6 \\
(24.1-25.2)\end{array}$ & $\begin{array}{c}2.169 \\
(2.150-2.190)\end{array}$ & & \\
\hline 39 & $\begin{array}{c}8.30 \\
(7.74-8.59)\end{array}$ & $\begin{array}{c}8.14 \\
(8.08-8.24)\end{array}$ & $\begin{array}{c}24.5 \\
(24.1-24.9)\end{array}$ & $\begin{array}{c}3.103 \\
(3.040-3.150)\end{array}$ & & \\
\hline 49 & $\begin{array}{c}8.40 \\
(7.99-8.79)\end{array}$ & $\begin{array}{c}8.12 \\
(8.04-8.25)\end{array}$ & $\begin{array}{c}24.5 \\
(24.1-25.1)\end{array}$ & $\begin{array}{c}3.863 \\
(3.520-3.960)\end{array}$ & & \\
\hline 53 & $\begin{array}{c}8.44 \\
(7.74-9.27)\end{array}$ & $\begin{array}{c}8.13 \\
(7.98-8.26)\end{array}$ & $\begin{array}{c}24.6 \\
(24.1-25.6)\end{array}$ & $\begin{array}{c}4.764 \\
(4.630-4.870)\end{array}$ & $\begin{array}{c}58 \\
(54-62)\end{array}$ & \\
\hline & & & & & 69 \\
& & & & \\
\hline
\end{tabular}

Summary of water quality parameters measured on 24-hour old solutions for the $C$. dubia sodium chloride chronic test. Values are expressed as means, ranges are presented in parentheses, $N=7$.

\begin{tabular}{|c|c|c|c|}
\hline $\begin{array}{c}\text { Concentration } \\
(\mu \mathrm{g} / \mathrm{L})\end{array}$ & $\begin{array}{c}\text { Dissolved } \\
\text { Oxygen } \\
(\mathrm{mg} / \mathrm{L})\end{array}$ & $\mathrm{pH}$ & $\begin{array}{c}\text { Temperature } \\
(\cdot \mathrm{C})\end{array}$ \\
\hline Control & $\begin{array}{c}7.83 \\
(7.76-7.90)\end{array}$ & $\begin{array}{c}8.27 \\
(8.17-8.33)\end{array}$ & $\begin{array}{c}24.9 \\
(24.6-25.1)\end{array}$ \\
\hline 19 & $\begin{array}{c}7.83 \\
(7.64-7.99)\end{array}$ & $\begin{array}{c}8.27 \\
(8.19-8.35)\end{array}$ & $\begin{array}{c}24.6 \\
(24.1-25.1)\end{array}$ \\
\hline 27 & $\begin{array}{c}8.01 \\
(7.82-8.28)\end{array}$ & $\begin{array}{c}8.26 \\
(8.17-8.37)\end{array}$ & $\begin{array}{c}24.7 \\
(24.3-25.1)\end{array}$ \\
\hline 33 & $\begin{array}{c}7.87 \\
(7.45-8.23)\end{array}$ & $\begin{array}{c}8.23 \\
(8.14-8.30)\end{array}$ & $\begin{array}{c}24.6 \\
(24.2-24.9)\end{array}$ \\
\hline 39 & $\begin{array}{c}8.00 \\
(7.73-8.26)\end{array}$ & $\begin{array}{c}8.21 \\
(8.12-8.28)\end{array}$ & $\begin{array}{c}24.4 \\
(24.1-24.7)\end{array}$ \\
\hline 49 & $\begin{array}{c}7.94 \\
(7.59-8.32)\end{array}$ & $\begin{array}{c}8.18 \\
(8.03-8.27)\end{array}$ & $\begin{array}{c}24.6 \\
(24.2-25.2) .\end{array}$ \\
\hline 53 & $\begin{array}{c}7.86 \\
(7.43-8.21)\end{array}$ & $\begin{array}{c}8.16 \\
(7.98-8.24)\end{array}$ & $\begin{array}{c}24.7 \\
(24.1-25.3)\end{array}$ \\
\hline
\end{tabular}


APPENDIX 2 B

CHRONIC TOXICITY TEST DATA:

D. ambigua EXPOSED TO SODIUM CHLORIDE 


\section{APPENDIX 2 - ANALYTICAL CHEMISTRY DATA - SODIUM CHLORIDE}

Nominal and actual concentrations of sodium chloride in solutions used for chronic toxicity testing. Actual concentrations of sodium were measured on three samples taken during the chronic test period. Values were determined by Trace Scan ICP.

\begin{tabular}{|c|c|c|c|c|}
\hline $\begin{array}{l}\text { Sample } \\
\text { Time }\end{array}$ & $\begin{array}{l}\text { Nominal NaCl } \\
\text { Concentration } \\
(\mathrm{g} / \mathrm{L})\end{array}$ & $\begin{array}{c}\text { Measured Na } \\
\text { Concentration } \\
(\mathrm{g} / \mathrm{L})\end{array}$ & $\begin{array}{l}\text { Measured Na } \\
\text { minus } \\
\text { Background Na } \\
\text { Concentration } 1 \\
(\mathrm{~g} / \mathrm{L})\end{array}$ & $\begin{array}{c}\text { Actual NaCI } \\
\text { Concentration } \\
(\mathrm{g} / \mathrm{L})\end{array}$ \\
\hline \multirow[t]{6}{*}{ Initial } & 0.25 & 0.108 & 0.0826 & 0.210 \\
\hline & 0.5 & 0.202 & 0.1766 & 0.450 \\
\hline & 1.0 & 0.365 & 0.3396 & 0.865 \\
\hline & 1.5 & 0.536 & 0.5106 & 1.30 \\
\hline & 2.0 & 0.714 & 0.6886 & 1.75 \\
\hline & 2.5 & 0.885 & 0.8596 & 2.19 \\
\hline \multirow[t]{6}{*}{ Mid-point } & 0.25 & 0.108 & 0.0826 & 0.210 \\
\hline & 0.5 & 0.194 & 0.1686 & 0.430 \\
\hline & 1.0 & 0.353 & 0.3276 & 0.835 \\
\hline & 1.5 & 0.531 & 0.5056 & 1.29 \\
\hline & 2.0 & 0.710 & 0.6846 & 1.74 \\
\hline & 2.5 & 0.865 & 0.8396 & 2.14 \\
\hline \multirow[t]{6}{*}{ Final ${ }^{*}$} & 0.25 & 0.110 & 0.0846 & 0.215 \\
\hline & 0.5 & 0.200 & 0.1746 & 0.445 \\
\hline & 1.0 & 0.356 & 0.3306 & 0.842 \\
\hline & 1.5 & 0.535 & 0.5096 & 1.30 \\
\hline & 2.0 & 0.689 & 0.6636 & 1.69 \\
\hline & 2.5 & 0.862 & 0.8366 & 2.13 \\
\hline
\end{tabular}

${ }^{1}$ Background Na concentration $=0.0254 \mathrm{~g} / \mathrm{L}$.

${ }^{2}$ Concentration of $\mathrm{NaCl}$ was calculated using the following formula:

$[\mathrm{NaCl}]=([\mathrm{Na}] / 22.9) * 58.35$

Geometric Means of the sodium chloride concentrations.

\begin{tabular}{|c|c|c|c|c|}
\hline $\begin{array}{c}\text { Nominal NaC } \\
\text { Concentration } \\
(\mathrm{g} / \mathrm{L})\end{array}$ & $\begin{array}{c}\text { Measured NaCl } \\
\text { Concentration } \\
\text { in Initial Test } \\
\text { Solutions } \\
(\mathrm{g} / \mathrm{L})\end{array}$ & $\begin{array}{c}\text { Measured NaCl } \\
\text { Concentration in } \\
\text { Mid-way Point } \\
\text { Solutions } \\
(\mathrm{g} / \mathrm{L})\end{array}$ & $\begin{array}{c}\text { Measured NaCd } \\
\text { Concentration } \\
\text { in Final Test } \\
\text { Solutions } \\
(\mathrm{g} / \mathrm{L})\end{array}$ & $\begin{array}{c}\text { Geometric Mean } \\
\text { of NaCl } \\
\text { Concentrations } \\
(\mathrm{g} / \mathrm{L})\end{array}$ \\
\hline 0.25 & 0.210 & 0.210 & 0.215 & 0.212 \\
\hline 0.50 & 0.450 & 0.430 & 0.445 & 0.441 \\
\hline 1.0 & 0.865 & 0.835 & 0.842 & 0.847 \\
\hline 1.5 & 1.30 & 1.29 & 1.30 & 1.29 \\
\hline 2.0 & 1.75 & 1.74 & 1.69 & 1.73 \\
\hline 2.5 & 2.19 & 2.14 & 2.13 & 2.15 \\
\hline
\end{tabular}




\section{3-BROOD CHRONIC TOXICITY TEST WITH DAPHNIA AMBIGUA \\ Survival and Reproduction Data}

Toxicant: Sodium chloride

Test Initiation Date: $\mathbf{8 - 8 - 9 7}$

\begin{tabular}{|r|r|r|r|r|r|r|}
\hline Reproduction at the control concentration \\
\hline Rep. & Day 5/6 & Day 7 & Day 8 & Day 9 & Day 10 & Total \\
\hline 1 & 3 & 3 & 0 & 0 & 11 & 17 \\
\hline 2 & 4 & 11 & 0 & 0 & 5 & 20 \\
\hline 3 & 4 & 3 & 0 & 0 & 13 & 20 \\
\hline 4 & 4 & 0 & 0 & 0 & 6 & 10 \\
\hline 5 & 4 & 0 & 10 & 0 & 7 & 21 \\
\hline 6 & 0 & 0 & 15 & 0 & 12 & 27 \\
\hline 7 & 4 & 10 & $\times$ & $x$ & $x$ & 14 \\
\hline 8 & 6 & 0 & 4 & 0 & 7 & 17 \\
\hline 9 & 5 & 0 & 3 & 0 & 3 & 11 \\
\hline 10 & 4 & 0 & 0 & 0 & 10 & 14 \\
\hline 11 & 0 & 0 & 0 & 0 & 14 & 14 \\
\hline 12 & 0 & 0 & 6 & 0 & 10 & 16 \\
\hline 13 & 3 & 0 & 4 & 0 & 6 & 13 \\
\hline 14 & 3 & 0 & 4 & 0 & 6 & 13 \\
\hline 15 & 4 & 0 & 4 & 0 & 4 & 12 \\
\hline 16 & 5 & 0 & 6 & 0 & 0 & 11 \\
\hline 17 & 0 & 0 & 3 & 7 & 0 & 10 \\
\hline 18 & 5 & 0 & 0 & 0 & 12 & 17 \\
\hline 19 & 4 & 0 & 3 & 3 & 6 & 16 \\
\hline 20 & 4 & 4 & $\times$ & $x$ & $x$ & 8 \\
\hline Mean number of young per female & & & 15.05 \\
\hline
\end{tabular}

\begin{tabular}{|c|c|c|c|c|c|c|}
\hline \multicolumn{7}{|c|}{ Reproduction at the $0.21 \mathrm{~g} / \mathrm{L}$ concentration } \\
\hline Rep. & Day 5/6 & Day 7 & Day 8 & Day 9 & Day 10 & Total \\
\hline 1 & 4) & o) & 0] & 3) & 0 & 7 \\
\hline 2 & 4 & 0 & 4 & 0 & 0 & 8 \\
\hline 3 & 4 & 0 & 6) & 4 & 0 & 14 \\
\hline 4 & 4 & 0 & 8) & 10) & 15 & 37 \\
\hline 5 & 이 & 4 & $\mathrm{x}$ & $\mathrm{x}$ & $\mathrm{x}$ & 4 \\
\hline 6 & 4] & o) & o) & 0| & 0 & 4 \\
\hline 7 & 6) & 0 & 6) & 4) & $x$ & 16 \\
\hline 8 & 3 & of & 3 & 0 & 0 & 6 \\
\hline 9 & 5 & o & 9] & 0 & 6 & 20 \\
\hline 10 & s) & 5 & 이 & 0 & 0 & 10 \\
\hline 11 & 5) & of & of & 6) & 4 & 15 \\
\hline 12 & 0) & 6 & 0 & 0] & 4 & 10 \\
\hline 13 & 6 & 0 & 15 & of & 9 & 30 \\
\hline 14 & 4 & of & 0 & 17 & 0 & 21 \\
\hline 15 & 4 & 0 & 13 & 0] & 15 & 32 \\
\hline 16 & 6 & 0 & 14 & 12 & 0 & 32 \\
\hline 17 & 5) & 이 & 0) & 1 & 0 & 6 \\
\hline 18 & 6 & 4 & 0 & of & 4 & 14 \\
\hline 19 & 4 & o) & 0) & 2 & 0 & 6 \\
\hline 20 & 5 & o) & 5 & $\mathrm{x}$ & $x$ & 10 \\
\hline \multicolumn{6}{|c|}{ Mean number of young per female } & 15.1 \\
\hline
\end{tabular}

\begin{tabular}{|c|c|c|c|c|c|c|}
\hline \multicolumn{7}{|c|}{ Reproduction at the $0.44 \mathrm{~g} / \mathrm{L}$ concentration } \\
\hline Rep. & Day $\$ / 6$ & Day 7 & Day 8 & Day 9 & Day 10 & Total \\
\hline 1 & 3 & 0 & 9 & 0 & 5 & 17 \\
\hline 2 & 5 & 0 & 6 & 0 & 9 & 20 \\
\hline 3 & 3 & 0 & 0 & 0 & 8 & 11 \\
\hline 4 & 2 & 4 & 0 & 0 & 6 & 12 \\
\hline 5 & 이 & 4 & 0 & 7 & 4 & 15 \\
\hline 6 & 2 & 0 & 3 & 0 & 7 & 12 \\
\hline 7 & 3 & 0 & 0 & 4 & 6 & 13 \\
\hline 8 & 4 & 0 & 3 & 0 & 5 & 12 \\
\hline 9 & 0 & 5 & 0 & 0 & 4 & 9 \\
\hline 10 & 3 & 0 & 8 & 0 & 5 & 16 \\
\hline 11 & 4 & 0 & 7 & 0 & 4 & 15 \\
\hline 12 & 2 & 0 & 4 & 0 & 7 & 13 \\
\hline 13 & 4 & 0 & 4 & 0 & 5 & 13 \\
\hline 14 & 3 & 0 & 9 & 0 & 7 & 19 \\
\hline 15 & 3 & 0 & 2 & $\mathrm{x}$ & $x$ & 5 \\
\hline 16 & 2 & 0 & 3 & 0 & 6 & 11 \\
\hline 17 & 3 & 0 & 4 & 0 & 8 & 15 \\
\hline 18 & 3 & 0 & 3 & 0 & 5 & 11 \\
\hline 19 & 2 & 0 & 3 & 0 & 6 & 11 \\
\hline 20 & 3 & 0 & 0 & 4 & 5 & 12 \\
\hline \multicolumn{6}{|c|}{ Mean number of young per female } & 13.1 \\
\hline
\end{tabular}

\begin{tabular}{|c|c|c|c|c|c|c|}
\hline \multicolumn{7}{|c|}{ Reproduction at the $0.85 \mathrm{~g} / \mathrm{L}$ concentration } \\
\hline Rep. & Day $s / 6$ & Day 7 & Day 8 & Day 9 & Day 10 & Total \\
\hline 1 & $\mathrm{x}$ & $x$ & $\mathrm{x}$ & $\mathrm{x}$ & $\mathrm{x}$ & 0 \\
\hline 2 & $\mathrm{x}$ & $\mathrm{x}$ & $\mathrm{x}$ & $\mathrm{x}$ & $\mathrm{x}$ & 0 \\
\hline 3 & 2 & o) & 이 & o) & 3 & 5 \\
\hline 4 & 0 & 0 & 1 & 0 & $\mathrm{x}$ & 1 \\
\hline 5 & 0 & 0 & 0 & 0 & 2 & 2 \\
\hline 6 & 0 & 0] & o) & 0 & 이 & 0 \\
\hline 7 & 0 & 0 & 0 & 0 & $\mathrm{x}$ & 0 \\
\hline 8 & $\mathbf{x}$ & $\mathbf{x}$ & $\mathrm{x}$ & $\mathbf{x}$ & $\mathrm{x}$ & 0 \\
\hline 9 & 0 & 0) & 4) & 0 & 3 & 7 \\
\hline 10 & 0 & 0 & 0 & 0 & 5 & 5 \\
\hline 11 & $\mathrm{X}$ & $\mathrm{x}$ & $\mathrm{x}$ & $\mathrm{x}$ & $\mathrm{x}$ & 0 \\
\hline 12 & 0 & o) & 6) & o) & 6] & 12 \\
\hline 13 & 0 & 이 & 이 & 0 & 0 & 0 \\
\hline 14 & $x$ & $\mathrm{x}$ & $\mathrm{x}$ & $x$ & $\mathrm{x}$ & 0 \\
\hline 15 & 0 & o) & o) & 0 & 11 & 11 \\
\hline 16 & 2 & 0 & $\mathrm{x}$ & $\mathrm{x}$ & $\mathrm{x}$ & 2 \\
\hline 17 & 0 & 0 & 4 & of & 6 & 10 \\
\hline 18 & 0 & 0 & of & 0 & 0 & 0 \\
\hline 19 & $\mathrm{x}$ & $x$ & $\mathrm{x}$ & $\mathrm{x}$ & $\mathrm{x}$ & 0 \\
\hline 20 & 3 & of & 0 & 0 & 4 & 7 \\
\hline \multicolumn{6}{|c|}{ Mean number of young per female } & 3.1 \\
\hline
\end{tabular}

$X$ denotes death of test organism 


\section{3-BROOD CHRONIC TOXICITY TEST WITH DAPHNIA AMBIGUA \\ Survival and Reproduction Data}

Toxicant: Sodium chloride

Test Initiation Date: $8-8-97$

\begin{tabular}{|r|r|r|r|r|r|r|}
\hline \multicolumn{7}{|l|}{ Reproduction at the 1.3 g/L concentration } \\
\hline Rep. & Day 5/6 & Day 7 & Day 8 & Day 9 & Day 10 & Total \\
\hline 1 & $\mathrm{X}$ & $\mathrm{X}$ & $\mathrm{X}$ & $\mathrm{X}$ & $\mathrm{X}$ & 0 \\
\hline 2 & 0 & 0 & 0 & 2 & 0 & 2 \\
\hline 3 & 0 & 0 & 0 & 3 & 0 & 3 \\
\hline 4 & $\mathrm{X}$ & $\mathrm{X}$ & $\mathrm{X}$ & $\mathrm{X}$ & $\mathrm{X}$ & 0 \\
\hline 5 & 0 & 0 & 0 & 0 & 0 & 0 \\
\hline 6 & $\mathrm{X}$ & $\mathrm{X}$ & $\mathrm{X}$ & $\mathrm{X}$ & $\mathrm{X}$ & 0 \\
\hline 7 & 0 & 0 & 0 & 0 & 0 & 0 \\
\hline 8 & 0 & 0 & 0 & 0 & 0 & 0 \\
\hline 9 & $\mathrm{X}$ & $\mathrm{X}$ & $\mathrm{X}$ & $\mathrm{X}$ & $\mathrm{X}$ & 0 \\
\hline 10 & $\mathrm{X}$ & $\mathrm{X}$ & $\mathrm{X}$ & $\mathrm{X}$ & $\mathrm{X}$ & 0 \\
\hline 11 & $\mathrm{X}$ & $\mathrm{X}$ & $\mathrm{X}$ & $\mathrm{X}$ & $\mathrm{X}$ & 0 \\
\hline 12 & $\mathrm{X}$ & $\mathrm{X}$ & $\mathrm{X}$ & $\mathrm{X}$ & $\mathrm{X}$ & 0 \\
\hline 13 & $\mathrm{X}$ & $\mathrm{X}$ & $\mathrm{X}$ & $\mathrm{X}$ & $\mathrm{X}$ & 0 \\
\hline 14 & $\mathrm{X}$ & $\mathrm{X}$ & $\mathrm{X}$ & $\mathrm{X}$ & $\mathrm{X}$ & 0 \\
\hline 15 & $\mathrm{X}$ & $\mathrm{X}$ & $\mathrm{X}$ & $\mathrm{X}$ & $\mathrm{X}$ & 0 \\
\hline 16 & 0 & 0 & 0 & 0 & 0 & 0 \\
\hline 17 & $\mathrm{X}$ & $\mathrm{X}$ & $\mathrm{X}$ & $\mathrm{X}$ & $\mathrm{X}$ & 0 \\
\hline 18 & $\mathrm{X}$ & $\mathrm{X}$ & $\mathrm{X}$ & $\mathrm{X}$ & $\mathrm{X}$ & 0 \\
\hline 19 & $\mathrm{X}$ & $\mathrm{X}$ & $\mathrm{X}$ & $\mathrm{X}$ & $\mathrm{X}$ & 0 \\
\hline 20 & $\mathrm{X}$ & $\mathrm{X}$ & $\mathrm{X}$ & $\mathrm{X}$ & $\mathrm{X}$ & 0 \\
\hline Mean number of young per female & & & 0.25 \\
\hline
\end{tabular}

\begin{tabular}{|r|r|r|r|r|r|r|}
\hline \multicolumn{7}{|l|}{ Reproduction at the 2.2 g/L concentration } \\
\hline Rep. & Day 5/6 & Day 7 & Day 8 & Day 9 & Day 10 & Total \\
\hline 1 & $\mathrm{X}$ & $\mathrm{X}$ & $\mathrm{X}$ & $\mathrm{X}$ & $\mathrm{X}$ & 0 \\
\hline 2 & $\mathrm{X}$ & $\mathrm{X}$ & $\mathrm{X}$ & $\mathrm{X}$ & $\mathrm{X}$ & 0 \\
\hline 3 & $\mathrm{X}$ & $\mathrm{X}$ & $\mathrm{X}$ & $\mathrm{X}$ & $\mathrm{X}$ & 0 \\
\hline 4 & $\mathrm{X}$ & $\mathrm{X}$ & $\mathrm{X}$ & $\mathrm{X}$ & $\mathrm{X}$ & 0 \\
\hline 5 & $\mathrm{X}$ & $\mathrm{X}$ & $\mathrm{X}$ & $\mathrm{X}$ & $\mathrm{X}$ & 0 \\
\hline 6 & $\mathrm{X}$ & $\mathrm{X}$ & $\mathrm{X}$ & $\mathrm{X}$ & $\mathrm{X}$ & 0 \\
\hline 7 & $\mathrm{X}$ & $\mathrm{X}$ & $\mathrm{X}$ & $\mathrm{X}$ & $\mathrm{X}$ & 0 \\
\hline 8 & $\mathrm{X}$ & $\mathrm{X}$ & $\mathrm{X}$ & $\mathrm{X}$ & $\mathrm{X}$ & 0 \\
\hline 9 & $\mathrm{X}$ & $\mathrm{X}$ & $\mathrm{X}$ & $\mathrm{X}$ & $\mathrm{X}$ & 0 \\
\hline 10 & $\mathrm{X}$ & $\mathrm{X}$ & $\mathrm{X}$ & $\mathrm{X}$ & $\mathrm{X}$ & 0 \\
\hline 11 & $\mathrm{X}$ & $\mathrm{X}$ & $\mathrm{X}$ & $\mathrm{X}$ & $\mathrm{X}$ & 0 \\
\hline 12 & $\mathrm{X}$ & $\mathrm{X}$ & $\mathrm{X}$ & $\mathrm{X}$ & $\mathrm{X}$ & 0 \\
\hline 13 & $\mathrm{X}$ & $\mathrm{X}$ & $\mathrm{X}$ & $\mathrm{X}$ & $\mathrm{X}$ & 0 \\
\hline 14 & $\mathrm{X}$ & $\mathrm{X}$ & $\mathrm{X}$ & $\mathrm{X}$ & $\mathrm{X}$ & 0 \\
\hline 15 & $\mathrm{X}$ & $\mathrm{X}$ & $\mathrm{X}$ & $\mathrm{X}$ & $\mathrm{X}$ & 0 \\
\hline 16 & $\mathrm{X}$ & $\mathrm{X}$ & $\mathrm{X}$ & $\mathrm{X}$ & $\mathrm{X}$ & 0 \\
\hline 17 & $\mathrm{X}$ & $\mathrm{X}$ & $\mathrm{X}$ & $\mathrm{X}$ & $\mathrm{X}$ & 0 \\
\hline 18 & $\mathrm{X}$ & $\mathrm{X}$ & $\mathrm{X}$ & $\mathrm{X}$ & $\mathrm{X}$ & 0 \\
\hline 19 & $\mathrm{X}$ & $\mathrm{X}$ & $\mathrm{X}$ & $\mathrm{X}$ & $\mathrm{X}$ & 0 \\
\hline 20 & $\mathrm{X}$ & $\mathrm{X}$ & $\mathrm{X}$ & $\mathrm{X}$ & $\mathrm{X}$ & 0 \\
\hline Mean number of young per female & & & 0 \\
\hline
\end{tabular}

$X$ denotes death of test organism

\begin{tabular}{|r|r|r|r|r|r|r|}
\hline \multicolumn{7}{|r|}{ Reproduction at the 1.7 g/L concentration } \\
\hline Rep. & Day 5/6 & Day 7 & Day 8 & Day 9 & Day 10 & Total \\
\hline 1 & $\mathrm{X}$ & $\mathrm{X}$ & $\mathrm{X}$ & $\mathrm{X}$ & $\mathrm{X}$ & 0 \\
\hline 2 & $\mathrm{X}$ & $\mathrm{X}$ & $\mathrm{X}$ & $\mathrm{X}$ & $\mathrm{X}$ & 0 \\
\hline 3 & $\mathrm{X}$ & $\mathrm{X}$ & $\mathrm{X}$ & $\mathrm{X}$ & $\mathrm{X}$ & 0 \\
\hline 4 & $\mathrm{X}$ & $\mathrm{X}$ & $\mathrm{X}$ & $\mathrm{X}$ & $\mathrm{X}$ & 0 \\
\hline $\mathrm{S}$ & $\mathrm{X}$ & $\mathrm{X}$ & $\mathrm{X}$ & $\mathrm{X}$ & $\mathrm{X}$ & 0 \\
\hline 6 & $\mathrm{X}$ & $\mathrm{X}$ & $\mathrm{X}$ & $\mathrm{X}$ & $\mathrm{X}$ & 0 \\
\hline 7 & $\mathrm{X}$ & $\mathrm{X}$ & $\mathrm{X}$ & $\mathrm{X}$ & $\mathrm{X}$ & 0 \\
\hline 8 & $\mathrm{X}$ & $\mathrm{X}$ & $\mathrm{X}$ & $\mathrm{X}$ & $\mathrm{X}$ & 0 \\
\hline 9 & $\mathrm{X}$ & $\mathrm{X}$ & $\mathrm{X}$ & $\mathrm{X}$ & $\mathrm{X}$ & 0 \\
\hline 10 & $\mathrm{X}$ & $\mathrm{X}$ & $\mathrm{X}$ & $\mathrm{X}$ & $\mathrm{X}$ & 0 \\
\hline 11 & $\mathrm{X}$ & $\mathrm{X}$ & $\mathrm{X}$ & $\mathrm{X}$ & $\mathrm{X}$ & 0 \\
\hline 12 & $\mathrm{X}$ & $\mathrm{X}$ & $\mathrm{X}$ & $\mathrm{X}$ & $\mathrm{X}$ & 0 \\
\hline 13 & $\mathrm{X}$ & $\mathrm{X}$ & $\mathrm{X}$ & $\mathrm{X}$ & $\mathrm{X}$ & 0 \\
\hline 14 & $\mathrm{X}$ & $\mathrm{X}$ & $\mathrm{X}$ & $\mathrm{X}$ & $\mathrm{X}$ & 0 \\
\hline 15 & $\mathrm{X}$ & $\mathrm{X}$ & $\mathrm{X}$ & $\mathrm{X}$ & $\mathrm{X}$ & 0 \\
\hline 16 & $\mathrm{X}$ & $\mathrm{X}$ & $\mathrm{X}$ & $\mathrm{X}$ & $\mathrm{X}$ & 0 \\
\hline 17 & $\mathrm{X}$ & $\mathrm{X}$ & $\mathrm{X}$ & $\mathrm{X}$ & $\mathrm{X}$ & 0 \\
\hline 18 & $\mathrm{X}$ & $\mathrm{X}$ & $\mathrm{X}$ & $\mathrm{X}$ & $\mathrm{X}$ & 0 \\
\hline 19 & $\mathrm{X}$ & $\mathrm{X}$ & $\mathrm{X}$ & $\mathrm{X}$ & $\mathrm{X}$ & 0 \\
\hline 20 & $\mathrm{X}$ & $\mathrm{X}$ & $\mathrm{X}$ & $\mathrm{X}$ & $\mathrm{X}$ & 0 \\
\hline Mean number of young per female & & & 0 \\
\hline \multicolumn{7}{|c|}{}
\end{tabular}


APPENDIX 2 B

Summary of statistical data from the chronic $D$. ambigua test with sodium chloride

\begin{tabular}{cccccccccc}
\hline \multirow{2}{*}{ Group } & Identification & $\mathrm{N}$ & \multicolumn{7}{c}{ Reproduction } \\
\cline { 5 - 9 } & & Control & 20 & 8 & 27 & 15.05 & 20.787 & 4.559 & 30.29 \\
1 & $0.21 \mathrm{ppt}$ & 20 & 4 & 37 & 15.10 & 106.516 & 10.321 & 68.35 \\
2 & $0.44 \mathrm{ppt}$ & 20 & 5 & 20 & 13.10 & 11.674 & 3.417 & 26.08 \\
3 & $0.85 \mathrm{ppt}$ & 20 & 0 & 12 & 3.10 & 17.358 & 4.166 & 134.4 \\
4 & $1.3 \mathrm{ppt}$ & 20 & 0 & 3 & 0.25 & 0.618 & 0.786 & 314.56 \\
5 & $1.7 \mathrm{ppt}$ & 20 & & no reproduction due to mortality of all test organisms & \\
6 & $2.2 \mathrm{ppt}$ & 20 & & no reproduction due to mortality of all test organisms \\
7 & & &
\end{tabular}




\section{APPENDIX 2 B}

Summary of statistical analyses performed on data from the chronic $D$. ambigua test with sodium chloride.

\section{SUMMARY OF FISHER'S EXACT TESTS ON MORTALITY DATA}

\begin{tabular}{clccc}
\hline Group & Identification & $\begin{array}{c}\text { Number } \\
\text { Exposed }\end{array}$ & $\begin{array}{c}\text { Number } \\
\text { Dead }\end{array}$ & $\begin{array}{c}\text { Sigificant } \\
(\mathrm{p}=0.05)\end{array}$ \\
\hline & Control & 20 & 2 & \\
1 & $0.21 \mathrm{ppt}$ & 20 & 2 & $*$ \\
2 & $0.44 \mathrm{ppt}$ & 20 & 1 & $*$ \\
3 & $0.85 \mathrm{ppt}$ & 20 & 10 & $*$ \\
4 & $1.3 \mathrm{ppt}$ & 20 & 14 & $*$ \\
5 & $1.7 \mathrm{ppt}$ & 20 & 20 & $*$ \\
6 & $2.2 \mathrm{ppt}$ & 20 & 20 & $*$ \\
\hline
\end{tabular}

Note: Those concentrations with significant mortality were dropped from further statistical analysis. 
APPENDIX 2 B

Summary of statistical analyses performed on data from the chronic $D$. ambigua test with sodium chloride.

CHI-SQUARE TEST FOR NORMALITY: ACTUAL AND EXPECTED FREQUENCIES

\begin{tabular}{llllll}
\hline INTERVAL & $<-1.5$ & -1.5 to $<-0.5$ & -0.5 to 0.5 & $>0.5$ to 1.5 & $>1.5$ \\
\hline EXPECTED & 4.020 & 14.520 & 22.920 & 14.520 & 4.020 \\
OBSERVED & 2 & 17 & 25 & 10 & 6 \\
\hline
\end{tabular}

Calculated Chi-Square goodness of fit test statistic $=4.0096$

Table Chi-Square value $($ alpha $=0.01)=13.277$

Data PASS normality test. Continue analysis.

\section{BARTLETT'S TEST FOR HOMOGENEITY OF VARIANCE}

Calculated B1 statistic $=25.01$

Table Chi-square value $=9.21($ alpha $=0.01, \mathrm{df}=2)$

Table Chi-square value $=5.99($ alpha $=0.05, \mathrm{df}=2)$

Data FAIL B1 homogeneity test at 0.01 level.

STEEL'S MANY-ONE RANK TEST - $\quad$ Ho:Control<Treatment

\begin{tabular}{ccccccc}
\hline Group & Identification & Mean & $\begin{array}{c}\text { Rank } \\
\text { Sum }\end{array}$ & $\begin{array}{c}\text { Critical } \\
\text { Value }\end{array}$ & df & Significant \\
\hline 1 & Control & 15.05 & & & 20 & \\
2 & $0.21 \mathrm{ppt}$ & 15.10 & 374.00 & 339.00 & 20 & \\
3 & $0.44 \mathrm{ppt}$ & 13.10 & 362.50 & 339.00 & 20 & \\
\hline
\end{tabular}

Critical values use $k=5$, are 1 tailed, and alpha $=0.05$ 
Summary of water quality parameters measured on daily renewal solutions for the $D$. ambigua sodium chloride chronic test. Values are expressed as means, ranges are presented in parentheses, $\mathrm{N}=10$.

\begin{tabular}{|c|c|c|c|c|c|c|}
\hline $\begin{array}{c}\text { Concentration } \\
(\mathrm{\mu g} / \mathrm{L})\end{array}$ & $\begin{array}{c}\text { Dissolved } \\
\text { Oxygen } \\
(\mathrm{mg} / \mathrm{L})\end{array}$ & $\mathrm{pH}$ & $\begin{array}{c}\text { Temperature } \\
(\cdot \mathrm{C})\end{array}$ & $\begin{array}{c}\text { Conductivity } \\
(\mathrm{ms} / \mathrm{cm})\end{array}$ & $\begin{array}{c}\text { Hardness } \\
\left(\mathrm{mg} / \mathrm{L} \text { as } \mathrm{CaCO}_{3}\right)\end{array}$ & $\begin{array}{c}\text { Alkalinity } \\
\left(\mathrm{mg} / \mathrm{L} \text { as } \mathrm{CaCO}_{3}\right)\end{array}$ \\
\hline Control & $\begin{array}{c}8.86 \\
(8.46-9.10)\end{array}$ & $\begin{array}{c}8.17 \\
(8.10-8.22)\end{array}$ & $\begin{array}{c}20.9 \\
(20.5-21.3)\end{array}$ & $\begin{array}{c}0.252 \\
(0.248-0.257)\end{array}$ & $\begin{array}{c}59 \\
(54-64)\end{array}$ & $\begin{array}{c}70 \\
(64-74)\end{array}$ \\
\hline 19 & $\begin{array}{c}8.86 \\
(8.54-9.11)\end{array}$ & $\begin{array}{c}8.17 \\
(8.05-8.23)\end{array}$ & $\begin{array}{c}21.1 \\
(20.8-21.5)\end{array}$ & $\begin{array}{c}0.738 \\
(0.734-0.741)\end{array}$ & & \\
\hline 27 & $\begin{array}{c}8.87 \\
(8.65-9.06)\end{array}$ & $\begin{array}{c}8.14 \\
(8.07-8.20)\end{array}$ & $\begin{array}{c}21.1 \\
(20.7-21.5)\end{array}$ & $\begin{array}{c}1.213 \\
(1.211-1.218)\end{array}$ & & \\
\hline 33 & $\begin{array}{c}8.78 \\
(8.39-9.10)\end{array}$ & $\begin{array}{c}8.16 \\
(8.02-8.21)\end{array}$ & $\begin{array}{c}21.2 \\
(20.8-21.7)\end{array}$ & $\begin{array}{c}2.186 \\
(2.160-2.220)\end{array}$ & & \\
\hline 39 & $\begin{array}{c}8.87 \\
(8.52-9.08)\end{array}$ & $\begin{array}{c}8.14 \\
(8.04-8.20)\end{array}$ & $\begin{array}{c}21.2 \\
(20.8-21.9)\end{array}$ & $\begin{array}{c}3.131 \\
(3.110-3.160)\end{array}$ & & \\
\hline 49 & $\begin{array}{c}8.91 \\
(8.61-9.10)\end{array}$ & $\begin{array}{c}8.11 \\
(7.98-8.19)\end{array}$ & $\begin{array}{c}21.0 \\
(20.5-21.6)\end{array}$ & $\begin{array}{c}3.948 \\
(3.900-3.980)\end{array}$ & & \\
\hline 53 & $\begin{array}{c}8.87 \\
(7.99-9.08)\end{array}$ & $\begin{array}{c}8.14 \\
(7.96-8.21)\end{array}$ & $\begin{array}{c}21.2 \\
(20.8-21.8)\end{array}$ & $\begin{array}{c}4.763 \\
(4.630-4.850)\end{array}$ & $\begin{array}{c}57 \\
(54-60)\end{array}$ & $(68-74)$ \\
\hline
\end{tabular}

Summary of water quality parameters measured on 24-hour old solutions for the $D$. ambigua sodium chloride chronic test. Values are expressed as means, ranges are presented in parentheses, $\mathrm{N}=10$.

\begin{tabular}{|c|c|c|c|}
\hline $\begin{array}{c}\text { Concentration } \\
(\mu \mathrm{g} / \mathrm{L})\end{array}$ & $\begin{array}{c}\text { Dissolved } \\
\text { Oxygen } \\
(\mathrm{mg} / \mathrm{L})\end{array}$ & $\mathrm{pH}$ & $\begin{array}{c}\text { Temperature } \\
(-\mathrm{C})\end{array}$ \\
\hline Control & $\begin{array}{c}8.81 \\
(8.63-9.16)\end{array}$ & $\begin{array}{c}8.11 \\
(8.00-8.21)\end{array}$ & $\begin{array}{c}21.2 \\
(20.9-21.6)\end{array}$ \\
\hline 19 & $\begin{array}{c}8.91 \\
(8.79-9.11)\end{array}$ & $\begin{array}{c}8.12 \\
(7.96-8.19)\end{array}$ & $\begin{array}{c}21.2 \\
(20.8-21.5)\end{array}$ \\
\hline 27 & $\begin{array}{c}9.01 \\
(8.76-9.24)\end{array}$ & $\begin{array}{c}8.13 \\
(7.90-8.21)\end{array}$ & $\begin{array}{c}21.0 \\
(20.1-21.7)\end{array}$ \\
\hline 33 & $\begin{array}{c}9.00 \\
(8.78-9.20)\end{array}$ & $\begin{array}{c}8.10 \\
(7.87-8.17)\end{array}$ & $\begin{array}{c}21.0 \\
(20.1-21.7)\end{array}$ \\
\hline 39 & $\begin{array}{c}9.00 \\
(8.78-9.22)\end{array}$ & $\begin{array}{c}8.11 \\
(7.87-8.20)\end{array}$ & $\begin{array}{c}21.0 \\
(19.9-21.6)\end{array}$ \\
\hline 49 & $\begin{array}{c}8.94 \\
(8.72-9.13)\end{array}$ & $\begin{array}{c}8.11 \\
(7.85-8.21)\end{array}$ & $\begin{array}{c}20.9 \\
(20.0-21.6)\end{array}$ \\
\hline 53 & $\begin{array}{c}8.96 \\
(8.78-9.22)\end{array}$ & $\begin{array}{c}8.11 \\
(7.83-8.20)\end{array}$ & $\begin{array}{c}20.9 \\
(20.0-21.5)\end{array}$ \\
\hline
\end{tabular}


APPENDIX 2 C

CHRONIC TOXICITY TEST DATA:

C. dubia EXPOSED TO COPPER SULFATE 


\section{APPENDIX 2 - ANALYTICAL CHEMISTRY DATA - COPPER}

Nominal and actual concentrations of copper in solutions used for chronic toxicity testing. Values were determined by Trace Scan ICP.

\begin{tabular}{|c|c|c|c|c|}
\hline $\begin{array}{c}\text { Nominal Cu } \\
\text { Concentration } \\
(\mu \mathrm{g} / \mathrm{L})\end{array}$ & $\begin{array}{c}\text { Measured Cu } \\
\text { Concentration } \\
\text { in Initial Test } \\
\text { Solutions } \\
(\mu \mathrm{g} / \mathrm{L})\end{array}$ & $\begin{array}{c}\text { Measured Cu } \\
\text { Concentration in } \\
\text { Mid-point Test } \\
\text { Solutions } \\
(\mu \mathrm{g} / \mathrm{L})\end{array}$ & $\begin{array}{c}\text { Measured Cu } \\
\text { Concentration in } \\
\text { Final Test } \\
\text { Solutions } \\
(\mu \mathrm{g} / \mathrm{L})\end{array}$ & $\begin{array}{c}\text { Geometric } \\
\text { Mean of Cu } \\
\text { Concentrations } \\
(\mu \mathrm{g} / \mathrm{L})\end{array}$ \\
\hline 15 & 19.2 & 20.0 & 19.1 & 19.4 \\
\hline 20 & 27.2 & 27.0 & 28.1 & 27.4 \\
\hline 25 & 33.6 & 32.6 & 31.9 & 32.7 \\
\hline 30 & 40.5 & 38.3 & 39.6 & 39.4 \\
\hline 35 & 48.3 & 51.4 & 48.4 & 49.3 \\
\hline 40 & 53.2 & 52.7 & 53.5 & 53.1 \\
\hline
\end{tabular}

${ }^{1}$ Background $\mathrm{Cu}$ concentration was less than $0.005 \mu \mathrm{g} / \mathrm{L}$. 


\section{3-BROOD CHRONIC TOXICITY TEST WITH CERIODAPHNIA \\ Survival and Reproduction Data}

Toxicant: $\quad$ Copper sulfate

Test Initiation Date: $\quad 8-20-97$

\begin{tabular}{|c|c|c|c|c|c|}
\hline \multicolumn{6}{|c|}{ Reproduction at the contol concentration } \\
\hline Rep. & Day $3 / 4$ & Day 5 & Day 6 & Day 7 & Total \\
\hline 1 & s) & of & 8 & 0) & 13 \\
\hline 2 & 4) & o) & 8 & 17. & 29 \\
\hline 3 & 6] & 0) & 8 & 14 & 28 \\
\hline 4) & 6 & 0 & 11 & 17) & 34 \\
\hline 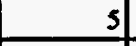 & 6 & 0) & 11 & 16 & 33 \\
\hline 6 & 6. & 0 & s) & 18 & 29 \\
\hline 7 & 5) & 0 & 9 & 14] & 28 \\
\hline 8 & 6) & 0 & 8 & 17 & 31 \\
\hline 9 & 5 & 0 & 9 & 17 & 31 \\
\hline 10 & 6 & 0 & 10 & 15 & 31 \\
\hline 11 & 6 & o & 7 & 19 & 32 \\
\hline 12 & 6 & 9 & o & 0 & 15 \\
\hline 13 & 5) & 0 & 9) & 16 & 30 \\
\hline 14 & 6 & o & 7) & 18 & 31 \\
\hline 15 & 5] & 요 & 8 & 19 & 32 \\
\hline 16 & s) & 이 & 10 & 14 & 29 \\
\hline 17 & s) & 0 & 9 & 16 & 30 \\
\hline 18 & 5) & 0 & 8 & 18 & 31 \\
\hline 19 & 5 & o) & 5 & 17. & 27 \\
\hline 20 & 0 & 이 & 10 & 14 & 24 \\
\hline \multicolumn{5}{|c|}{ Mean number of young per female } & 28.4 \\
\hline
\end{tabular}

\begin{tabular}{|c|c|c|c|c|c|}
\hline \multicolumn{6}{|c|}{ Reproduction at the $19 \mathrm{ug} / \mathrm{L}$ concentration } \\
\hline Rep. & Day $3 / 4$ & Day 5 & Day 6 & Day 7 & Total \\
\hline 1 & 6 & 인 & 7 & 5 & 18 \\
\hline 2 & 6 & 0 & 9 & 15 & 30 \\
\hline 3 & 6 & 0 & 7 & 12 & 25 \\
\hline 4 & 5 & 0 & 7 & 17 & 29 \\
\hline 5 & 5 & 0 & 11 & 15 & 31 \\
\hline 6 & 5 & 0 & 7 & 15 & 27 \\
\hline 7 & 6 & 0 & 8 & 15 & 29 \\
\hline 8 & 4 & 0 & 8 & 14 & 26 \\
\hline 9 & 4 & 0 & 10 & 10 & 24 \\
\hline 10 & 5 & o) & 7 & 9 & 21 \\
\hline 11 & 6 & 0 & 7 & 20 & 33 \\
\hline 12 & 5 & 0 & 8 & 12 & 25 \\
\hline 13 & 6 & o) & 11 & 3 & 20 \\
\hline 14 & 6 & 0 & 10 & 17 & 33 \\
\hline 15 & 3 & 0 & 8 & 12 & 23 \\
\hline 16 & 6] & 11 & 16 & 0 & 33 \\
\hline 17 & 4 & 0 & 3 & 17 & 24 \\
\hline 18 & 6 & 0 & 7 & 15 & 28 \\
\hline 19 & 5 & 0 & 8 & $\times 10$ & 23 \\
\hline 20 & 6 & 0 & 2 & 13 & 21 \\
\hline \multicolumn{5}{|c|}{ Mean number of young per female } & 26.15 \\
\hline
\end{tabular}

\begin{tabular}{|c|c|c|c|c|c|}
\hline \multicolumn{6}{|c|}{ Reproduction at the $27 \mathrm{ug} / \mathrm{L}$ concentration } \\
\hline Rep. & Day $3 / 4$ & Day 5 & Day 6 & Day 7 & Total \\
\hline 1 & 5 & 0 & 4 & 13 & 22 \\
\hline 2 & 3 & 0 & 7 & 8 & 18 \\
\hline 3 & 4 & 0 & 5 & 17 & 26 \\
\hline 4 & 5 & 0 & 5 & 12 & 22 \\
\hline 5 & 5 & 0 & 7 & 15 & 27 \\
\hline 6 & 6 & 0 & 8 & 16 & 30 \\
\hline 7 & 6 & 0 & 0 & 18 & 24 \\
\hline 8 & 4 & 0 & 10 & 9 & 23 \\
\hline 9 & 6 & 0 & 10 & 14) & 30 \\
\hline 10 & 5 & 0 & 4 & 9 & 18 \\
\hline 11 & 6 & 0 & 0 & 20 & 26 \\
\hline 12 & 5 & 0 & 4 & 15 & 24 \\
\hline 13 & 4 & 7 & $\mathrm{X}$ & $\mathrm{x}$ & 11 \\
\hline 14 & 5 & 0 & 0 & 20 & 25 \\
\hline 15 & 5 & 0 & 6 & 16 & 27 \\
\hline 16 & 5 & 8 & 11 & 0 & 24 \\
\hline 17 & 6 & 0 & 7 & 18 & 31 \\
\hline 18. & 6 & 0 & $\mathrm{x}$ & $\mathrm{x}$ & 6 \\
\hline 19 & 5 & 0 & 0 & 18 & 23 \\
\hline 20 & 5 & 0 & 10 & 18 & 33 \\
\hline \multicolumn{5}{|c|}{ Mean number of young per female } & 23.5 \\
\hline
\end{tabular}

\begin{tabular}{|c|c|c|c|c|c|}
\hline \multicolumn{6}{|c|}{ Reproduction at the $33 \mathrm{ug} / \mathrm{L}$ concentration } \\
\hline Rep. & Day 3/4 & Day 5 & Day 6 & Day 7 & Total \\
\hline 1 & 5 & 0 & 7 & 17 & 29 \\
\hline 2 & 6 & 0 & 7 & 16 & 29 \\
\hline 3 & 5 & 0 & 7 & 15 & 27 \\
\hline 4 & 5 & o) & 3 & 13) & 21 \\
\hline 5 & 4 & 3 & $x$ & $\mathbf{x}$ & 7 \\
\hline 6 & 0 & 6 & $x$ & $\mathrm{X}$ & 6 \\
\hline 7 & 6 & 0 & 8 & 11 & 25 \\
\hline 8 & 4 & 0 & 8 & 14 & 26 \\
\hline 9 & 4 & 0 & $\mathrm{x}$ & $\mathbf{x}$ & 4 \\
\hline 10 & 4 & 0 & 7 & 0 & 11 \\
\hline 11 & 4 & 0 & 9 & 7 & 20 \\
\hline 12 & 5 & 0 & $x$ & $x$ & 5 \\
\hline 13 & 6 & 0 & 6 & 16 & 28 \\
\hline 14 & 6 & 0 & 2 & 8 & 16 \\
\hline 15 & o & 14 & $\mathrm{x}$ & $\mathrm{x}$ & 14 \\
\hline 16 & 5 & 0 & 8 & 12 & 25 \\
\hline 17 & 0 & 8 & $x$ & $x$ & 8 \\
\hline 18 & 5 & 이 & 4 & 16 & 25 \\
\hline 19 & 4 & 0) & $x$ & $\mathrm{X}$ & 4 \\
\hline 20 & 0 & 10 & $\mathrm{X}$ & $x$ & 10 \\
\hline \multicolumn{5}{|c|}{ Mean number of young per female } & 17 \\
\hline
\end{tabular}

$\mathrm{X}$ denotes death of test organism 


\section{3-BROOD CHRONIC TOXICITY TEST WITH CERIODAPHNIA \\ Survival and Reproduction Data}

Toxicant: Copper sulfate

Test Initiation Date: $\quad 8-20-97$

\begin{tabular}{|c|c|c|c|c|c|}
\hline \multicolumn{6}{|c|}{ Reproduction at the 39 ug/Looncentration } \\
\hline Rep. & Day $3 / 4$ & Day 5 & Day 6 & Day 7 & Total \\
\hline 1 & 4 & 0 & 8 & 0 & 12 \\
\hline 2 & 4 & 0 & 6 & 8 & 18 \\
\hline 3 & 3 & 0 & $\mathrm{x}$ & $\mathrm{x}$ & 3 \\
\hline 4 & 6 & 0 & 4 & 9 & 19 \\
\hline 5 & 6 & 0 & 2 & 0 & 8 \\
\hline 6 & 4 & 9 & $\mathrm{x}$ & $\mathrm{x}$ & 13 \\
\hline 7 & 4 & 0 & 5 & 11 & 20 \\
\hline 8 & 4 & 0 & $\mathrm{x}$ & $\mathrm{x}$ & 4 \\
\hline 9 & 0 & 0 & $\mathrm{x}$ & $\mathrm{x}$ & 0 \\
\hline 10 & 6 & 0 & 8 & 5 & 19 \\
\hline 11 & 6 & 0 & $x$ & $\mathrm{X}$ & 6 \\
\hline 12 & 6 & 7 & $x$ & $\mathrm{x}$ & 13 \\
\hline 13 & 5 & 5 & $\mathrm{x}$ & $\mathrm{x}$ & 10 \\
\hline 14 & 6 & 9 & $\mathrm{x}$ & $x$ & 15 \\
\hline 15 & 4 & 0 & 6 & 0 & 10 \\
\hline 16 & 2 & 6 & $\mathrm{x}$ & $\mathrm{x}$ & 8 \\
\hline 17 & 5 & 9 & 11 & 0 & 25 \\
\hline 18 & 5 & 0 & 8 & 15 & 28 \\
\hline 19 & 4 & 0 & $\mathrm{x}$ & $x$ & 4 \\
\hline 20 & 0 & 0 & 0 & 0 & 0 \\
\hline \multicolumn{5}{|c|}{ Mean number of young per female } & 11.75 \\
\hline
\end{tabular}

\begin{tabular}{|c|c|c|c|c|c|}
\hline \multicolumn{6}{|c|}{ Reproduction at the $53 \mathrm{ug} / \mathrm{L}$ concentration } \\
\hline Rep. & Day $3 / 4$ & Day 5 & Day 6 & Day 7 & Total \\
\hline 1 & 3 & 0 & 0 & 15 & 18 \\
\hline 2 & 0 & 0 & 0 & 0 & 0 \\
\hline 3 & 5 & 0 & 0 & 6 & 11 \\
\hline 4 & 0 & 0 & 0 & 0 & 0 \\
\hline 5 & 0 & 0 & 0 & 0 & 0 \\
\hline 6 & 0 & 0 & 0 & 0 & 0 \\
\hline 7 & 0 & 0 & 0 & 0 & 0 \\
\hline 8 & 5 & 0 & 0 & 2 & 7 \\
\hline 9 & 0 & 0 & 0 & 0 & 0 \\
\hline 10 & 0 & 0 & 0 & 0 & 0 \\
\hline 11 & 0 & 0 & 0 & 0 & 0 \\
\hline 12 & 0 & 0 & 0 & 0 & 0 \\
\hline 13 & 0 & 0 & 0 & 0 & 0 \\
\hline 14 & 0 & 0 & 0 & 8 & 8 \\
\hline 15 & 2 & 0 & 0 & 0 & 2 \\
\hline 16 & 0 & 0 & 0 & 2 & 2 \\
\hline 17 & 0 & 0 & 0 & 0 & 0 \\
\hline 18 & 0 & 0 & 0 & 0 & 0 \\
\hline 19 & 0 & 0 & 0 & 0 & 0 \\
\hline 20 & 0 & 0 & 0 & 0 & 0 \\
\hline \multicolumn{5}{|c|}{ Mean number of young per female } & 2.4 \\
\hline
\end{tabular}

$\mathrm{X}$ denotes death of test organism

\begin{tabular}{|r|r|r|r|r|r|}
\hline \multicolumn{7}{|c|}{ Reproduction at the 49 ug/L concentration } \\
\hline Rep. & Day 3/4 & Day 5 & Day 6 & Day 7 & \multicolumn{1}{|c|}{ Total } \\
\hline 1 & 0 & 0 & 0 & 0 & 0 \\
\hline 2 & 0 & 0 & $X$ & $X$ & 0 \\
\hline 3 & 0 & 0 & 0 & 0 & 0 \\
\hline 4 & 0 & 0 & 0 & 0 & 0 \\
\hline 5 & 0 & 0 & 0 & 0 & 0 \\
\hline 6 & 0 & 0 & $X$ & $X$ & 0 \\
\hline 7 & 0 & 0 & 0 & 0 & 0 \\
\hline 8 & 0 & 0 & 0 & 0 & 0 \\
\hline 9 & 0 & 0 & $X$ & $X$ & 0 \\
\hline 10 & 0 & 0 & $X$ & $X$ & 0 \\
\hline 11 & $X$ & $X$ & $X$ & $X$ & 0 \\
\hline 12 & 0 & 0 & 0 & 0 & 0 \\
\hline 13 & 0 & 0 & 0 & 0 & 0 \\
\hline 14 & 0 & 0 & $X$ & $X$ & 0 \\
\hline 15 & 0 & 0 & 0 & 0 & 0 \\
\hline 16 & 0 & 0 & $X$ & $X$ & 0 \\
\hline 17 & 0 & 0 & 0 & 0 & 0 \\
\hline 18 & 0 & 0 & 4 & 0 & 4 \\
\hline 19 & 0 & 0 & 0 & 0 & 0 \\
\hline 20 & 0 & 0 & 4 & 0 & 4 \\
\hline Mean number of young per female & & & 0.4 \\
\hline
\end{tabular}

Mean number of young per female

$$
\text { 11 }
$$


APPENDIX $2 \mathrm{C}$

Summary of statistical data from the chronic $C$. dubia test with copper

\begin{tabular}{ccccccccc}
\hline & & \multicolumn{7}{c}{ Reproduction } \\
\cline { 5 - 9 } Group & Identification & $\mathrm{N}$ & Min & Max & Mean & Variance & SD & CV \% \\
\hline 1 & Control & 20 & 13 & 34 & 28.40 & 29.305 & 5.413 & 19.06 \\
2 & $19 \mathrm{ppb}$ & 20 & 18 & 33 & 26.15 & 20.450 & 4.522 & 17.29 \\
3 & $27 \mathrm{ppb}$ & 20 & 6 & 33 & 23.50 & 42.053 & 6.485 & 27.59 \\
4 & $33 \mathrm{ppb}$ & 20 & 4 & 29 & 17.00 & 88.737 & 9.420 & 55.41 \\
5 & $39 \mathrm{ppb}$ & 20 & 0 & 28 & 11.75 & 63.461 & 7.966 & 67.80 \\
6 & $49 \mathrm{ppb}$ & 20 & 0 & 4 & 0.40 & 1.516 & 1.231 & 307.79 \\
7 & $53 \mathrm{ppb}$ & 20 & 0 & 18 & 2.40 & 23.726 & 4.871 & 202.96 \\
\hline
\end{tabular}




\section{APPENDIX 2 C}

Summary of statistical analyses performed on data from the chronic $C$. dubia test with copper.

SUMMARY OF FISHER'S EXACT TESTS ON MORTALITY DATA

\begin{tabular}{clccc}
\hline Group & Identification & $\begin{array}{c}\text { Number } \\
\text { Exposed }\end{array}$ & $\begin{array}{c}\text { Number } \\
\text { Dead }\end{array}$ & $\begin{array}{c}\text { Sigificant } \\
(\mathrm{p}=0.05)\end{array}$ \\
\hline 1 & Control & 20 & 0 & \\
2 & $19 \mathrm{ppb}$ & 20 & 0 & $*$ \\
3 & $27 \mathrm{ppb}$ & 20 & 2 & $*$ \\
4 & $33 \mathrm{ppb}$ & 20 & 8 & $*$ \\
5 & $39 \mathrm{ppb}$ & 20 & 10 & $*$ \\
6 & $49 \mathrm{ppb}$ & 20 & 7 & 0 \\
\hline
\end{tabular}

Note: Concentrations with significant mortality were excluded from further statisitcal analysis. 


\section{APPENDIX 2 C}

Summary of statistical analyses performed on data from the chronic C. dubia test with copper.

CHI-SQUARE TEST FOR NORMALITY: ACTUAL AND EXPECTED FREQUENCIES

\begin{tabular}{llllll}
\hline INTERVAL & $<-1.5$ & -1.5 to $<-0.5$ & -0.5 to 0.5 & $>0.5$ to 1.5 & $>1.5$ \\
\hline EXPECTED & 5.360 & 19.360 & 30.560 & 19.360 & 5.360 \\
OBSERVED & 5 & 8 & 46 & 16 & 5 \\
\hline
\end{tabular}

Calculated Chi-Square goodness of fit test statistic $=15.0981$

Table Chi-Square value $($ alpha $=0.01)=13.277$

Data FAIL normality test. No need to continue analysis.

\begin{tabular}{ccccccc}
\multicolumn{2}{l}{ STEEL'S MANY-ONE RANK TEST } & - & Ho:Control<Treatment & \\
\hline Group & $\begin{array}{c}\text { Identification } \\
*\end{array}$ & Mean & $\begin{array}{c}\text { Rank } \\
\text { Sum }\end{array}$ & $\begin{array}{c}\text { Critical } \\
\text { Value }\end{array}$ & df & Significant \\
\hline 1 & Control & 28.40 & & & & \\
2 & $19 \mathrm{ppb}$ & 26.15 & 338.5 & 333.00 & 20 & \\
3 & $27 \mathrm{ppb}$ & 23.50 & 297.5 & 333.00 & 20 & $*$ \\
4 & $53 \mathrm{ppb}$ & 2.40 & 212.0 & 333.00 & 20 & $*$ \\
\hline
\end{tabular}

Critical values use $k=5$, are 1 tailed, and alpha $=0.05$ 
Summary of water quality parameters measured on daily renewal solutions for the $C$. dubia copper sulfate chronic test. Values are expressed as means, ranges are presented in parentheses, $\mathrm{N}=7$.

\begin{tabular}{|c|c|c|c|c|c|c|}
\hline $\begin{array}{c}\text { Concentration } \\
(\mu \mathrm{g} / \mathrm{L})\end{array}$ & $\begin{array}{c}\text { Dissolved } \\
\text { Oxygen } \\
\text { (mg/L) }\end{array}$ & $\mathbf{p H}$ & $\begin{array}{c}\text { Temperature } \\
\left({ }^{\circ} \mathrm{C}\right)\end{array}$ & $\begin{array}{l}\text { Conductivity } \\
\text { (ms/cm) }\end{array}$ & $\begin{array}{c}\text { Hardness } \\
\left(\mathrm{mg} / \mathrm{L} \text { as } \mathrm{CaCO}_{3}\right)\end{array}$ & $\begin{array}{c}\text { Alkalinity } \\
\left(\mathrm{mg} / \mathrm{L} \text { as } \mathrm{CaCO}_{3}\right)\end{array}$ \\
\hline Control & $\begin{array}{c}8.48 \\
(8.32-8.72) \\
\end{array}$ & $\begin{array}{c}8.25 \\
(8.20-8.30) \\
\end{array}$ & $\begin{array}{c}24.6 \\
(24.0-25.1)\end{array}$ & $\begin{array}{c}0.291 \\
(0.276-0.323)\end{array}$ & $\begin{array}{c}65 \\
(64-68)\end{array}$ & $\begin{array}{c}69 \\
(66-72)\end{array}$ \\
\hline 19 & $\begin{array}{c}8.18 \\
(7.69-8.51)\end{array}$ & $\begin{array}{c}8.29 \\
(8.25-8.35)\end{array}$ & $\begin{array}{c}24.4 \\
(24.1-25.2)\end{array}$ & $\begin{array}{c}0.293 \\
(0.277-0.330)\end{array}$ & & \\
\hline 27 & $\begin{array}{c}8.23 \\
(7.56-8.45)\end{array}$ & $\begin{array}{c}8.29 \\
(8.26-8.32)\end{array}$ & $\begin{array}{c}24.9 \\
(24.0-25.5)\end{array}$ & $\begin{array}{c}0.300 \\
(0.278-0.332)\end{array}$ & & \\
\hline 33 & $\begin{array}{c}8.22 \\
(7.95-8.37)\end{array}$ & $\begin{array}{c}8.31 \\
(8.24-8.36)\end{array}$ & $\begin{array}{c}24.5 \\
(24.1-25.3)\end{array}$ & $\begin{array}{c}0.298 \\
(0.273-0.335)\end{array}$ & & \\
\hline 39 & $\begin{array}{c}8.20 \\
(7.95-8.57)\end{array}$ & $\begin{array}{c}8.31 \\
(8.27-8.36)\end{array}$ & $\begin{array}{c}24.5 \\
(24.0-25.1)\end{array}$ & $\begin{array}{c}0.298 \\
(0.276-0.334)\end{array}$ & & \\
\hline 49 & $\begin{array}{c}8.18 \\
(7.96-8.49)\end{array}$ & $\begin{array}{c}8.34 \\
(8.30-8.38)\end{array}$ & $\begin{array}{c}24.6 \\
(24.2-25.0)\end{array}$ & $\begin{array}{c}0.295 \\
(0.277-0.354)\end{array}$ & . & \\
\hline 53 & $\begin{array}{c}8.20 \\
(7.89-8.46)\end{array}$ & $\begin{array}{c}8.31 \\
(8.28-8.32)\end{array}$ & $\begin{array}{c}24.5 \\
(24.2-25.0)\end{array}$ & $\begin{array}{c}0.296 \\
(0.273-0.358)\end{array}$ & $\begin{array}{c}65 \\
(64-66)\end{array}$ & $\begin{array}{c}76 \\
(74-78)\end{array}$ \\
\hline
\end{tabular}

Summary of water quality parameters measured on 24-hour old solutions for the $C$. dubia copper sulfate chronic test. Values are expressed as means, ranges are presented in parentheses, $N=7$.

\begin{tabular}{|c|c|c|c|}
\hline $\begin{array}{c}\text { Concentration } \\
(\mu \mathrm{g} / \mathrm{L})\end{array}$ & $\begin{array}{c}\text { Dissolved } \\
\text { Oxygen } \\
(\mathrm{mg} / \mathrm{L})\end{array}$ & $\mathrm{pH}$ & $\begin{array}{c}\text { Temperature } \\
(\cdot \mathrm{C})\end{array}$ \\
\hline Control & $\begin{array}{c}7.49 \\
(7.35-7.64)\end{array}$ & $\begin{array}{c}8.38 \\
(8.29-8.45)\end{array}$ & $\begin{array}{c}25.0 \\
(24.6-25.4)\end{array}$ \\
\hline 19 & $\begin{array}{c}7.71 \\
(7.48-7.95)\end{array}$ & $\begin{array}{c}8.35 \\
(8.23-8.45)\end{array}$ & $\begin{array}{c}24.6 \\
(24.3-25.2)\end{array}$ \\
\hline 27 & $\begin{array}{c}7.58 \\
(7.35-7.84)\end{array}$ & $\begin{array}{c}8.36 \\
(8.28-8.42)\end{array}$ & $\begin{array}{c}24.6 \\
(24.1-25.1)\end{array}$ \\
\hline 33 & $\begin{array}{c}7.70 \\
(7.36-8.12)\end{array}$ & $\begin{array}{c}8.36 \\
(8.27-8.43)\end{array}$ & $\begin{array}{c}24.6 \\
(24.1-25.1)\end{array}$ \\
\hline 39 & $\begin{array}{c}7.68 \\
(7.48-7.91)\end{array}$ & $\begin{array}{c}8.34 \\
(8.27-8.42)\end{array}$ & $\begin{array}{c}24.5 \\
(24.1-24.8)\end{array}$ \\
\hline 49 & $\begin{array}{c}7.74 \\
(7.38-8.04)\end{array}$ & $\begin{array}{c}8.38 \\
(8.29-8.48)\end{array}$ & $\begin{array}{c}24.5 \\
(24.1-25.1)\end{array}$ \\
\hline 53 & $\begin{array}{c}7.70 \\
(7.35-7.95)\end{array}$ & $\begin{array}{c}8.41 \\
(8.37-8.46)\end{array}$ & $\begin{array}{c}24.5 \\
(24.1-25.2)\end{array}$ \\
\hline
\end{tabular}


APPENDIX 2 D

\section{CHRONIC TOXICITY TEST DATA:}

D. ambigua EXPOSED TO COPPER SULFATE 


\section{APPENDIX 2 - ANALYTICAL CHEMISTRY DATA - COPPER}

Nominal and actual concentrations of copper in solutions used for chronic toxicity testing. Values were determined by Trace Scan ICP.

\begin{tabular}{|c|c|c|c|c|}
\hline $\begin{array}{c}\text { Nominal Cu } \\
\text { Concentration } \\
(\mu \mathrm{g} / \mathrm{L})\end{array}$ & $\begin{array}{c}\text { Measured Cu } \\
\text { Concentration } \\
\text { in Initial Test } \\
\text { Solutions } \\
(\mu \mathrm{g} / \mathrm{L})\end{array}$ & $\begin{array}{c}\text { Measured Cu } \\
\text { Concentration in } \\
\text { Mid-point Test } \\
\text { Solutions } \\
(\mu \mathrm{g} / \mathrm{L})\end{array}$ & $\begin{array}{c}\text { Measured Cu } \\
\text { Concentration in } \\
\text { Final Test } \\
\text { Solutions } \\
(\mu \mathrm{g} / \mathrm{L})\end{array}$ & $\begin{array}{c}\text { Geometric } \\
\text { Mean of Cu } \\
\text { Concentrations } \\
(\mu \mathrm{g} / \mathrm{L})\end{array}$ \\
\hline 15 & 19.2 & 20.0 & 19.1 & 19.4 \\
\hline 20 & 27.2 & 27.0 & 28.1 & 27.4 \\
\hline 25 & 33.6 & 32.6 & 31.9 & 32.7 \\
\hline 30 & 40.5 & 38.3 & 39.6 & 39.4 \\
\hline 35 & 48.3 & 51.4 & 48.4 & 49.3 \\
\hline 40 & 53.2 & 52.7 & 53.5 & 53.1 \\
\hline
\end{tabular}

${ }^{1}$ Background $\mathrm{Cu}$ concentration was less than $0.005 \mu \mathrm{g} / \mathrm{L}$. 


\section{3-BROOD CHRONIC TOXICITY TEST WITH DAPHNIA AMBIGUA \\ Survival and Reproduction Data}

Toxicant: copper sulfate

Test Initiation Date: $8-20-97$

\begin{tabular}{|c|c|c|c|c|c|c|}
\hline \multicolumn{7}{|c|}{ Reproduction at the control concentration } \\
\hline Rep. & Day $5 / 6$ & Day 7 & Day 8 & Day 9 & Day 10 & Total \\
\hline 1) & 0 & 0 & 6 & 0 & $\mathrm{X}$ & 6 \\
\hline 2) & 4 & 0 & 10 & 0 & 7 & 21 \\
\hline 3 & 4 & 0 & 10 & 0 & 11 & 25 \\
\hline 4 & 4 & 0 & 0 & 10 & 4 & 18 \\
\hline 5 & $4 \mid$ & 0 & 14) & 0 & 10 & 28 \\
\hline 6 & 0 & 0 & 7 & 0 & 15 & 22 \\
\hline 7 & 3 & 0 & 5 & 5 & 3 & 16 \\
\hline 8 & s) & 0 & 10 & 0 & 10 & 25 \\
\hline 9 & 4) & 0 & 7) & 0 & 0 & 11 \\
\hline 10 & 4 & 0 & 12 & 0 & 12 & 28 \\
\hline 11 & $4 \mid$ & 0 & 이 & 10 & 9 & 23 \\
\hline 12. & 0 & 0 & 6 & 4 & 10 & 20 \\
\hline 13 & 3 & 0 & of & 13 & 10 & 26 \\
\hline 14 & 5 & 0 & 7 & o) & 5 & 17 \\
\hline 15 & 3 & 0 & 7 & o & 7 & 17 \\
\hline 16 & 3 & 0 & 5 & o) & 1 & 9 \\
\hline 17 & 4) & 0 & 이 & 8 & 8 & 20 \\
\hline 18 & 5 & 0 & 7 & 0 & 10 & 22 \\
\hline 19 & 0) & 0 & 5 & 8 & 7 & 20 \\
\hline 20 & 2 & 0 & 4 & 6 & 7 & 19 \\
\hline \multicolumn{6}{|c|}{ Mean number of young per female } & 19.65 \\
\hline
\end{tabular}

\begin{tabular}{|r|r|r|r|r|r|r|}
\hline Reproduction at the 19 ug/L concentration \\
\hline Rep. & Day 5/6 & Day 7 & Day 8 & Day 9 & Day 10 & Total \\
\hline 1 & 4 & 0 & 0 & 0 & 11 & 15 \\
\hline 2 & 5 & 0 & 0 & 8 & 9 & 22 \\
\hline 3 & 3 & 0 & 10 & 0 & 3 & 16 \\
\hline 4 & 4 & 0 & 10 & 0 & 9 & 23 \\
\hline 5 & 4 & 0 & 10 & 0 & 8 & 22 \\
\hline 6 & 5 & 0 & 0 & 0 & 3 & 8 \\
\hline 7 & 5 & 0 & 0 & 0 & 8 & 13 \\
\hline 8 & 6 & 0 & 0 & 3 & 5 & 14 \\
\hline 9 & 5 & 12 & 0 & 0 & 10 & 27 \\
\hline 10 & 5 & 4 & 0 & 6 & 5 & 20 \\
\hline 11 & 3 & 2 & 0 & 0 & 4 & 9 \\
\hline 12 & 4 & 1 & 0 & 4 & 7 & 16 \\
\hline 13 & 6 & 6 & 0 & 0 & 10 & 22 \\
\hline 14 & 4 & 0 & 3 & 0 & 10 & 17 \\
\hline 15 & 6 & 0 & 5 & 0 & 8 & 19 \\
\hline 16 & 0 & 0 & 6 & 0 & 9 & 15 \\
\hline 17 & 4 & 0 & 5 & 0 & 5 & 14 \\
\hline 18 & 4 & 0 & 5 & 0 & 0 & 9 \\
\hline 19 & 5 & 0 & 0 & 0 & 4 & 9 \\
\hline 20 & 5 & 0 & 6 & 0 & 3 & 14 \\
\hline Mean number of young per female & & & 16.2 \\
\hline
\end{tabular}

\begin{tabular}{|r|r|r|r|r|r|r|}
\hline Reproduction at the 27 ug/L concentration \\
\hline Rep. & Day 5/6 & Day 7 & Day 8 & Day 9 & Day 10 & Total \\
\hline 1 & 4 & 0 & 4 & 5 & 0 & 13 \\
\hline 2 & 5 & 0 & 8 & 1 & 9 & 23 \\
\hline 3 & 4 & 0 & 11 & 0 & 7 & 22 \\
\hline 4 & 3 & 0 & 6 & 0 & 4 & 13 \\
\hline 5 & 3 & 0 & 0 & 0 & 0 & 3 \\
\hline 6 & 5 & 0 & 0 & 4 & 0 & 9 \\
\hline 7 & 0 & 0 & 3 & $X$ & $X$ & 3 \\
\hline 8 & 4 & 0 & 0 & 10 & 10 & 24 \\
\hline 9 & 4 & 0 & 0 & 2 & 0 & 6 \\
\hline 10 & 0 & 0 & 3 & 0 & 4 & 7 \\
\hline 11 & 5 & 0 & 9 & 0 & 0 & 14 \\
\hline 12 & 4 & 0 & 7 & 0 & 5 & 16 \\
\hline 13 & 3 & 0 & 7 & 0 & 5 & 15 \\
\hline 14 & 0 & 0 & 6 & 0 & 12 & 18 \\
\hline 15 & 0 & 0 & 7 & 0 & 12 & 19 \\
\hline 16 & 5 & 0 & 8 & 0 & 0 & 13 \\
\hline 17 & 4 & 0 & 7 & 0 & 6 & 17 \\
\hline 18 & 0 & 0 & 4 & 0 & 9 & 13 \\
\hline 19 & 4 & 0 & 8 & 0 & 7 & 19 \\
\hline 20 & 0 & 0 & 9 & 0 & 7 & 16 \\
\hline Mean number of young per female & & & 14.15 \\
\hline
\end{tabular}

\begin{tabular}{|c|c|c|c|c|c|c|}
\hline \multicolumn{7}{|c|}{ Reproduction at the $33 \mathrm{ug} / \mathrm{L}$ concentration } \\
\hline Rep. & Day $5 / 6$ & Day 7 & Day 8 & Day 9 & Day 10 & Total \\
\hline 1 & 0 & 0 & 0 & 0 & 0 & 0 \\
\hline 2 & 0 & 0 & 0 & 6 & 0 & 6 \\
\hline 3 & 0 & 0 & 0 & 3 & 0 & 3 \\
\hline 4 & 0 & 4 & 0 & 0 & 0 & 4 \\
\hline 5 & 0 & 0 & 0 & 0 & 0 & 0 \\
\hline 6 & 0 & 5 & 0 & 6 & 0 & 11 \\
\hline 7 & 4 & 0 & 0 & 1 & 0 & 5 \\
\hline 8 & 4 & 0 & 0 & 5 & 0 & 9 \\
\hline 9 & 5 & 11 & 0 & 0 & 5 & 21 \\
\hline 10 & 4 & 0 & 0 & 6 & 0 & 10 \\
\hline 11 & 3 & 0 & 0 & 0 & 0 & 3 \\
\hline 12 & 3 & 0 & 0 & 2 & 0 & 5 \\
\hline 13 & 4 & 0 & 0 & 0 & 3 & 7 \\
\hline 14 & 0 & 4 & 0 & 7 & 0 & 11 \\
\hline 15 & 4 & 4 & 0 & 0 & 0 & 8 \\
\hline 16 & 3 & 0 & 0 & 8 & 0 & 11 \\
\hline 17 & 3 & 7 & 0 & 0 & 0 & 10 \\
\hline 18 & 5 & 0 & 0 & 5 & 0 & 10 \\
\hline 19 & 0 & 5 & 0 & 9 & 0 & 14 \\
\hline 20 & 3 & 0 & 0 & 0 & 0 & 3 \\
\hline \multicolumn{6}{|c|}{ Mean number of young per female } & 7.55 \\
\hline
\end{tabular}

$\mathrm{X}$ denotes death of test organism 


\section{3-BROOD CHRONIC TOXICITY TEST WITH DAPHNIA AMBIGUA \\ Survival and Reproduction Data}

Toxicant: copper sulfate

Test Initiation Date: $8-20-97$

\begin{tabular}{|r|r|r|r|r|r|r|}
\hline \multicolumn{7}{|c|}{ Reproduction at the 39 ug/L concentration } \\
\hline Rep. & Day 5/6 & Day 7 & Day 8 & Day 9 & Day 10 & Total \\
\hline 1 & $\mathrm{X}$ & $\mathrm{X}$ & $\mathrm{X}$ & $\mathrm{X}$ & $\mathrm{X}$ & 0 \\
\hline 2 & 4 & 0 & 6 & 0 & 0 & 10 \\
\hline 3 & 0 & 0 & 3 & 0 & 0 & 3 \\
\hline 4 & 0 & 0 & 3 & 7 & 0 & 10 \\
\hline 5 & 3 & 0 & 0 & 0 & 0 & 3 \\
\hline 6 & 4 & 0 & 0 & 0 & 0 & 4 \\
\hline 7 & $\mathrm{X}$ & $\mathrm{X}$ & $\mathrm{X}$ & $\mathrm{X}$ & $\mathrm{X}$ & 0 \\
\hline 8 & $\mathrm{X}$ & $\mathrm{X}$ & $\mathrm{X}$ & $\mathrm{X}$ & $\mathrm{X}$ & 0 \\
\hline 9 & 3 & 0 & 0 & 5 & 0 & 8 \\
\hline 10 & $\mathrm{X}$ & $\mathrm{X}$ & $\mathrm{X}$ & $\mathrm{X}$ & $\mathrm{X}$ & 0 \\
\hline 11 & 2 & 0 & 4 & 0 & 0 & 6 \\
\hline 12 & 3 & 0 & 0 & 0 & 0 & 3 \\
\hline 13 & 0 & 0 & 0 & 0 & 0 & 0 \\
\hline 14 & $\mathrm{X}$ & $\mathrm{X}$ & $\mathrm{X}$ & $\mathrm{X}$ & $\mathrm{X}$ & 0 \\
\hline 15 & 2 & 0 & 3 & 0 & 0 & 5 \\
\hline 16 & 4 & 0 & 0 & 0 & 2 & 6 \\
\hline 17 & $\mathrm{X}$ & $\mathrm{X}$ & $\mathrm{X}$ & $\mathrm{X}$ & $\mathrm{X}$ & 0 \\
\hline 18 & 2 & 0 & 0 & 0 & 5 & 7 \\
\hline 19 & $\mathrm{X}$ & $\mathrm{X}$ & $\mathrm{X}$ & $\mathrm{X}$ & $\mathrm{X}$ & 0 \\
\hline 20 & 4 & 0 & 0 & 0 & 0 & 4 \\
\hline Mean number of young per female & & & 3.45 \\
\hline
\end{tabular}

\begin{tabular}{|c|c|c|c|c|c|c|}
\hline \multicolumn{7}{|c|}{ Reproduction at the $49 \mathrm{ug} / \mathrm{L}$ concentration } \\
\hline Rep. & Day $5 / 6$ & Day 7 & Day 8 & Day 9 & Day 10 & Total \\
\hline 1 & $\mathbf{0}$ & 0 & 0 & 0 & 0 & 0 \\
\hline 2 & $\mathrm{x}$ & $x$ & $\mathrm{x}$ & $\mathrm{x}$ & $\mathbf{x}$ & 0 \\
\hline 3 & $\mathrm{x}$ & $x$ & $\mathrm{x}$ & $\mathrm{x}$ & $\mathbf{x}$ & 0 \\
\hline 4 & $\mathrm{x}$ & $\mathbf{X}$ & $\mathrm{x}$ & $\mathrm{x}$ & $\mathrm{x}$ & 0 \\
\hline 5 & $\mathbf{x}$ & $\mathbf{x}$ & $\mathbf{x}$ & $\mathbf{x}$ & $\mathbf{x}$ & 0 \\
\hline 6 & 0 & 0 & 4 & 3 & $\mathbf{0}$ & 7 \\
\hline 7 & $\mathbf{x}$ & $\mathrm{x}$ & $\mathrm{x}$ & $\mathrm{x}$ & $\mathrm{x}$ & 0 \\
\hline 8 & 0 & 0 & 0 & 0 & 0 & 0 \\
\hline 9 & $\mathbf{x}$ & $\mathbf{x}$ & $\mathbf{x}$ & $\mathbf{x}$ & $\mathbf{x}$ & 0 \\
\hline 10 & 0 & $\mathbf{0}$ & 0 & 4 & 0 & 4 \\
\hline 11 & 4 & 0 & 7 & 0 & 0 & 11 \\
\hline 12 & $\mathrm{x}$ & $\mathrm{X}$ & $x$ & $\mathrm{x}$ & $\mathrm{x}$ & 0 \\
\hline 13 & 0 & 0 & 4 & 0 & 0 & 4 \\
\hline 14 & $\mathrm{x}$ & $\mathrm{X}$ & $x$ & $\mathrm{X}$ & $\mathbf{x}$ & 0 \\
\hline 15 & 3 & 0 & 2 & 6 & 0 & 11 \\
\hline 16 & 0 & 0 & 0 & 0 & 0 & 0 \\
\hline 17 & ol & 0 & 0 & 0 & 0 & 0 \\
\hline 18 & 3 & 0 & 3 & 0 & 0 & 6 \\
\hline 19 & $\mathrm{x}$ & $X$ & $\mathrm{x}$ & $\mathrm{X}$ & $\mathbf{x}$ & 0 \\
\hline 20 & 3 & 0 & 6 & 0 & 0 & 9 \\
\hline \multicolumn{6}{|c|}{ Mean number of young per female } & 2.6 \\
\hline
\end{tabular}

\begin{tabular}{|r|r|r|r|r|r|r|}
\hline Reproduction at the 53 ug/L concentration \\
\hline Rep. & Day 5/6 & Day 7 & Day 8 & Day 9 & Day 10 & Total \\
\hline 1 & $\mathrm{X}$ & $\mathrm{X}$ & $\mathrm{X}$ & $\mathrm{X}$ & $\mathrm{X}$ & 0 \\
\hline 2 & 0 & 0 & 0 & 0 & 0 & 0 \\
\hline 3 & 0 & 0 & 0 & 0 & 0 & 0 \\
\hline 4 & $\mathrm{X}$ & $\mathrm{X}$ & $\mathrm{X}$ & $\mathrm{X}$ & $\mathrm{X}$ & 0 \\
\hline 5 & 0 & 0 & 0 & 0 & 0 & 0 \\
\hline 6 & $\mathrm{X}$ & $\mathrm{X}$ & $\mathrm{X}$ & $\mathrm{X}$ & $\mathrm{X}$ & 0 \\
\hline 7 & $\mathrm{X}$ & $\mathrm{X}$ & $\mathrm{X}$ & $\mathrm{X}$ & $\mathrm{X}$ & 0 \\
\hline 8 & 0 & 0 & 2 & 0 & 0 & 2 \\
\hline 9 & 0 & $\mathrm{X}$ & $\mathrm{X}$ & $\mathrm{X}$ & $\mathrm{X}$ & 0 \\
\hline 10 & 0 & $\mathrm{X}$ & $\mathrm{X}$ & $\mathrm{X}$ & $\mathrm{X}$ & 0 \\
\hline 11 & $\mathrm{X}$ & $\mathrm{X}$ & $\mathrm{X}$ & $\mathrm{X}$ & $\mathrm{X}$ & 0 \\
\hline 12 & $\mathrm{X}$ & $\mathrm{X}$ & $\mathrm{X}$ & $\mathrm{X}$ & $\mathrm{X}$ & 0 \\
\hline 13 & 0 & 0 & 0 & 0 & 0 & 0 \\
\hline 14 & $\mathrm{X}$ & $\mathrm{X}$ & $\mathrm{X}$ & $\mathrm{X}$ & $\mathrm{X}$ & 0 \\
\hline 15 & 0 & 0 & 0 & 0 & 0 & 0 \\
\hline 16 & $\mathrm{X}$ & $\mathrm{X}$ & $\mathrm{X}$ & $\mathrm{X}$ & $\mathrm{X}$ & 0 \\
\hline 17 & $\mathrm{X}$ & $\mathrm{X}$ & $\mathrm{X}$ & $\mathrm{X}$ & $\mathrm{X}$ & 0 \\
\hline 18 & 0 & 0 & 0 & 0 & 0 & 0 \\
\hline 19 & 0 & 0 & 2 & 0 & 0 & 2 \\
\hline 20 & 0 & 0 & 0 & 0 & 0 & 0 \\
\hline Mean number of young per female & & & 0.2 \\
\hline
\end{tabular}

$\mathrm{X}$ denotes death of test organism 
APPENDIX 2 D

Summary of statistical data from the chronic $D$. ambigua test with copper

\begin{tabular}{ccccccccc}
\hline \multirow{2}{*}{ Group } & Identification & $\mathrm{N}$ & \multicolumn{7}{c}{ Reproduction } \\
\cline { 5 - 9 } & & Min & Max & Mean & Variance & SD & CV \% \\
\hline 1 & Control & 20 & 6 & 28 & 19.65 & 35.082 & 5.923 & 30.14 \\
2 & $19 \mathrm{ppb}$ & 20 & 8 & 27 & 16.20 & 28.274 & 5.317 & 32.82 \\
3 & $27 \mathrm{ppb}$ & 20 & 3 & 24 & 14.15 & 37.503 & 6.124 & 43.28 \\
4 & $33 \mathrm{ppb}$ & 20 & 0 & 21 & 7.55 & 25.418 & 5.042 & 66.78 \\
5 & $39 \mathrm{ppb}$ & 20 & 0 & 10 & 3.45 & 12.155 & 3.486 & 101.06 \\
6 & $49 \mathrm{ppb}$ & 20 & 0 & 11 & 2.60 & 16.042 & 4.005 & 154.05 \\
7 & $53 \mathrm{ppb}$ & 20 & 0 & 2 & 0.20 & 0.379 & 0.616 & 307.79 \\
\hline
\end{tabular}




\section{APPENDIX 2 D}

Summary of statistical analyses performed on data from the chronic $D$. ambigua test with copper.

\section{SUMMARY OF FISHER'S EXACT TESTS ON MORTALITY DATA}

\begin{tabular}{clccc}
\hline Group & Identification & $\begin{array}{c}\text { Number } \\
\text { Exposed }\end{array}$ & $\begin{array}{c}\text { Number } \\
\text { Dead }\end{array}$ & $\begin{array}{c}\text { Sigificant } \\
(\mathrm{p}=0.05)\end{array}$ \\
\hline 1 & Control & 20 & 1 & \\
2 & $19 \mathrm{ppb}$ & 20 & 0 & \\
3 & $27 \mathrm{ppb}$ & 20 & 1 & $*$ \\
4 & $33 \mathrm{ppb}$ & 20 & 0 & $*$ \\
5 & $39 \mathrm{ppb}$ & 20 & 7 & $*$ \\
6 & $49 \mathrm{ppb}$ & 20 & 9 & \\
\hline
\end{tabular}

Note: Concentrations with significant mortality were excluded from further statisitcal analysis. 


\section{APPENDIX 2 D}

Summary of statistical analyses performed on data from the chronic $D$. ambigua test with copper.

CHI-SQUARE TEST FOR NORMALITY: ACTUAL AND EXPECTED FREQUENCIES

\begin{tabular}{llllll}
\hline INTERVAL & $<-1.5$ & -1.5 to $<-0.5$ & -0.5 to 0.5 & $>0.5$ to 1.5 & $>1.5$ \\
\hline EXPECTED & 5.360 & 19.360 & 30.560 & 19.360 & 5.360 \\
OBSERVED & 5 & 17 & 34 & 21 & 3 \\
\hline
\end{tabular}

Calculated Chi-Square goodness of fit test statistic $=1.8771$

Table Chi-Square value $($ alpha $=0.01)=13.277$

Data PASS normality test. Continue analysis.

\section{BARTLETT'S TEST FOR HOMOGENEITY OF VARIANCE}

Calculated B1 statistic $=0.92$

Table Chi-square value $=11.34($ alpha $=0.01, \mathrm{df}=3)$

Table Chi-square value $=7.81($ alpha $=0.05, \mathrm{df}=3)$

Data PASS B1 homogeneity test at 0.01 level. 


\section{APPENDIX 2 D}

Summary of statistical analyses performed on data from the chronic $D$. ambigua test with copper.

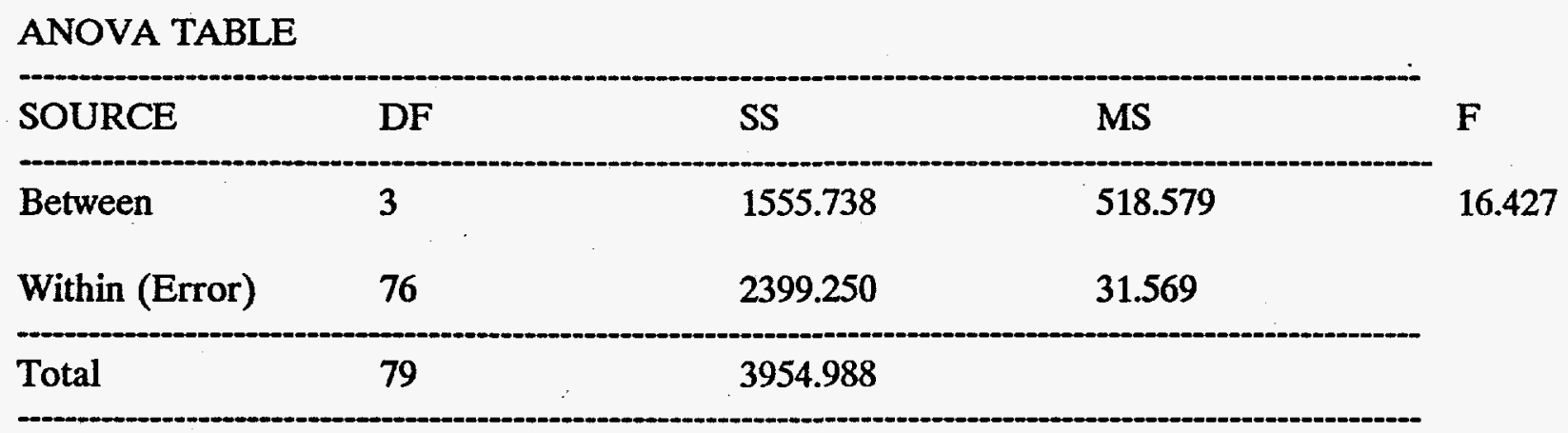

Critical $\mathrm{F}$ value $=2.76(0.05,3,60)$

Since $F>$ Critical F REJECT Ho: All equal

DUNNETT'S TEST - TABLE 1 OF 2 Ho:Control < Treatment

\begin{tabular}{llllll} 
GROUP IDENTIFICATION & \multicolumn{2}{l}{ TRANSFORMED } & \multicolumn{2}{l}{ MEAN CALCULATED IN } \\
& MEAN & & \\
& & & & \\
\hline 1 & CRIGINAL UNITS & T STAT & SIG \\
3 & $19 \mathrm{ppb}$ & 19.650 & 19.650 & 1.942 & \\
4 & $27 \mathrm{ppb}$ & 16.200 & 16.200 & 3.096 & $*$ \\
4 & $33 \mathrm{ppb}$ & 7.550 & 14.150 & 6.810 & $*$
\end{tabular}

Dunnett table value $=2.10 \quad(1$ Tailed Value, $P=0.05, \mathrm{df}=60,3)$

DUNNETT'S TEST - TABLE 2 OF 2 Ho:Control < Treatment

\begin{tabular}{|c|c|c|c|c|c|}
\hline GROUP & IDENTIFICATION & REPS & $\begin{array}{l}\text { Minimum Sig Diff } \\
\text { (IN ORIG. UNITS) }\end{array}$ & $\begin{array}{l}\% \text { of } \\
\text { CONTROL }\end{array}$ & $\begin{array}{l}\text { DIFFERI } \\
\text { FROM } \\
\text { CONTR }\end{array}$ \\
\hline 1 & control & 20 & & & \\
\hline 2 & $19 \mathrm{ppb}$ & 20 & 3.731 & 19.0 & 3.450 \\
\hline 3 & $27 \mathrm{ppb}$ & 20 & 3.731 & 19.0 & 5.500 \\
\hline 4 & $33 \mathrm{ppb}$ & 20 & 3.731 & 19.0 & \\
\hline
\end{tabular}


Summary of water quality parameters measured on daily renewal solutions for the $D$. ambigua copper sulfate chronic test. Values are expressed as means, ranges are presented in parentheses, $\mathbf{N}=10$.

\begin{tabular}{|c|c|c|c|c|c|c|}
\hline $\begin{array}{c}\text { Concentration } \\
(\mathrm{Mg} / \mathrm{L})\end{array}$ & $\begin{array}{l}\text { Dissolved } \\
\text { Orygen } \\
(\mathrm{mg} / \mathrm{L})\end{array}$ & pH & $\begin{array}{c}\text { Temperature } \\
\left({ }^{\circ} \mathrm{C}\right)\end{array}$ & $\begin{array}{l}\text { Conductivity } \\
\text { (ms/cm) }\end{array}$ & $\begin{array}{c}\text { Hardmess } \\
\left(\mathrm{mg} / \mathrm{L} \text { as } \mathrm{CaCO}_{3}\right)\end{array}$ & $\begin{array}{c}\text { Alkalinity } \\
\left(\mathrm{mg} / \mathrm{L} \text { as } \mathrm{CaCO}_{3}\right)\end{array}$ \\
\hline Control & $\begin{array}{c}8.97 \\
(8.74-9.36)\end{array}$ & $\begin{array}{c}8.35 \\
(8.25-8.42)\end{array}$ & $\begin{array}{c}21.1 \\
(20.5-21.4)\end{array}$ & $\begin{array}{c}0.289 \\
(0.276-0.323)\end{array}$ & $\begin{array}{c}65 \\
(64-68)\end{array}$ & $\begin{array}{c}69 \\
(66-72)\end{array}$ \\
\hline 19 & $\begin{array}{c}8.97 \\
(8.73-9.39)\end{array}$ & $\begin{array}{c}8.34 \\
(8.23-8.44)\end{array}$ & $\begin{array}{c}21.0 \\
(20.2-21.5)\end{array}$ & $\begin{array}{c}0.294 \\
(0.276-0.330)\end{array}$ & & \\
\hline 27 & $\begin{array}{c}8.96 \\
(8.64-9.12)\end{array}$ & $\begin{array}{c}8.31 \\
(8.21-8.45)\end{array}$ & $\begin{array}{c}21.1 \\
(20.5-21.6)\end{array}$ & $\begin{array}{c}0.296 \\
(0.277-0.332)\end{array}$ & & \\
\hline 33 & $\begin{array}{c}8.90 \\
(8.54-9.14)\end{array}$ & $\begin{array}{c}8.31 \\
(8.24-8.42)\end{array}$ & $\begin{array}{c}21.0 \\
(20.1-21.5)\end{array}$ & $\begin{array}{c}0.300 \\
(0.273-0.335)\end{array}$ & & \\
\hline 39 & $\begin{array}{c}8.96 \\
(8.65-9.39)\end{array}$ & $\begin{array}{c}8.36 \\
(8.25-8.45)\end{array}$ & $\begin{array}{c}21.0 \\
(20.4-21.4)\end{array}$ & $\begin{array}{c}8.296 \\
(0.276-0.334)\end{array}$ & & \\
\hline 49 & $\begin{array}{c}8.96 \\
(8.65-9.28)\end{array}$ & $\begin{array}{c}8.35 \\
(8.27-8.42)\end{array}$ & $\begin{array}{c}21.0 \\
(20.2-21.6)\end{array}$ & $\begin{array}{c}0.295 \\
(0.277-0.354)\end{array}$ & & \\
\hline 53 & $\begin{array}{c}8.87 \\
(8.65-9.00)\end{array}$ & $\begin{array}{c}8.32 \\
(8.24-8.42)\end{array}$ & $\begin{array}{c}21.0 \\
(20.3-21.6)\end{array}$ & $\begin{array}{c}0.298 \\
(0.273-0.358)\end{array}$ & $\begin{array}{c}65 \\
(64-66)\end{array}$ & $\begin{array}{c}77 \\
(74-80)\end{array}$ \\
\hline
\end{tabular}

Summary of water quality parameters measured on 24-hour old solutions for the $D$. ambigua copper sulfate chronic test.: Values are expressed as means, ranges are presented in parentheses, $N=10$.

\begin{tabular}{|c|c|c|c|}
\hline $\begin{array}{c}\text { Conoentration } \\
(\mu \mathrm{g} / \mathrm{L})\end{array}$ & $\begin{array}{c}\text { Dissolved } \\
\text { Oxygen } \\
(\mathrm{mg} / \mathrm{L})\end{array}$ & $\mathrm{pH}$ & $\begin{array}{c}\text { Temperature } \\
(-\mathrm{C})\end{array}$ \\
\hline Control & $\begin{array}{c}9.02 \\
(8.81-9.25)\end{array}$ & $\begin{array}{c}8.36 \\
(8.27-8.43)\end{array}$ & $\begin{array}{c}21.0 \\
(20.4-21.6)\end{array}$ \\
\hline 19 & $\begin{array}{c}9.09 \\
(8.85-9.37)\end{array}$ & $\begin{array}{c}8.34 \\
(8.23-8.45)\end{array}$ & $\begin{array}{c}20.8 \\
(19.4-21.4)\end{array}$ \\
\hline 27 & $\begin{array}{c}9.14 \\
(8.97-9.45)\end{array}$ & $\begin{array}{c}8.35 \\
(8.27-8.42)\end{array}$ & $\begin{array}{c}20.8 \\
(19.6-21.6)\end{array}$ \\
\hline 33 & $\begin{array}{c}9.03 \\
(8.76-9.45)\end{array}$ & $\begin{array}{c}8.31 \\
(8.22-8.39)\end{array}$ & $\begin{array}{c}20.7 \\
(19.6-21.4)\end{array}$ \\
\hline 39 & $\begin{array}{c}9.08 \\
(8.79-9.52)\end{array}$ & $\begin{array}{c}8.32 \\
(8.22-8.41)\end{array}$ & $\begin{array}{c}20.7 \\
(19.5-21.4)\end{array}$ \\
\hline 49 & $\begin{array}{c}9.07 \\
(8.76-9.52)\end{array}$ & $\begin{array}{c}8.35 \\
(8.20-8.42)\end{array}$ & $\begin{array}{c}20.7 \\
(20.1-21.5)\end{array}$ \\
\hline 53 & $\begin{array}{c}8.94 \\
(8.12-9.48)\end{array}$ & $\begin{array}{c}8.35 \\
(8.20-8.42)\end{array}$ & $\begin{array}{c}20.7 \\
(20.1-21.4)\end{array}$ \\
\hline
\end{tabular}


APPENDIX 3

STREAM WATER TEST DATA:

D. ambigua AND C. dubia EXPOSED TO

1. UNALTERED STREAM WATER

2. STREAM WATER SPIKED WTTH SODIUM CHLORIDE 
APPENDIX 3 A

STREAM WATER TEST DATA:

C. dubia EXPOSED TO UNALTERED STREAM WATER 


\section{3-BROOD CHRONIC TOXICITY TEST WITH CERIODAPHNIA}

Survival and Reproduction Data

Toxicant: Unaltered laboratory and stream water

Test Initiation Date: $\quad 8-23-97$

\begin{tabular}{|c|c|c|c|c|c|}
\hline \multicolumn{6}{|c|}{ Reproduction in laboratory reconstituted water } \\
\hline Rep. & Day $3 / 4$ & Day 5 & Day 6 & Day 7 & Total \\
\hline 1 & 7 & 12 & 18 & 0 & 37 \\
\hline 2 & 6 & 11 & 16 & 0 & 33 \\
\hline 3 & 6 & 12 & 0 & 18 & 36 \\
\hline 4 & 3 & 12 & 0 & 17 & 32 \\
\hline 5 & 5 & 9 & 0 & 13 & 27 \\
\hline 6 & 7 & 10 & 0 & 17 & 34 \\
\hline 7 & 6 & 8 & 15 & 0 & 29 \\
\hline 8 & 6 & 10 & 0 & 17 & 33 \\
\hline 9 & 6 & 10 & 0 & 17 & 33 \\
\hline 10 & 6 & 12 & 0 & 17 & 35 \\
\hline 11 & 5 & 11 & $\mathbf{0}$ & 16 & 32 \\
\hline 12 & 6 & 8 & 9 & $\mathbf{0}$ & 23 \\
\hline 13 & 6 & 9 & 16 & 0 & 31 \\
\hline 14 & 7 & 10 & 18 & 0 & 35 \\
\hline 15 & 6 & 10 & 0 & 16 & 32 \\
\hline 16 & 5 & 9 & 0 & 17 & 31 \\
\hline 17 & 6 & 9 & 16 & 0 & 31 \\
\hline 18 & 5 & 10 & 0 & 16 & 31 \\
\hline 19 & 6 & 12 & 0 & 16 & 34 \\
\hline 20 & 6 & 13 & 16 & 0 & 35 \\
\hline \multicolumn{5}{|c|}{ Mean number of young per female } & 32.2 \\
\hline
\end{tabular}

\begin{tabular}{|c|c|c|c|c|c|}
\hline \multicolumn{6}{|c|}{ Reproduction in Pen Branch Water } \\
\hline Rep. & Day $3 / 4$ & Day 5 & Day 6 & Day 7 & Total \\
\hline 1 & 5 & 8 & 14 & 0 & 27 \\
\hline 2 & 6 & 10 & o & 18 & 34 \\
\hline 3 & 5 & 13 & 0 & 16 & 34 \\
\hline 4 & 5 & 13 & 16 & 0 & 34 \\
\hline 5 & 6 & 10 & 16 & 0 & 32 \\
\hline 6 & 6 & 10 & 11 & 0 & 27 \\
\hline 7 & 5 & 11 & 0 & 17 & 33 \\
\hline 8 & 6 & 10 & 9 & 7 & 32 \\
\hline 9 & 7 & 12 & 0 & 17 & 36 \\
\hline 10 & 7 & 9) & 14 & 0 & 30 \\
\hline 11 & 6 & 12 & 18 & 0 & 36 \\
\hline 12 & 6 & 11 & 14 & 0 & 31 \\
\hline 13 & 16 & 1 & 17 & 0 & 34 \\
\hline 14 & 6 & 9 & 16 & 0 & 31 \\
\hline 15 & 6 & 12 & 18 & 0 & 36 \\
\hline 16 & 5 & 12 & 15 & 0 & 32 \\
\hline 17. & 13 & 3 & 15 & 0 & 31 \\
\hline 18 & 6 & 10 & 16 & 0 & 32 \\
\hline 19 & 6 & 11 & 17 & 0 & 34 \\
\hline 20 & 2 & 11) & 19 & 0 & 32 \\
\hline Mea & ung & nale & & & 32.4 \\
\hline
\end{tabular}

\begin{tabular}{|c|c|c|c|c|c|}
\hline \multicolumn{6}{|c|}{ Reproduction in Four Mile Branch Water } \\
\hline Rep. & Day $3 / 4$ & Day 5 & Day 6 & Day 7 & Total \\
\hline 1 & 3 & 0 & 6 & 5 & 14 \\
\hline 2 & 1 & 0 & 5 & 8 & 14 \\
\hline 3 & 1) & 0 & 6 & 6 & 13 \\
\hline 4 & 1 & 0 & 5 & 6 & 12 \\
\hline 5 & 0] & 2 & 6 & 0 & 8 \\
\hline 6 & 3 & 0 & 4 & 7 & 14 \\
\hline 7 & 0) & 2 & 6 & 0 & 8 \\
\hline 8 & 0 & 2 & 0 & 5 & 7 \\
\hline 9 & 0] & 4 & 0 & 6 & 10 \\
\hline 10 & 2 & 6 & of & 6 & 14 \\
\hline 11) & 2 & 0 & 4 & 0 & 6 \\
\hline 12) & 3 & 4 & 0 & 6 & 13 \\
\hline 13 & 2 & 0 & 6 & 0 & 8 \\
\hline 14 & o) & 0 & 6 & 0 & 6 \\
\hline 15 & $2 \mid$ & 0 & 4 & 0 & 6 \\
\hline 16) & 2 & $\mathbf{0}$ & 6 & 0 & 8 \\
\hline 17. & 2 & 0 & 5 & 6 & 13 \\
\hline 18 & 0 & 2 & 6 & 0 & 8 \\
\hline 19 & 0 & 3 & 6 & 0 & 9 \\
\hline 20 & 이 & 2 & 3 & 0 & 5 \\
\hline \multicolumn{5}{|c|}{ Mean number of young per female } & 9.8 \\
\hline
\end{tabular}

\begin{tabular}{|r|r|r|r|r|r|}
\hline Reproduction in Upper Three Runs Water & \\
\hline Rep. & Day 3/4 & Day 5 & Day 6 & Day 7 & Total \\
\hline 1 & 7 & 10 & 0 & 13 & 30 \\
\hline 2 & 4 & 7 & 0 & 9 & 20 \\
\hline 3 & 5 & 14 & 0 & 10 & 29 \\
\hline 4 & 5 & 10 & 0 & 12 & 27 \\
\hline 5 & 6 & 9 & 11 & 0 & 26 \\
\hline 6 & 5 & 5 & $X$ & $X$ & 10 \\
\hline 7 & 6 & 7 & 10 & 0 & 23 \\
\hline 8 & 4 & 9 & 0 & 8 & 21 \\
\hline 9 & 6 & 10 & 11 & 0 & 27 \\
\hline 10 & 5 & 8 & 0 & 10 & 23 \\
\hline 11 & 5 & 6 & 0 & 8 & 19 \\
\hline 12 & 5 & 10 & 0 & 8 & 23 \\
\hline 13 & 4 & 12 & 0 & 10 & 26 \\
\hline 14 & 5 & 8 & 0 & 9 & 22 \\
\hline 15 & 6 & 10 & 0 & 12 & 28 \\
\hline 16 & 6 & 9 & $\times$ & $\times$ & 15 \\
\hline 17 & 5 & 11 & 12 & 0 & 28 \\
\hline 18 & 5 & 11 & 16 & 0 & 32 \\
\hline 19 & 6 & 10 & 16 & 0 & 32 \\
\hline 20 & 6 & 10 & 0 & 10 & 26 \\
\hline Mean number of young per female & & & 24.35 \\
\hline
\end{tabular}

$\mathrm{X}$ denotes death of test organism 
APPENDIX 3 A

Summary of statistical data from the chronic $C$. dubia test in unaltered stream water

\begin{tabular}{ccccccccc}
\hline & & \multicolumn{7}{c}{ Reproduction } \\
\cline { 5 - 8 } Group & Identification & N & Min & Max & Mean & Variance & SD & CV \% \\
\hline 1 & lab water & 20 & 23 & 37 & 32.20 & 10.379 & 3.222 & 10.01 \\
2 & Pen Branch & 20 & 27 & 36 & 32.40 & 6.463 & 2.542 & 7.85 \\
3 & Four Mile & 20 & 5 & 14 & 9.80 & 10.379 & 3.222 & 32.87 \\
4 & Upper Three Runs & 20 & 10 & 32 & 24.35 & 30.661 & 5.537 & 22.74 \\
\hline
\end{tabular}




\section{APPENDIX 3 A}

Summary of statistical analyses performed on data from the chronic C. dubia test with unaltered stream water.

CHI-SQUARE TEST FOR NORMALITY: ACTUAL AND EXPECTED FREQUENCIES

\begin{tabular}{llllll}
\hline INTERVAL & $<-1.5$ & -1.5 to $<-0.5$ & -0.5 to 0.5 & $>0.5$ to 1.5 & $>1.5$ \\
\hline EXPECTED & 5.360 & 19.360 & 30.560 & 19.360 & 5.360 \\
OBSERVED & 6 & 18 & 27 & 29 & 0 \\
\hline
\end{tabular}

Calculated Chi-Square goodness of fit test statistic $=10.7467$

Table Chi-Square value $($ alpha $=0.01)=13.277$

Data PASS normality test. Continue analysis.

\section{BARTLETT'S TEST FOR HOMOGENEITY OF VARIANCE}

Calculated B1 statistic $=13.38$

Table Chi-square value $=11.34($ alpha $=0.01, \mathrm{df}=3)$

Table Chi-square value $=7.81($ alpha $=0.05, \mathrm{df}=3)$

Data FAIL B1 homogeneity test at 0.01 level.

\begin{tabular}{ccccccc}
\multicolumn{2}{l}{ STEEL'S MANY-ONE RANK TEST } & Ho:Control< Treatment & \\
\hline Group & Identification & Mean & $\begin{array}{c}\text { Rank } \\
\text { Sum }\end{array}$ & $\begin{array}{c}\text { Critical } \\
\text { Value }\end{array}$ & df & Significant \\
\hline 1 & Control & 32.20 & & & & \\
2 & Pen Branch & 32.40 & 410.50 & 333.00 & 20 & \\
3 & Four Mile & 9.80 & 210.00 & 333.00 & 20 & $*$ \\
4 & Upper Three Runs & 24.35 & 244.00 & 333.00 & 20 & $*$ \\
\hline
\end{tabular}

Critical values use $k=5$, are 1 talled, and alpha $=0.05$ 
APPENDIX 3 B

STREAM WATER TEST DATA:

D. ambigua EXPOSED TO UNALTERED STREAM WATER 


\section{3-BROOD CHRONIC TOXICITY TEST WITH DAPHNIA AMBIGUA \\ Survival and Reproduction Data}

Toxicant: Unaltered laboratory and stream water

Test Initiation Date: 8-23-97

\begin{tabular}{|c|c|c|c|c|c|c|}
\hline \multicolumn{7}{|c|}{ Reproduction in laboratory reconstituted water } \\
\hline Rep. & Day $5 / 6$ & Day 7 & Day 8 & Day 9 & Day 10 & Total \\
\hline 1 & 7 & 0 & 0 & 12 & 0 & 19 \\
\hline 2 & 5 & 0 & 0 & 10 & 8 & 23 \\
\hline 3 & 4 & 0 & 0 & 10 & 10 & 24 \\
\hline 4 & 3 & of & o & 11 & 0 & 14 \\
\hline 5 & 8 & 0 & o & 12 & 5 & 25 \\
\hline 6 & 6 & 0 & of & 9 & 0 & 15 \\
\hline 7 & 5 & 0 & 0 & 8 & 0 & 13 \\
\hline 8 & 2 & o) & 0 & 9 & $\mathbf{0}$ & 11 \\
\hline 9 & 2 & 0 & 0 & 10 & 8 & 20 \\
\hline 10 & 8 & 0 & 0 & 11 & $\mathbf{0}$ & 19 \\
\hline 11 & 8 & o & o) & 15) & 0 & 23 \\
\hline 12 & 8 & 0 & 0 & 9 & 0 & 17 \\
\hline 13 & 3 & 0 & o) & 12 & $\mathbf{0}$ & 15 \\
\hline 14 & 5 & 0 & 0 & 9 & 8 & 22 \\
\hline 15 & 4 & 0 & 0 & 10 & 0 & 14 \\
\hline 16 & 6 & 0 & 0 & 12 & 5 & 23 \\
\hline 17 & 7 & 0 & 0 & 11 & 0 & 18 \\
\hline 18 & 5 & o) & 0 & 11 & 0 & 16 \\
\hline 19 & 5 & 0 & 0 & 6 & 10 & 21 \\
\hline 20 & 4 & 0 & 0 & 10 & 0 & 14 \\
\hline \multicolumn{6}{|c|}{ Mean number of young per female } & 18.3 \\
\hline
\end{tabular}

\begin{tabular}{|c|c|c|c|c|c|c|}
\hline \multicolumn{4}{|c|}{ Reproduction in Pen Branch Water } & \multirow[b]{2}{*}{ Day 9} & \multirow[b]{2}{*}{ Day 10} & \multirow[b]{2}{*}{ Total } \\
\hline Rep. & Day $5 / 6$ & Day 7 & Day 8 & & & \\
\hline 1 & 8 & 11 & 0 & 0 & 11 & 30 \\
\hline 2 & 7 & 0 & 0 & 10 & 5 & 22 \\
\hline 3 & 8 & 0 & 0 & 13 & 0 & 21 \\
\hline 4 & 11 & 0 & 0 & 14 & 15 & 40 \\
\hline 5 & 6 & 0 & 0 & 10 & 9 & 25 \\
\hline 6 & 6 & 0 & 0 & 10 & 10 & 26 \\
\hline 7 & 7 & 0 & 0 & 12 & 13 & 32 \\
\hline 8 & 10 & 0 & 0 & 13 & 0 & 23 \\
\hline 9 & 9 & 0 & 0 & 10 & 0 & 19 \\
\hline 10 & 9 & 0 & 0 & 10 & 0 & 19 \\
\hline 11 & 10 & 0 & 0 & 13 & 2 & 25 \\
\hline 12 & 5 & 0 & 0 & 10 & 9 & 24 \\
\hline 13 & 6 & 0 & 0 & 10 & 10 & 26 \\
\hline 14 & 6 & 0 & 0 & 13 & 0 & 19 \\
\hline 15 & 8 & 0 & 0 & 12 & 9 & 29 \\
\hline 16 & s) & 0 & 0 & 12 & 0 & 17 \\
\hline 17 & 7 & 0 & 0 & 11 & 13 & 31 \\
\hline 18 & 10 & 0 & 0 & 10 & 0 & 20 \\
\hline 19 & 10 & 0 & 0 & 9 & 10 & 29 \\
\hline 20 & 9| & 0 & 0 & 10 & 0 & 19 \\
\hline \multicolumn{6}{|c|}{ Mean number of young per female } & 24.8 \\
\hline
\end{tabular}

\begin{tabular}{|r|r|r|r|r|r|r|}
\hline Reproduction in Four Mile Branch Water \\
\hline Rep. & Day 5/6 & Day 7 & Day 8 & Day 9 & Day 10 & Total \\
\hline 1 & 5 & 0 & 0 & 13 & 12 & 30 \\
\hline 2 & 6 & 0 & 0 & 12 & 11 & 29 \\
\hline 3 & 5 & 0 & 0 & 12 & 11 & 28 \\
\hline 4 & 8 & 0 & 0 & 10 & 0 & 18 \\
\hline 5 & 7 & 0 & 0 & 13 & 12 & 32 \\
\hline 6 & 7 & 1 & 0 & 12 & 0 & 20 \\
\hline 7 & 6 & 0 & 0 & 14 & 0 & 20 \\
\hline 8 & 6 & 0 & 0 & 10 & 0 & 16 \\
\hline 9 & 9 & 0 & 0 & 15 & 0 & 24 \\
\hline 10 & 7 & 0 & 0 & 14 & 0 & 21 \\
\hline 11 & 5 & 0 & 0 & 10 & 12 & 27 \\
\hline 12 & 6 & 0 & 0 & 12 & 10 & 28 \\
\hline 13 & 7 & 0 & 0 & 13 & 0 & 20 \\
\hline 14 & 7 & 0 & 0 & 12 & 10 & 29 \\
\hline 15 & 8 & 0 & 0 & 10 & 0 & 18 \\
\hline 16 & 6 & 0 & 0 & 10 & 11 & 27 \\
\hline 17 & 5 & 0 & 0 & 11 & 0 & 16 \\
\hline 18 & 7 & 0 & 0 & 11 & 0 & 18 \\
\hline 19 & 8 & 0 & 0 & 12 & 11 & 31 \\
\hline 20 & 6 & 0 & 0 & 13 & 0 & 19 \\
\hline Mean number of young per female & & & 23.55 \\
\hline
\end{tabular}

\begin{tabular}{|r|r|r|r|r|r|r|}
\hline Reproduction in Upper Three Runs Water \\
\hline Rep. & Day 5/6 & Day 7 & Day 8 & Day 9 & Day 10 & Total \\
\hline 1 & 9 & 0 & 0 & 10 & 0 & 19 \\
\hline 2 & 5 & 0 & 0 & 13 & 15 & 33 \\
\hline 3 & 6 & 0 & 0 & 9 & 10 & 25 \\
\hline 4 & 6 & 0 & 0 & 10 & 10 & 26 \\
\hline 5 & 5 & 0 & 0 & 11 & 12 & 28 \\
\hline 6 & 6 & 0 & 0 & 9 & 8 & 23 \\
\hline 7 & 5 & 0 & 0 & 8 & 9 & 22 \\
\hline 8 & 6 & 0 & 0 & 13 & 10 & 29 \\
\hline 9 & 7 & 0 & 0 & 13 & 10 & 30 \\
\hline 10 & 9 & 0 & 0 & 12 & 10 & 31 \\
\hline 11 & 8 & 0 & 0 & 12 & 0 & 20 \\
\hline 12 & 9 & 0 & 0 & 13 & 8 & 30 \\
\hline 13 & 6 & 0 & 0 & 13 & 0 & 19 \\
\hline 14 & 6 & 0 & 0 & 13 & 0 & 19 \\
\hline 15 & 7 & 0 & 0 & 10 & 10 & 27 \\
\hline 16 & 7 & 0 & 0 & 12 & 0 & 19 \\
\hline 17 & 5 & 0 & 0 & 12 & 0 & 17 \\
\hline 18 & 8 & 0 & 0 & 10 & 0 & 18 \\
\hline 19 & 9 & 0 & 0 & 10 & 8 & 27 \\
\hline 20 & 7 & 0 & 0 & 10 & 11 & 28 \\
\hline Mean number of young per female & & & 24.5 \\
\hline
\end{tabular}

$\mathrm{X}$ denotes death of test organism 


\section{APPENDIX 3 B}

Summary of statistical data from the chronic $D$. ambigua test in unaltered stream water

\begin{tabular}{ccccccccc}
\hline \multirow{2}{*}{ Group } & \multirow{2}{*}{ Identification } & $\mathrm{N}$ & \multicolumn{7}{c}{ Reproduction } \\
\cline { 5 - 8 } & & & Min & Max & Mean & Variance & SD & CV \% \\
\hline 1 & lab water & 20 & 11 & 25 & 18.30 & 17.589 & 4.194 & 22.92 \\
2 & Pen Branch & 20 & 17 & 40 & 24.80 & 33.221 & 5.764 & 23.24 \\
3 & Four Mile & 20 & 16 & 32 & 23.55 & 29.629 & 5.443 & 23.11 \\
4 & Upper Three Runs & 20 & 17 & 33 & 24.50 & 25.421 & 5.042 & 20.58 \\
\hline
\end{tabular}




\begin{abstract}
APPENDIX 3 B
Summary of statistical analyses performed on data from the chronic $D$. ambigua test with unaltered stream water.
\end{abstract}

CHI-SQUARE TEST FOR NORMALITY: ACTUAL AND EXPECTED FREQUENCIES

\begin{tabular}{llllll}
\hline INTERVAL & $<-1.5$ & -1.5 to $<-0.5$ & -0.5 to 0.5 & $>0.5$ to 1.5 & $>1.5$ \\
\hline EXPECTED & 5.360 & 19.360 & 30.560 & 19.360 & 5.360 \\
OBSERVED & 1 & 30 & 20 & 25 & 4 \\
\hline
\end{tabular}

Calculated Chi-Square goodness of fit test statistic $=15.0313$

Table Chi-Square value $($ alpha $=0.01)=13.277$

Data FAIL normality test. No need to continue analysis.

\title{
BARTLETT'S TEST FOR HOMOGENEITY OF VARIANCE
}

Calculated B1 statistic $=2.02$

Table Chi-square value $=11.34($ alpha $=0.01, \mathrm{df}=3)$

Table Chi-square value $=7.81($ alpha $=0.05, \mathrm{df}=3)$

Data PASS B1 homogeneity test at 0.01 level.

\begin{tabular}{ccccccc} 
STEEL'S MANY-ONE RANK TEST & Ho:Control< Treatment & \\
\hline Group & Identification & Mean & $\begin{array}{c}\text { Rank } \\
\text { Sum }\end{array}$ & $\begin{array}{c}\text { Critical } \\
\text { Value }\end{array}$ & df & Significant \\
\hline 1 & Control & 18.30 & & & & \\
2 & Pen Branch & 24.80 & 537.00 & 333.00 & 20 & \\
3 & Four Mile & 23.55 & 514.00 & 333.00 & 20 & \\
4 & Upper Three Runs & 24.50 & 535.00 & 333.00 & 20 & \\
\hline
\end{tabular}

Critical values use $k=5$, are 1 tailed, and alpha $=0.05$ 
APPENDIX $3 \mathrm{C}$

STREAM WATER TEST DATA:

D. ambigua AND C. dubia EXPOSED TO

STREAM WATER SPIKED WITH SODIUM CHLORIDE 


\section{APPENDIX 3 C - ANALYTICAL CHEMISTRY DATA NaCI IN PEN BRANCH ACUTE}

Nominal and actual concentrations of sodium chloride in solutions used for acute toxicity testing. Actual concentrations of sodium were measured in the spiking solution, and final concentrations were calculated based on the amount of stock solutions spiked into the final dilution water. These values are applicable to the testing for both species. Values were determined by Trace Scan ICP.

\begin{tabular}{|c|c|c|c|c|}
\hline $\begin{array}{c}\text { Nominal NaC1 } \\
\text { Concentration } \\
\text { in the Test } \\
\begin{array}{c}\text { Solution } \\
(\mathrm{g} / \mathrm{L})\end{array}\end{array}$ & $\begin{array}{c}\text { NaC } \\
\text { Concentration } \\
\text { in the Spiking } \\
\text { Solution } \\
(\mathrm{g} / \mathrm{L})^{1}\end{array}$ & $\begin{array}{c}\text { Amount of } \\
\text { Spiking } \\
\text { Solution } \\
\text { Used } \\
(\mathrm{mL})\end{array}$ & $\begin{array}{c}\text { Final } \\
\text { Volume of } \\
\text { Test } \\
\text { Solution } \\
(\mathrm{mL})\end{array}$ & $\begin{array}{c}\text { Actual } \\
\text { Concentration } \\
\text { of NaCl in } \\
\text { Test Solution } \\
(\mathrm{g} / \mathrm{L})\end{array}$ \\
\hline 0.5 & 87.9 & 2.5 & 500 & 0.44 \\
\hline 1.0 & 87.9 & 5.0 & 500 & 0.88 \\
\hline 1.5 & 87.9 & 7.5 & 500 & 1.32 \\
\hline 2.0 & 87.9 & 10.0 & 500 & 1.76 \\
\hline 2.5 & 87.9 & 12.5 & 500 & 2.20 \\
\hline 3.0 & 87.9 & 15.0 & 500 & 2.64 \\
\hline
\end{tabular}

${ }^{1}$ The measured sodium concentration for the spiking solution in Pen Branch was $34.5 \mathrm{~g} / \mathrm{L}$. The sodium chloride concentration of $87.9 \mathrm{~g} / \mathrm{L}$ was calculated using the following formula: $[\mathrm{NaCl}]=([\mathrm{Na}] / 22.9) * 58.35$. 
APPENDIX 3 C

Forty-eight hour mortality observations on $C$. dubia in the Pen Branch sodium chloride toxicity test.

\begin{tabular}{|c|cc|cc|cc|}
\hline $\begin{array}{c}\text { Sodium Chloride } \\
\text { Concentration } \\
\text { (g/L) }\end{array}$ & \multicolumn{5}{|c|}{ Replicate } & \multicolumn{2}{c|}{ Total } \\
& \multicolumn{2}{|c|}{1 2 } & & \\
\cline { 2 - 8 } & dead alive & dead alive & dead & alive \\
\hline Control & 0 & 10 & 0 & 10 & 0 & 20 \\
\hline 0.44 & 0 & 10 & 0 & 10 & 0 & 20 \\
\hline 0.88 & 0 & 10 & 0 & 10 & 0 & 20 \\
\hline 1.32 & 0 & 10 & 1 & 9 & 1 & 19 \\
\hline 1.76 & 9 & 1 & 9 & 1 & 18 & 2 \\
\hline 2.20 & 10 & 0 & 10 & 0 & 20 & 0 \\
\hline 2.64 & 10 & 0 & 10 & 0 & 20 & 0 \\
\hline
\end{tabular}

48-hour $\mathrm{LC}_{50}=1.54 \mathrm{~g} / \mathrm{L}(95 \%$ confidence limits $=1.47-1.61 \mathrm{~g} / \mathrm{L})$.

Forty-eight hour mortality observations on $D$. ambigua in the Pen Branch sodium chloride toxicity test.

\begin{tabular}{|c|cc|cc|cc|}
\hline $\begin{array}{c}\text { Sodium Chloride } \\
\begin{array}{c}\text { Concentration } \\
(\mathrm{g} / \mathrm{L})\end{array}\end{array}$ & \multicolumn{4}{|c|}{ Replicate } & \multicolumn{2}{c|}{ Total } \\
\cline { 2 - 8 } & \multicolumn{2}{|c|}{1} & \multicolumn{2}{c|}{2} & & \\
& dead alive & dead alive & dead & alive \\
\hline Control & 0 & 10 & 0 & 10 & 0 & 20 \\
\hline 0.44 & 0 & 10 & 0 & 10 & 0 & 20 \\
\hline 0.88 & 0 & 10 & 0 & 10 & 0 & 20 \\
\hline 1.32 & 2 & 8 & 3 & 7 & 5 & 15 \\
\hline 1.76 & 10 & 0 & 10 & 0 & 20 & 0 \\
\hline 2.20 & 10 & 0 & 10 & 0 & 20 & 0 \\
\hline 2.64 & 10 & 0 & 10 & 0 & 20 & 0 \\
\hline
\end{tabular}

48-hour $\mathrm{LC}_{50}=1.40 \mathrm{~g} / \mathrm{L}(95 \%$ confidence limits $=1.31-1.50 \mathrm{~g} / \mathrm{L})$. 
Summary of statistical analysis for the $C$. dubia 48-hour acute test with sodium chloride in water collected from Pen Branch.

\section{CT-TOX MULTI-METHOD PROGRAM \\ Binomial, Moving average, Probit, and Spearman-Karber Methods}

TEST SUMMARY

DATE: 8-29-97

DURATION: 48 hours

SAMPLE: $\mathrm{NaCl}$ in Pen Branch SPECIES: Ceriodaphnia dubia

\begin{tabular}{|l|c|c|c|c|}
\hline \multirow{2}{*}{ METHOD } & \multirow{2}{*}{ LC50 } & \multicolumn{3}{c|}{ CONFIDENCE LIMITS } \\
\cline { 3 - 5 } & & LOWER & UPPER & SPAN \\
\hline Binomial & 1.544 & 1.320 & 1.760 & 0.440 \\
\hline MAA & $* * * *$ & $* * * *$ & $* * * *$ & $* * * *$ \\
\hline Probit & $* * * *$ & $* * * *$ & $* * * *$ & $* * * *$ \\
\hline Spearman-Karber & 1.537 & 1.465 & 1.613 & 0.148 \\
\hline
\end{tabular}

**** $=$ Limit does not exist.

TRIMMED SPEARMAN-KARBER SUMMARY

Trim:

$0 \%$

LC50:

95\% Lower confidence: $\quad 1.465$

95\% Upper confidence: $\quad 1.613$

BINOMIAL METHOD

\begin{tabular}{|c|c|c|c|l|}
\hline $\begin{array}{c}\text { Concentration } \\
(\mathrm{g} / \mathrm{L})\end{array}$ & $\begin{array}{c}\text { Number } \\
\text { Exposed }\end{array}$ & $\begin{array}{c}\text { Number } \\
\text { Dead }\end{array}$ & $\begin{array}{c}\text { Percent } \\
\text { Dead }\end{array}$ & $\begin{array}{c}\text { Binomial } \\
\text { Probability (\%) }\end{array}$ \\
\hline 0.44 & 20 & 0 & 0 & $.9537 \mathrm{D}-04$ \\
\hline 0.88 & 20 & 0 & 0 & $.9537 \mathrm{D}-04$ \\
\hline 1.32 & 20 & 1 & 5 & $.2003 \mathrm{D}-02$ \\
\hline 1.76 & 20 & 18 & 90 & $.2012 \mathrm{D}-01$ \\
\hline 2.20 & 20 & 20 & 100 & $.9537 \mathrm{D}-04$ \\
\hline 2.64 & 20 & 20 & 100 & $.9537 \mathrm{D}-04$ \\
\hline
\end{tabular}

The binomial test shows that 1.32 and 1.76 can be statistically sound conservative 95 percent confidence limits since the actual confidence level associated with these limits is 99.9779 percent. An approximate LC50 for this data set is $\mathbf{1 . 5 4 4 .}$ 


\section{RESULTS USING MOVING AVERAGE}

The moving average method cannot be used with this data set because no span which produces average angles bracketing 45 degrees also uses two percent dead between 0 and 100 percent.

\section{RESULTS CALCULATED BY PROBIT METHOD}

No convergence in 25 iterations. Probit method probably can not be use with this set of data. 
Summary of statistical analysis for the $D$. ambigua 48-hour acute test with sodium chloride in water collected from Pen Branch.

\section{CT-TOX MULTI-METHOD PROGRAM \\ Binomial, Moving average, Probit, and Spearman-Karber Methods}

TEST SUMMARY

DATE: 8-29-97

DURATION: 48 hours

SAMPLE:NaCl in Pen Branch SPECIES: Daphnia ambigua

\begin{tabular}{|l|c|c|c|c|}
\hline \multirow{2}{*}{ METHOD } & \multirow{2}{*}{ LC50 } & \multicolumn{3}{c|}{ CONFIDENCE LIMITS } \\
\cline { 3 - 5 } & & LOWER & UPPER & SPAN \\
\hline Binomial & 1.426 & 1.320 & 1.760 & 0.440 \\
\hline MAA & $* * * *$ & $* * * *$ & $* * * *$ & $* * * *$ \\
\hline Probit & $* * * *$ & $* * * *$ & $* * * *$ & $* * * *$ \\
\hline Spearman-Karber & 1.398 & 1.307 & 1.495 & 0.188 \\
\hline
\end{tabular}

**** = Limit does not exist.

TRIMMED SPEARMAN-KARBER SUMMARY

Trim:

$0 \%$

LC50: $\quad 1.398$

95\% Lower confidence: $\quad 1.307$

95\% Upper confidence: $\quad 1.495$

\section{BINOMIAL METHOD}

\begin{tabular}{|c|c|c|c|l|}
\hline $\begin{array}{c}\text { Concentration } \\
(\mathrm{g} / \mathrm{L})\end{array}$ & $\begin{array}{c}\text { Number } \\
\text { Exposed }\end{array}$ & $\begin{array}{c}\text { Number } \\
\text { Dead }\end{array}$ & $\begin{array}{c}\text { Percent } \\
\text { Dead }\end{array}$ & $\begin{array}{c}\text { Binomial } \\
\text { Probability (\%) }\end{array}$ \\
\hline 0.44 & 20 & 0 & 0 & $.9537 \mathrm{D}-04$ \\
\hline 0.88 & 20 & 0 & 0 & $.9537 \mathrm{D}-04$ \\
\hline 1.32 & 20 & 5 & 25 & $.2069 \mathrm{D}+01$ \\
\hline 1.76 & 20 & 20 & 100 & $.9537 \mathrm{D}-04$ \\
\hline 2.20 & 20 & 20 & 100 & $.9537 \mathrm{D}-04$ \\
\hline 2.64 & 20 & 20 & 100 & $.9537 \mathrm{D}-04$ \\
\hline
\end{tabular}

The binomial test shows that 1.32 and 1.76 can be statistically sound conservative 95 percent confidence limits since the actual confidence level associated with these limits is 97.9304 percent. An approximate LC50 for this data set is $\mathbf{1 . 4 2 6 .}$ 
WHEN THERE ARE LESS THAN TWO CONCENTRATIONS AT WHICH THE PERCENT DEAD IS BETWEEN 0 AND 100, NEITHER THE MOVING AVERAGE NOR THE PROBIT METHOD CAN GIVE ANY STATISTICALLY SOUND RESULTS. 
TEST: $\quad$ Sodium chloride test in Pen Branch water for $C$ dubia

Start Date: $\quad 8 / 29 / 97$

Initial Water Chemistry

\begin{tabular}{ccccccc}
\hline $\begin{array}{c}\text { Concentration } \\
(\mathrm{g} / \mathrm{L})\end{array}$ & $\begin{array}{c}\mathrm{DO} \\
(\mathrm{mg} / \mathrm{L})\end{array}$ & $\mathrm{pH}$ & $\begin{array}{c}\text { Temperature } \\
\left({ }^{\circ} \mathrm{C}\right)\end{array}$ & $\begin{array}{c}\text { Conductivity } \\
(\mathrm{ms} / \mathrm{cm})\end{array}$ & $\begin{array}{c}\text { Alkalinity } \\
\left(\mathrm{mg} / \mathrm{L} \text { as } \mathrm{CaCO}_{3}\right)\end{array}$ & $\begin{array}{c}\text { Hardness } \\
\left(\mathrm{mg} / \mathrm{L} \text { as } \mathrm{CaCO}_{3}\right)\end{array}$ \\
\hline Control & 8.39 & 7.70 & 24.4 & 0.050 & 26 & 18 \\
0.44 & 8.45 & 7.69 & 24.0 & 1.000 & & \\
0.88 & 8.63 & 7.68 & 24.5 & 1.930 & & \\
1.32 & 8.39 & 7.63 & 24.1 & 2.790 & & \\
1.76 & 8.54 & 7.66 & 24.2 & 3.680 & & 18 \\
2.2 & 8.24 & 7.71 & 24.2 & 4.750 & & \\
2.64 & 8.36 & 7.66 & 24.2 & 5.540 & & \\
\hline
\end{tabular}

24-Hour Readings

\begin{tabular}{cccc}
\hline $\begin{array}{c}\text { Concentration } \\
(\mathrm{g} / \mathrm{L})\end{array}$ & $\begin{array}{c}\text { DO } \\
(\mathrm{m} \mathrm{g} / \mathrm{L})\end{array}$ & pH & $\begin{array}{c}\text { Temperature } \\
\left({ }^{\circ} \mathrm{C}\right)\end{array}$ \\
\hline Control & 8.36 & 7.65 & 24.0 \\
0.44 & 8.44 & 7.71 & 24.0 \\
0.88 & 8.45 & 7.70 & 24.1 \\
1.32 & 7.49 & 7.69 & 24.5 \\
1.76 & 8.35 & 7.68 & 24.5 \\
2.2 & 8.39 & 7.70 & 24.2 \\
2.64 & 8.37 & 7.71 & 24.3 \\
\hline
\end{tabular}

48-Hour Readings

\begin{tabular}{cccc}
\hline $\begin{array}{c}\text { Concentration } \\
(\mathrm{g} / \mathrm{L})\end{array}$ & $\begin{array}{c}\text { DO } \\
(\mathbf{m g} / \mathbf{L})\end{array}$ & $\mathbf{p H}$ & $\begin{array}{c}\text { Temperature } \\
\left({ }^{\circ} \mathrm{C}\right)\end{array}$ \\
\hline Control & $\mathbf{8 . 4 4}$ & 7.62 & 24.5 \\
0.44 & 8.47 & 7.65 & 24.4 \\
0.88 & 8.50 & 7.69 & 24.4 \\
1.32 & 8.22 & 7.68 & 24.2 \\
1.76 & 8.47 & 7.68 & 24.4 \\
2.2 & 8.05 & 7.67 & 24.6 \\
2.64 & 8.33 & 7.65 & 24.2 \\
\hline
\end{tabular}


TEST: $\quad$ Sodium chloride test in Pen Branch water for D. ambigua

Start Date: $\quad 8 / 29 / 97$

Initial Water Chemistry

\begin{tabular}{|c|c|c|c|c|c|c|}
\hline $\begin{array}{c}\text { Concentration } \\
(\mathrm{g} / \mathrm{L})\end{array}$ & $\begin{array}{c}\mathrm{DO} \\
(\mathrm{mg} / \mathrm{L})\end{array}$ & pH & $\begin{array}{c}\text { Temperature } \\
\left({ }^{\circ} \mathrm{C}\right)\end{array}$ & $\begin{array}{c}\text { Conductivity } \\
\text { (ms/cm) }\end{array}$ & $\begin{array}{c}\text { Alkalinity } \\
\left(\mathrm{mg} / \mathrm{L} \text { as } \mathrm{CaCO}_{3}\right)\end{array}$ & $\begin{array}{c}\text { Hardness } \\
\left.\text { (mg/L as } \mathrm{CaCO}_{3}\right)\end{array}$ \\
\hline Control & 8.63 & 7.74 & 21.2 & 0.050 & 26 & 18 \\
\hline 0.44 & 8.56 & 7.72 & 21.1 & 1.000 & & \\
\hline 0.88 & 8.44 & 7.68 & 21.4 & 1.930 & & \\
\hline 1.32 & 8.39 & 7.71 & 21.5 & 2.790 & & \\
\hline 1.76 & 8.55 & 7.70 & 21.1 & 3.680 & & \\
\hline 2.2 & 8.21 & 7.73 & 21.2 & 4.750 & & \\
\hline 2.64 & 8.34 & 7.77 & 21.3 & 5.540 & 24 & 20 \\
\hline
\end{tabular}

24-Hour Readings

\begin{tabular}{cccc}
\hline $\begin{array}{c}\text { Concentration } \\
(\mathrm{g} / \mathrm{L})\end{array}$ & $\begin{array}{c}\text { DO } \\
(\mathbf{m g} / \mathrm{L})\end{array}$ & pH & $\begin{array}{c}\text { Temperature } \\
\left({ }^{\circ} \mathrm{C}\right)\end{array}$ \\
\hline Control & 7.90 & 7.56 & 21.7 \\
0.44 & 8.31 & 7.58 & 21.5 \\
0.88 & 8.13 & 7.53 & 21.4 \\
1.32 & 8.14 & 7.54 & 21.5 \\
1.76 & 8.04 & 7.53 & 21.7 \\
2.2 & 8.33 & 7.54 & 21.8 \\
2.64 & 7.88 & 7.55 & 21.7 \\
\hline
\end{tabular}

48-Hour Readings

\begin{tabular}{cccc}
\hline $\begin{array}{c}\text { Concentration } \\
(\mathrm{g} / \mathrm{L})\end{array}$ & $\begin{array}{c}\text { DO } \\
(\mathbf{m g} / \mathrm{L})\end{array}$ & pH & $\begin{array}{c}\text { Temperature } \\
\left({ }^{\circ} \mathrm{C}\right)\end{array}$ \\
\hline Control & 8.77 & 7.92 & 20.2 \\
0.44 & 9.03 & 7.81 & 19.7 \\
0.88 & 9.09 & 7.82 & 19.3 \\
1.32 & 9.45 & 7.82 & 19.3 \\
1.76 & 9.32 & 7.75 & 19.5 \\
2.2 & 9.06 & 7.76 & 19.8 \\
2.64 & 9.19 & 7.74 & 19.6 \\
\hline
\end{tabular}




\section{APPENDIX 3 C - ANALYTICAL CHEMISTRY DATA NaCI IN UPPER THREE RUNS ACUTE}

Nominal and actual concentrations of sodium chloride in solutions used for acute toxicity testing. Actual concentrations of sodium were measured in the spiking solution, and final concentrations were calculated based on the amount of stock solutions spiked into the final dilution water. These values are applicable to the testing for both species. Values were determined by Trace Scan ICP.

\begin{tabular}{|c|c|c|c|c|}
\hline $\begin{array}{c}\text { Nominal NaCI } \\
\text { Concentration } \\
\text { in the Test } \\
\text { Solution } \\
(\mathrm{g} / \mathrm{L})\end{array}$ & $\begin{array}{c}\text { NaCI } \\
\text { Concentration } \\
\text { in the Spiking } \\
\text { Solution } \\
(\mathrm{g} / \mathrm{L})^{1}\end{array}$ & $\begin{array}{c}\text { Amount of } \\
\text { Spiking } \\
\text { Solution } \\
\text { Used } \\
(\mathrm{mL})\end{array}$ & $\begin{array}{c}\text { Final } \\
\text { Volume of } \\
\text { Test } \\
\text { Solution } \\
(\mathrm{mL})\end{array}$ & $\begin{array}{c}\text { Actual } \\
\text { Concentration } \\
\text { of NaC in } \\
\text { Test Solution } \\
(\mathrm{g} / \mathrm{L})\end{array}$ \\
\hline 0.0625 & 87.9 & 0.312 & 500 & 0.05 \\
\hline 0.125 & 87.9 & 0.625 & 500 & 0.11 \\
\hline 0.25 & 87.9 & 1.25 & 500 & 0.22 \\
\hline 0.5 & 87.9 & 2.5 & 500 & 0.44 \\
\hline 1.0 & 87.9 & 5.0 & 500 & 0.88 \\
\hline 1.5 & 87.9 & 7.5 & 500 & 1.32 \\
\hline
\end{tabular}

${ }^{1}$ The measured sodium concentration for the spiking solution in Upper Three Runs was $34.5 \mathrm{~g} / \mathrm{L}$. The sodium chloride concentration of $87.9 \mathrm{~g} / \mathrm{L}$ was calculated using the following formula: $[\mathrm{NaCl}]=([\mathrm{Na}] / 22.9) * 58.35$. 
Forty-eight hour mortality observations on $C$. dubia in the Upper Three Runs sodium chloride toxicity test.

\begin{tabular}{|c|c|c|c|c|}
\hline \multirow{2}{*}{$\begin{array}{c}\text { Sodium Chloride } \\
\text { Concentration } \\
(\mathrm{g} / \mathrm{L})\end{array}$} & \multicolumn{2}{|c|}{ Replicate } & \multicolumn{2}{|c|}{ Total } \\
\hline & dead alive & $\frac{2}{\text { dead alive }}$ & dead & alive \\
\hline Control & 0 & 0 & 0 & 20 \\
\hline 0.05 & 10 & 10 & 0 & 20 \\
\hline 0.11 & 9 & 2 & 3 & 17 \\
\hline 0.22 & 10 & 8 & 18 & 2 \\
\hline 0.44 & 10 & 10 & 20 & $\overline{0}$ \\
\hline 0.88 & 10 & 10 & 20 & 0 \\
\hline 1.32 & 10 & 10 & 20 & 0 \\
\hline
\end{tabular}

48-hour $\mathrm{LC}_{50}=0.15 \mathrm{~g} / \mathrm{L}(95 \%$ confidence limits $=0.13-0.17 \mathrm{~g} / \mathrm{L})$

Forty-eight hour mortality observations on $D$. ambigua in the Upper Three Runs sodium chloride toxicity test.

\begin{tabular}{|c|c|c|c|c|}
\hline \multirow{2}{*}{$\begin{array}{l}\text { Sodium Chloride } \\
\text { Concentration } \\
\text { (g/L) }\end{array}$} & \multicolumn{2}{|c|}{ Replicate } & \multicolumn{2}{|c|}{ Total } \\
\hline & dead alive & dead alive & dead & alive \\
\hline Control & $\begin{array}{ll}0 & 10\end{array}$ & 0 & 0 & 20 \\
\hline 0.05 & 10 & 10 & 0 & 20 \\
\hline$\overline{0.11}$ & 10 & 10 & 0 & 20 \\
\hline 0.22 & 10 & 10 & 0 & 20 \\
\hline 0.44 & 10 & 8 & 2 & 18 \\
\hline 0.88 & 10 & 10 & 20 & 0 \\
\hline 1.32 & 10 & 10 & 20 & 0 \\
\hline
\end{tabular}

48-hour $\mathrm{LC}_{50}=0.58 \mathrm{~g} / \mathrm{L}(95 \%$ confidence limits $=0.53-0.64 \mathrm{~g} / \mathrm{L})$. 
Summary of statistical analysis for the $C$. dubia 48-hour acute test with sodium chloride in water collected from Upper Three Runs.

\section{CT-TOX MULTI-METHOD PROGRAM}

Binomial, Moving average, Probit, and Spearman-Karber Methods

\section{TEST SUMMARY}

DATE: 9-1-97

DURATION: 48 hours

SAMPLE: $\mathrm{NaCl}$ in Upper Three Runs SPECIES: Ceriodaphnia dubia

\begin{tabular}{|l|c|c|c|c|}
\hline \multirow{2}{*}{ METHOD } & \multirow{2}{*}{ LC50 } & \multicolumn{3}{c|}{ CONFIDENCE LIMITS } \\
\cline { 3 - 5 } & & LOWER & UPPER & SPAN \\
\hline Binomial & 0.151 & 0.110 & 0.220 & 0.110 \\
\hline MAA & $* * * *$ & $* * * *$ & $* * * *$ & $* * * *$ \\
\hline Probit & $* * * *$ & $* * * *$ & $* * * *$ & $* * * *$ \\
\hline Spearman-Karber & 0.149 & 0.128 & 0.173 & 0.045 \\
\hline
\end{tabular}

**** $=$ Limit does not exist.

\section{TRIMMED SPEARMAN-KARBER SUMMARY}

Trim:

$0 \%$

LC50:

0.149

95\% Lower confidence: $\quad 0.128$

95\% Upper confidence: $\quad 0.173$

\section{BINOMIAL METHOD}

\begin{tabular}{|c|c|c|c|l|}
\hline $\begin{array}{c}\text { Concentration } \\
(\mathrm{g} / \mathrm{L})\end{array}$ & $\begin{array}{c}\text { Number } \\
\text { Exposed }\end{array}$ & $\begin{array}{c}\text { Number } \\
\text { Dead }\end{array}$ & $\begin{array}{c}\text { Percent } \\
\text { Dead }\end{array}$ & $\begin{array}{c}\text { Binomial } \\
\text { Probability (\%) }\end{array}$ \\
\hline 0.05 & 20 & 0 & 0 & $.9537 \mathrm{D}-04$ \\
\hline 0.11 & 20 & 3 & 15 & $.1288 \mathrm{D}-00$ \\
\hline 0.22 & 20 & 18 & 90 & $.2012 \mathrm{D}-01$ \\
\hline 0.44 & 20 & 20 & 100 & $.9537 \mathrm{D}-04$ \\
\hline 0.88 & 20 & 20 & 100 & $.9537 \mathrm{D}-04$ \\
\hline 1.32 & 20 & 20 & 100 & $.9537 \mathrm{D}-04$ \\
\hline
\end{tabular}

The binomial test shows that 0.11 and 0.22 can be statistically sound conservative 95 percent confidence limits since the actual confidence level associated with these limits is 99.8510 percent. An approximate LC50 for this data set is 0.151 


\section{RESULTS USING MOVING AVERAGE}

The moving average method cannot be used with this data set because no span which produces average angles bracketing 45 degrees also uses two percent dead between 0 and 100 percent.

\section{RESULTS CALCULATED BY PROBIT METHOD}

No convergence in 25 iterations. Probit method probably can not be use with this set of data. 
Summary of statistical analysis for the $D$. ambigua 48-hour acute test with sodium chloride in water collected from Upper Three Runs.

\section{CT-TOX MULTI-METHOD PROGRAM \\ Binomial, Moving average, Probit, and Spearman-Karber Methods}

\section{TEST SUMMARY}

DATE: 9-1-97

DURATION: 48 hours

SAMPLE: $\mathrm{NaCl}$ in Upper Three Runs SPECIES: Daphnia ambigua

\begin{tabular}{|l|c|c|c|c|}
\hline \multirow{2}{*}{ METHOD } & \multirow{2}{*}{ LC50 } & \multicolumn{3}{c|}{ CONFIDENCE LIMITS } \\
\cline { 3 - 5 } & & LOWER & UPPER & SPAN \\
\hline Binomial & 0.577 & 0.440 & 0.880 & 0.440 \\
\hline MAA & $* * * *$ & $* * * *$ & $* * * *$ & $* * * *$ \\
\hline Probit & $* * * *$ & $* * * *$ & $* * * *$ & $* * * *$ \\
\hline Spearman-Karber & 0.581 & 0.529 & 0.637 & 0.108 \\
\hline
\end{tabular}

**** $=$ Limit does not exist.

TRIMMED SPEARMAN-KARBER SUMMARY

Trim:

$0 \%$

LC50:

0.581

95\% Lower confidence: $\quad 0.529$

95\% Upper confidence: $\quad 0.637$

BINOMIAL METHOD

\begin{tabular}{|c|c|c|c|l|}
\hline $\begin{array}{c}\text { Concentration } \\
(\mathrm{g} / \mathrm{L})\end{array}$ & $\begin{array}{c}\text { Number } \\
\text { Exposed }\end{array}$ & $\begin{array}{c}\text { Number } \\
\text { Dead }\end{array}$ & $\begin{array}{c}\text { Percent } \\
\text { Dead }\end{array}$ & $\begin{array}{c}\text { Binomial } \\
\text { Probability (\%) }\end{array}$ \\
\hline 0.05 & 20 & 0 & 0 & $.9537 \mathrm{D}-04$ \\
\hline 0.11 & 20 & 0 & 0 & $.9537 \mathrm{D}-04$ \\
\hline 0.22 & 20 & 0 & 0 & $.9537 \mathrm{D}-04$ \\
\hline 0.44 & 20 & 2 & 10 & $.2012 \mathrm{D}-01$ \\
\hline 0.88 & 20 & 20 & 100 & $.9537 \mathrm{D}-04$ \\
\hline 1.32 & 20 & 20 & 100 & $.9537 \mathrm{D}-04$ \\
\hline
\end{tabular}

The binomial test shows that 0.44 and 0.88 can be statistically sound conservative 95 percent confidence limits since the actual confidence level associated with these limits is 99.9798 percent. An approximate LC50 for this data set is 0.577 . 
WHEN THERE ARE LESS THAN TWO CONCENTRATIONS AT

WHICH THE PERCENT DEAD IS BETWEEN 0 AND 100, NEITHER THE MOVING AVERAGE NOR THE PROBIT METHOD CAN GIVE ANY STATISTICALLY SOUND RESULTS. 
TEST:

Start Date:
Sodium chloride test in Upper Three Runs water for $C$. dubia 8/29/97

Initial Water Chemistry

\begin{tabular}{ccccccc}
\hline $\begin{array}{c}\text { Concentration } \\
(\mathrm{g} / \mathrm{L})\end{array}$ & $\begin{array}{c}\mathrm{DO} \\
(\mathrm{mg} / \mathrm{L})\end{array}$ & $\mathrm{pH}$ & $\begin{array}{c}\text { Temperature } \\
\left({ }^{\circ} \mathrm{C}\right)\end{array}$ & $\begin{array}{c}\text { Conductivity } \\
(\mathrm{ms} / \mathrm{cm})\end{array}$ & $\begin{array}{c}\text { Alkalinity } \\
\left(\mathrm{mg} / \mathrm{L} \text { as } \mathrm{CaCO}_{3}\right)\end{array}$ & $\begin{array}{c}\text { Hardness } \\
\left(\mathrm{mg} / \mathrm{L} \text { as } \mathrm{CaCO}_{3}\right)\end{array}$ \\
\hline Control & 8.35 & 6.55 & 25.0 & 0.014 & 4 & 10 \\
0.05 & 8.42 & 6.56 & 25.1 & 0.135 & & \\
0.11 & 8.46 & 6.58 & 25.2 & 0.254 & & \\
0.22 & 8.52 & 6.49 & 25.3 & 0.515 & & \\
0.44 & 8.36 & 6.53 & 25.2 & 1.000 & & \\
0.88 & 8.25 & 6.58 & 25.2 & 1.940 & & 8 \\
1.32 & 8.35 & 6.47 & 25.3 & 2.880 & 4 & 8 \\
\hline
\end{tabular}

24-Hour Readings

\begin{tabular}{cccc}
\hline $\begin{array}{c}\text { Concentration } \\
(\mathbf{g} / \mathbf{L})\end{array}$ & $\begin{array}{c}\mathbf{D O} \\
(\mathbf{m} \mathbf{g} / \mathbf{L})\end{array}$ & $\mathbf{p H}$ & $\begin{array}{c}\text { Temperature } \\
\left({ }^{\circ} \mathbf{C}\right)\end{array}$ \\
\hline Control & 8.15 & 6.47 & 24.5 \\
0.05 & 8.25 & 6.50 & 24.6 \\
0.11 & 8.32 & 6.52 & 24.5 \\
0.22 & 8.16 & 6.49 & 24.4 \\
0.44 & 8.19 & 6.53 & 24.7 \\
0.88 & 8.27 & 6.52 & 24.4 \\
1.32 & 8.35 & 5.46 & 24.5 \\
\hline
\end{tabular}

48-Hour Readings

\begin{tabular}{cccc}
\hline $\begin{array}{c}\text { Concentration } \\
(\mathrm{g} / \mathrm{L})\end{array}$ & $\begin{array}{c}\text { DO } \\
(\mathrm{mg} / \mathrm{L})\end{array}$ & $\mathbf{p H}$ & $\begin{array}{c}\text { Temperature } \\
\left({ }^{\circ} \mathrm{C}\right)\end{array}$ \\
\hline Control & 7.97 & 6.75 & 24.1 \\
0.05 & 8.12 & 6.62 & 24.4 \\
0.11 & 8.03 & 6.57 & 24.0 \\
0.22 & 8.16 & 6.52 & 24.0 \\
0.44 & 7.95 & 6.45 & 24.3 \\
0.88 & 8.34 & 6.33 & 24.2 \\
1.32 & 8.21 & 6.29 & 24.0 \\
\hline
\end{tabular}


TEST: $\quad$ Sodium chloride test in Upper Three Runs water for $D$. ambigua

Start Date: $\quad$ 8/29/97

Initial Water Chemistry

\begin{tabular}{|c|c|c|c|c|c|c|}
\hline $\begin{array}{c}\text { Concentration } \\
(\mathrm{g} / \mathrm{L})\end{array}$ & $\begin{array}{c}\mathrm{DO} \\
(\mathrm{mg} / \mathrm{L})\end{array}$ & $\mathbf{p H}$ & $\begin{array}{c}\text { Temperature } \\
\left({ }^{\circ} \mathrm{C}\right)\end{array}$ & $\begin{array}{c}\text { Conductivity } \\
\text { (ms/cm) }\end{array}$ & $\begin{array}{c}\text { Alkalinity } \\
\left(\mathrm{mg} / \mathrm{L} \text { as } \mathrm{CaCO}_{3}\right)\end{array}$ & $\begin{array}{c}\text { Hardness } \\
(\mathrm{mg} / \mathrm{L} \text { as } \mathrm{CaCO})\end{array}$ \\
\hline Control & 8.89 & 6.45 & 20.3 & 0.014 & 4 & 8 \\
\hline 0.05 & 9.01 & 6.43 & 20.1 & 0.135 & & \\
\hline 0.11 & 9.03 & 6.46 & 20.1 & 0.254 & & \\
\hline 0.22 & 8.96 & 6.47 & 20.1 & 0.515 & & \\
\hline 0.44 & 8.88 & 6.41 & 20.0 & 1.000 & & \\
\hline 0.88 & 8.99 & 6.46 & 20.0 & 1.940 & & \\
\hline 1.32 & 8.91 & 6.46 & 19.9 & 2.880 & 4 & 10 \\
\hline
\end{tabular}

24-Hour Readings

\begin{tabular}{cccc}
\hline $\begin{array}{c}\text { Concentration } \\
(\mathrm{g} / \mathrm{L})\end{array}$ & $\begin{array}{c}\text { DO } \\
(\mathbf{m g} / \mathrm{L})\end{array}$ & $\mathbf{p H}$ & $\begin{array}{c}\text { Temperature } \\
\left({ }^{\circ} \mathrm{C}\right)\end{array}$ \\
\hline Control & 9.10 & 6.52 & 20.6 \\
0.05 & 9.11 & 6.52 & 20.5 \\
0.11 & 8.96 & 6.53 & 20.6 \\
0.22 & 8.87 & 6.51 & 20.7 \\
0.44 & 9.13 & 6.49 & 21.0 \\
0.88 & 8.86 & 6.51 & 21.1 \\
1.32 & 8.95 & 6.56 & 20.9 \\
\hline
\end{tabular}

48-Hour Readings

\begin{tabular}{cccc}
\hline $\begin{array}{c}\text { Concentration } \\
(\mathrm{g} / \mathrm{L})\end{array}$ & $\begin{array}{c}\text { DO } \\
(\mathbf{m g} / \mathrm{L})\end{array}$ & pH & $\begin{array}{c}\text { Temperature } \\
\left({ }^{\circ} \mathrm{C}\right)\end{array}$ \\
\hline Control & 8.95 & 6.68 & 20.3 \\
0.05 & 8.92 & 6.56 & 20.4 \\
0.11 & 9.02 & 6.34 & 19.8 \\
0.22 & 8.76 & 6.50 & 20.0 \\
0.44 & 9.13 & 6.33 & 19.9 \\
0.88 & 9.05 & 6.23 & 19.8 \\
1.32 & 9.27 & 6.20 & 19.9 \\
\hline
\end{tabular}




\section{APPENDIX 3 C - ANALYTICAL CHEMISTRY DATA NaCI IN FOUR MILE BRANCH ACUTE}

Nominal and actual concentrations of sodium chloride in solutions used for acute toxicity testing. Actual concentrations of sodium were measured in the spiking solution, and final concentrations were calculated based on the amount of stock solutions spiked into the final dilution water. These values are applicable to the testing for both species. Values were determined by Trace Scan ICP.

\begin{tabular}{|c|c|c|c|c|}
\hline $\begin{array}{c}\text { Nominal NaC } \\
\text { Concentration } \\
\text { in the Test } \\
\begin{array}{c}\text { Solution } \\
(\mathrm{g} / \mathrm{L})\end{array}\end{array}$ & $\begin{array}{c}\text { NaCl } \\
\text { Concentration } \\
\text { in the Spiking } \\
\text { Solution } \\
(\mathrm{g} / \mathrm{L})^{\mathbf{1}}\end{array}$ & $\begin{array}{c}\text { Amount of } \\
\text { Spiking } \\
\text { Solution } \\
\text { Used } \\
(\mathbf{m L})\end{array}$ & $\begin{array}{c}\text { Final } \\
\text { Volume of } \\
\text { Test } \\
\text { Solution } \\
(\mathrm{mL})\end{array}$ & $\begin{array}{c}\text { Actual } \\
\text { Concentration } \\
\text { of NaCl in } \\
\text { Test Solution } \\
(\mathrm{g} / \mathrm{L})\end{array}$ \\
\hline 0.125 & 89.4 & 0.625 & 500 & 0.11 \\
\hline 0.25 & 89.4 & 1.25 & 500 & 0.22 \\
\hline 0.5 & 89.4 & 2.5 & 500 & 0.45 \\
\hline 1.0 & 89.4 & 5.0 & 500 & 0.89 \\
\hline 1.5 & 89.4 & 7.5 & 500 & 1.34 \\
\hline 2.0 & 89.4 & 12.0 & 600 & 1.79 \\
\hline
\end{tabular}

${ }^{1}$ The measured sodium concentration for the spiking solution in Four Mile Branch was $35.1 \mathrm{~g} / \mathrm{L}$. The sodium chloride concentration of $89.4 \mathrm{~g} / \mathrm{L}$ was calculated using the following formula: $[\mathrm{NaCl}]=([\mathrm{Na}] / 22.9) * 58.35$. 


\section{APPENDIX 3 C}

Forty-eight hour mortality observations on $C$. dubia in the Four Mile Branch sodium chloride toxicity test.

\begin{tabular}{|c|cc|cc|cc|}
\hline $\begin{array}{c}\text { Sodium Chloride } \\
\text { Concentration } \\
(\mathrm{g} / \mathrm{L})\end{array}$ & \multicolumn{4}{|c|}{ Replicate } & \multicolumn{2}{c|}{ Total } \\
& \multicolumn{2}{|c|}{1} & \multicolumn{2}{|c|}{2} & & \\
& dead alive & dead alive & dead & alive \\
\hline Control & 0 & 10 & 0 & 10 & 0 & 20 \\
\hline 0.11 & 0 & 10 & 0 & 10 & 0 & 20 \\
\hline 0.22 & 0 & 10 & 0 & 10 & 0 & 20 \\
\hline 0.45 & 7 & 3 & 9 & 1 & 16 & 4 \\
\hline 0.89 & 9 & 1 & 10 & 0 & 19 & 1 \\
\hline 1.34 & 10 & 0 & 10 & 0 & 20 & 0 \\
\hline 1.79 & 10 & 0 & 10 & 0 & 20 & 0 \\
\hline
\end{tabular}

48-hour $\mathrm{LC}_{50}=0.37 \mathrm{~g} / \mathrm{L}(95 \%$ confidence limits $=0.33-0.43 \mathrm{~g} / \mathrm{L})$.

Forty-eight hour mortality observations on D. ambigua in the Four Mile Branch sodium chloride toxicity test.

\begin{tabular}{|c|cc|cc|cc|}
\hline $\begin{array}{c}\text { Sodium Chloride } \\
\text { Concentration } \\
(\mathrm{g} / \mathrm{L})\end{array}$ & \multicolumn{4}{|c|}{ Replicate } & \multicolumn{2}{|c|}{ Total } \\
& \multicolumn{2}{|c|}{1} & \multicolumn{2}{c|}{2} & & \\
& dead alive & dead & alive & dead alive \\
\hline Control & 0 & 10 & 0 & 10 & 0 & 20 \\
\hline 0.11 & 0 & 10 & 0 & 10 & 0 & 20 \\
\hline 0.22 & 0 & 10 & 0 & 10 & 0 & 20 \\
\hline 0.45 & 0 & 10 & 0 & 10 & 0 & 20 \\
\hline 0.89 & 10 & 0 & 10 & 0 & 20 & 0 \\
\hline 1.34 & 10 & 0 & 10 & 0 & 20 & 0 \\
\hline 1.79 & 10 & 0 & 10 & 0 & 20 & 0 \\
\hline
\end{tabular}

48-hour $\mathrm{LC}_{50}=0.63 \mathrm{~g} / \mathrm{L}$ (95\% confidence limits $\left.=0.45-0.89 \mathrm{~g} / \mathrm{L}\right)$. 
Summary of statistical analysis for the $C$. dubia 48-hour acute test with sodium chloride in water collected from Four Mile Branch.

\section{CT-TOX MULTI-METHOD PROGRAM}

Binomial, Moving average, Probit, and Spearman-Karber Methods

\section{TEST SUMMARY}

DATE: 9-1-97

DURATION: 48 hours

SAMPLE: $\mathrm{NaCl}$ in Four Mile

SPECIES: Ceriodaphnia dubia

\begin{tabular}{|l|c|c|c|c|}
\hline \multirow{2}{*}{ METHOD } & \multirow{2}{*}{ LC50 } & \multicolumn{3}{|c|}{ CONFIDENCE LIMTS } \\
\cline { 3 - 5 } & & LOWER & UPPER & SPAN \\
\hline Binomial & 0.360 & 0.220 & 0.450 & 0.230 \\
\hline MAA & $* * * *$ & $* * * *$ & $* * * *$ & $* * * *$ \\
\hline Probit & $* * * *$ & $* * * *$ & $* * * *$ & $* * * *$ \\
\hline Spearman-Karber & 0.372 & 0.325 & 0.426 & 0.101 \\
\hline
\end{tabular}

${ }^{* * * *}=$ Limit does not exist.

\section{TRIMMED SPEARMAN-KARBER SUMMARY}

Trim:

$0 \%$

LC50:

0.372

95\% Lower confidence: $\quad 0.325$

95\% Upper confidence: $\quad 0.426$

\section{BINOMIAL METHOD}

\begin{tabular}{|c|c|c|c|l|}
\hline $\begin{array}{c}\text { Concentration } \\
(\mathrm{g} / \mathrm{L})\end{array}$ & $\begin{array}{c}\text { Number } \\
\text { Exposed }\end{array}$ & $\begin{array}{c}\text { Number } \\
\text { Dead }\end{array}$ & $\begin{array}{c}\text { Percent } \\
\text { Dead }\end{array}$ & $\begin{array}{c}\text { Binomial } \\
\text { Probability (\%) }\end{array}$ \\
\hline 0.11 & 20 & 0 & 0 & $.9537 \mathrm{D}-04$ \\
\hline 0.22 & 20 & 0 & 0 & $.9537 \mathrm{D}-04$ \\
\hline 0.45 & 20 & 16 & 80 & $.5909 \mathrm{D}+00$ \\
\hline 0.89 & 20 & 19 & 95 & $.2003 \mathrm{D}-02$ \\
\hline 1.34 & 20 & 20 & 100 & $.9537 \mathrm{D}-04$ \\
\hline 1.79 & 20 & 20 & 100 & $.9537 \mathrm{D}-04$ \\
\hline
\end{tabular}

The binomial test shows that 0.22 and 0.45 can be statistically sound conservative 95 percent confidence limits since the actual confidence level associated with these limits is 99.4090 percent. An approximate LC50 for this data set is $\mathbf{0 . 3 6 0}$. 


\section{RESULTS USING MOVING AVERAGE}

The moving average method cannot be used with this data set because no span which produces average angles bracketing $\mathbf{4 5}$ degrees also uses two percent dead between 0 and 100 percent.

\section{RESULTS CALCULATED BY PROBIT METHOD}

No convergence in 25 iterations. Probit method probably can not be use with this set of data. 
Summary of statistical analysis for the $D$. ambigua 48 -hour acute test with sodium chloride in water collected from Four Mile Branch.

\section{CT-TOX MULTI-METHOD PROGRAM \\ Binomial, Moving average, Probit, and Spearman-Karber Methods}

TEST SUMMARY

DATE: $9-1-97$

DURATION: 48 hours

SAMPLE: $\mathrm{NaCl}$ in Four Mile Branch SPECIES: Daphnia ambigua

\begin{tabular}{|l|c|c|c|c|}
\hline \multirow{2}{*}{ METHOD } & \multirow{2}{*}{ LC50 } & \multicolumn{3}{c|}{ CONFIDENCE LIMITS } \\
\cline { 3 - 5 } & & LOWER & UPPER & SPAN \\
\hline Binomial & 0.633 & 0.450 & 0.890 & 0.440 \\
\hline MAA & $* * * *$ & $* * * *$ & $* * * *$ & $* * * *$ \\
\hline Probit & $* * * *$ & $* * * *$ & $* * * *$ & $* * * *$ \\
\hline Spearman-Karber & 0.633 & $* * * *$ & $* * * *$ & $* * * *$ \\
\hline
\end{tabular}

**** $=$ Limit does not exist.

TRIMMED SPEARMAN-KARBER SUMMARY

Trim: $\quad 0 \%$

LC50: $\quad 0.633$

95\% confidence limits are unreliable

BINOMIAL METHOD

\begin{tabular}{|c|c|c|c|l|}
\hline $\begin{array}{c}\text { Concentration } \\
(\mathrm{g} / \mathrm{L})\end{array}$ & $\begin{array}{c}\text { Number } \\
\text { Exposed }\end{array}$ & $\begin{array}{c}\text { Number } \\
\text { Dead }\end{array}$ & $\begin{array}{c}\text { Percent } \\
\text { Dead }\end{array}$ & $\begin{array}{c}\text { Binomial } \\
\text { Probability (\%) }\end{array}$ \\
\hline 0.11 & 20 & 0 & 0 & $.9537 \mathrm{D}-04$ \\
\hline 0.22 & 20 & 0 & 0 & $.9537 \mathrm{D}-04$ \\
\hline 0.45 & 20 & 0 & 0 & $.9537 \mathrm{D}-04$ \\
\hline 0.89 & 20 & 20 & 100 & $.9537 \mathrm{D}-04$ \\
\hline 1.34 & 20 & 20 & 100 & $.9537 \mathrm{D}-04$ \\
\hline 1.79 & 20 & 20 & 100 & $.9537 \mathrm{D}-04$ \\
\hline
\end{tabular}

The binomial test shows that 0.45 and 0.89 can be statistically sound conservative 95 percent confidence limits since the actual confidence level associated with these limits is 99.9998 percent. An approximate LC50 for this data set is $\mathbf{0 . 6 3 3 .}$ 
WHEN THERE ARE LESS THAN TWO CONCENTRATIONS AT WHICH THE PERCENT DEAD IS BETWEEN 0 AND 100, NEITHER THE MOVING AVERAGE NOR THE PROBIT METHOD CAN GIVE ANY STATISTICALLY SOUND RESULTS.

D. ambigua $\mathrm{NaCl}$ acute in Four Mile Branch 
TEST: $\quad$ Sodium chloride test in Four Mile Branch water with $C$, dubia

Start Date: $\quad$ 9/1/97

Initial Water Chemistry

\begin{tabular}{|c|c|c|c|c|c|c|}
\hline $\begin{array}{c}\text { Concentration } \\
(\mathrm{g} / \mathrm{L})\end{array}$ & $\begin{array}{c}\text { DO } \\
(\mathrm{mg} / \mathrm{L})\end{array}$ & pH & $\begin{array}{c}\text { Temperature } \\
\left({ }^{\circ} \mathrm{C}\right)\end{array}$ & $\begin{array}{l}\text { Conductivity } \\
\text { (ms/cm) }\end{array}$ & $\begin{array}{c}\text { Alkalinity } \\
\left(\mathrm{mg} / \mathrm{L} \text { as } \mathrm{CaCO}_{3}\right)\end{array}$ & $\begin{array}{c}\text { Hardness } \\
\left.\text { (mg/L as } \mathrm{CaCO}_{3}\right)\end{array}$ \\
\hline Control & 8.11 & 6.40 & 24.1 & 0.026 & 6 & 8 \\
\hline 0.11 & 8.26 & 6.45 & 24.5 & 0.260 & & \\
\hline 0.22 & 8.35 & 6.35 & 24.3 & 0.476 & & \\
\hline 0.45 & 8.64 & 6.44 & 24.4 & 0.847 & & \\
\hline 0.89 & 8.44 & 6.47 & 24.3 & 1.850 & & \\
\hline 1.34 & 8.15 & 6.40 & 24.1 & 2.830 & & \\
\hline 1.79 & 8.36 & 6.39 & 24.0 & 2.740 & 6 & 8 \\
\hline
\end{tabular}

24-Hour Readings

\begin{tabular}{cccc}
\hline $\begin{array}{c}\text { Concentration } \\
(\mathrm{g} / \mathrm{L})\end{array}$ & $\begin{array}{c}\text { DO } \\
(\mathrm{mg} / \mathrm{L})\end{array}$ & $\mathrm{pH}$ & $\begin{array}{c}\text { Temperature } \\
\left({ }^{\circ} \mathrm{C}\right)\end{array}$ \\
\hline Control & 7.95 & 6.37 & 24.2 \\
0.11 & 7.89 & 6.43 & 24.1 \\
0.22 & 7.82 & 6.42 & 24.2 \\
0.45 & 8.12 & 6.39 & 24.4 \\
0.89 & 8.06 & 6.32 & 24.5 \\
1.34 & 8.11 & 6.32 & 24.1 \\
1.79 & 7.96 & 6.40 & 24.3 \\
\hline
\end{tabular}

48-Hour Readings

\begin{tabular}{cccc}
\hline $\begin{array}{c}\text { Concentration } \\
(\mathrm{g} / \mathrm{L})\end{array}$ & $\begin{array}{c}\text { DO } \\
(\mathbf{m g} / \mathrm{L})\end{array}$ & $\mathbf{p H}$ & $\begin{array}{c}\text { Temperature } \\
\left({ }^{\circ} \mathrm{C}\right)\end{array}$ \\
\hline Control & $\mathbf{8 . 1 4}$ & 7.03 & 24.8 \\
0.11 & $\mathbf{8 . 0 8}$ & 6.88 & 24.1 \\
0.22 & $\mathbf{8 . 2 7}$ & 6.70 & 24.1 \\
0.45 & $\mathbf{8 . 0 2}$ & 6.63 & 24.4 \\
0.89 & 8.04 & 6.51 & 24.0 \\
1.34 & 7.86 & 6.42 & 24.2 \\
1.79 & $\mathbf{8 . 2 1}$ & 6.39 & 24.4 \\
\hline
\end{tabular}


TEST: $\quad$ Sodium chloride test in Four Mile Branch water with D. ambigua

Start Date: $\quad$ 9/1/97

Initial Water Chemistry

\begin{tabular}{ccccccc}
\hline $\begin{array}{c}\text { Concentration } \\
(\mathbf{g} / \mathbf{L})\end{array}$ & $\begin{array}{c}\text { DO } \\
(\mathbf{m g} / \mathbf{L})\end{array}$ & $\mathbf{p H}$ & $\begin{array}{c}\text { Temperature } \\
\left({ }^{\circ} \mathbf{C}\right)\end{array}$ & $\begin{array}{c}\text { Conductivity } \\
(\mathbf{m s} / \mathbf{c m})\end{array}$ & $\begin{array}{c}\text { Alkalinity } \\
\left(\mathbf{m g} / \mathbf{L} \text { as } \mathbf{C a C O}_{\mathbf{3}}\right)\end{array}$ & $\begin{array}{c}\text { Hardness } \\
\left(\mathbf{m g} / \mathbf{L} \text { as } \mathbf{C a C O}_{\mathbf{3}}\right)\end{array}$ \\
\hline Control & 8.87 & 6.35 & 21.1 & 0.026 & 6 & 8 \\
0.11 & 8.89 & 6.35 & 21.0 & 0.260 & & \\
0.22 & 8.71 & 6.39 & 21.4 & 0.476 & & \\
0.45 & 8.77 & 6.42 & 21.3 & 0.847 & & \\
0.89 & 8.65 & 6.40 & 21.1 & 1.850 & & \\
1.34 & 8.66 & 6.37 & 21.1 & 2.830 & 6 & 8 \\
1.79 & 8.76 & 6.38 & 21.1 & 2.740 & & \\
\hline
\end{tabular}

\section{4-Hour Readings}

\begin{tabular}{cccc}
\hline $\begin{array}{c}\text { Concentration } \\
(\mathrm{g} / \mathrm{L})\end{array}$ & $\begin{array}{c}\text { DO } \\
(\mathrm{mg} / \mathrm{L})\end{array}$ & $\mathrm{pH}$ & $\begin{array}{c}\text { Temperature } \\
\left({ }^{\circ} \mathrm{C}\right)\end{array}$ \\
\hline Control & 8.54 & 6.45 & 21.0 \\
0.11 & 8.56 & 6.46 & 20.9 \\
0.22 & 8.49 & 6.42 & 20.8 \\
0.45 & 8.46 & 6.48 & 20.8 \\
0.89 & 8.48 & 6.42 & 21.0 \\
1.34 & 8.44 & 6.42 & 21.0 \\
1.79 & 8.44 & 6.44 & 20.8 \\
\hline
\end{tabular}

48-Hour Readings

\begin{tabular}{cccc}
\hline $\begin{array}{c}\text { Concentration } \\
(\mathrm{g} / \mathrm{L})\end{array}$ & $\begin{array}{c}\text { DO } \\
(\mathbf{m g} / \mathrm{L})\end{array}$ & $\mathbf{p H}$ & $\begin{array}{c}\text { Temperature } \\
\left({ }^{\circ} \mathrm{C}\right)\end{array}$ \\
\hline Control & $\mathbf{8 . 8 4}$ & 6.65 & 19.7 \\
0.11 & 9.11 & 6.56 & 19.8 \\
0.22 & $\mathbf{8 . 7 8}$ & 6.46 & 19.9 \\
0.45 & 9.03 & 6.42 & 19.5 \\
0.89 & 9.00 & 6.38 & 19.7 \\
1.34 & 9.01 & 6.30 & 19.9 \\
1.79 & $\mathbf{8 . 9 1}$ & 6.28 & 19.8 \\
\hline
\end{tabular}

